


\section{Distribution of CAP pillar 1 payments to farmers in the EU}

Ida Terluin and David Verhoog

This study was carried out by Wageningen Economic Research and was commissioned and financed by the Dutch Ministry of Agriculture, Nature and Food Quality within the context of the 'CAP' research theme of the Policy Support Research (project number BO-20-017-044-LEI)

Wageningen Economic Research

Wageningen, March 2018

REPORT

2018-039b

ISBN 978-94-6343-266-5 
Terluin, I.J. and A.D. Verhoog, 2018. Distribution of CAP pillar 1 payments to farmers in the EU. Wageningen, Wageningen Economic Research, Report 2018-039b. 62 pp.; 9 fig.; 4 tab.; 9 ref.

During this study, an analysis was conducted of the distribution of direct payments from the first pillar of the Common Agricultural Policy (CAP) to farmers in the EU28. This distribution has been shown to be uneven: in $2015,81 \%$ of EU farmers received $20 \%$ of the payments. Farms that receive few payments are usually smaller than those that receive higher payments. The uneven distribution of direct payments is caused by the fact that the group of farmers with small farms in the EU28 is much larger than the group with large farms.

This report can be downloaded for free at https://doi.org/10.18174/444994 or at www. wur.eu/economic-research (under Wageningen Economic Research publications).

(C) 2018 Wageningen Economic Research

P.O. Box 29703, 2502 LS The Hague, The Netherlands, T +31 (0)70 33583 30,

E communications.ssg@wur.nl, http://www.wur.eu/economic-research. Wageningen Economic Research is part of Wageningen University \& Research.

\section{(cc) BY-NC}

For its reports, Wageningen Economic Research utilises a Creative Commons Attributions 3.0 Netherlands license.

(c) Wageningen Economic Research, part of Stichting Wageningen Research, 2018

The user may reproduce, distribute and share this work and make derivative works from it. Material by third parties which is used in the work and which are subject to intellectual property rights may not be used without prior permission from the relevant third party. The user must attribute the work by stating the name indicated by the author or licensor but may not do this in such a way as to create the impression that the author/licensor endorses the use of the work or the work of the user. The user may not use the work for commercial purposes.

Wageningen Economic Research accepts no liability for any damage resulting from the use of the results of this study or the application of the advice contained in it.

Wageningen Economic Research is ISO 9001:2008 certified.

Wageningen Economic Research Report 2018-039 | Project code 2282500250

Cover photo: Shutterstock 


\section{Contents}

Preface

Summary

S.1 In 2015, $81 \%$ of the farmers in the EU28 received $20 \%$ of the direct payments. The group of farmers that received $20 \%$ of the direct payments ranged from $54 \%$ in Luxembourg to $93 \%$ in Slovakia

S.2 Most farmers receive less than $€ 5,000$ in payments 7

$\begin{array}{lll}\text { S.3 Research Design } & 7\end{array}$

1

$\begin{array}{ll}\text { Introduction } & 8\end{array}$

2

$\begin{array}{lr}\text { Approach } & 9\end{array}$

3

Results

3.1 Introduction $\quad 11$

3.2 Distribution of direct payments to farmers by payment amount 11

3.3 Distribution of direct payments to farmers by economic size class 18

3.4 Direct payments as a percentage of the agricultural income per farming type 19

References and websites

Appendix 1 Fictitious distribution of direct payments to farms in EU member countries based on a uniform hectare payment

Appendix 2 Direct payments from the first pillar of the CAP as a percentage of income per farming type in EU member countries, 2015 



\section{Preface}

In its communication "The Future of Food and Farming" (COM(2017) 713 def), the European Commission outlined the fulfilment of the Common Agricultural Policy (CAP) after 2020. In this communication, the European Commission states that it considers direct payments to be an essential component. These payments will partially serve to bridge the gap between income in the agricultural sector and incomes in other economic sectors. In this way, they form an important income safety net which contributes to farmers everywhere in the EU being able to conduct agricultural activities, even in areas with natural constraints. The importance that is placed on stimulating reasonable incomes in the agricultural sector in the EU was also established in the Treaty of Lisbon.

Each year, the European Commission publishes a report on the distribution of direct payments to farmers in the EU from the first pillar of the CAP. This has shown that the distribution is uneven: roughly $80 \%$ of farmers receive $20 \%$ of the payments. That means that the remaining $20 \%$ of farmers receive a considerable share: $80 \%$ of the payments. The uneven distribution raises the question of whether, according to the current way of implementation, the direct payments are actually being received by the farms that need them in order to achieve a reasonable income from agricultural activities. To properly support the standpoints in the EU-wide discussion of the future of CAP Pillar 1 payments, the Dutch Ministry of Agriculture, Nature, and Food Quality requires insight into the distribution of current direct payments to farmers in EU member countries. For this reason, the Dutch Ministry of Agriculture, Nature, and Food Quality has commissioned Wageningen Economic Research to conduct an analysis of the distribution of direct payments to farmers in the EU28 in 2015 - the year for which the most recent data is available - and to check what differences exist between the member countries and what the structural characteristics are of farmsfarms that receive more/fewer payments.

The study was conducted by Dr I.J. Terluin (project manager) and Mr A.D. Verhoog of Wageningen Economic Research. Wageningen Economic Research gratefully acknowledges the support and collaboration of Dr R.P. Baayen, Dr J.L.M. Boogerd, Mr L.J.T.C. Lantain, Mr H.J.A. Ruissen, and Mr F. Vroegop from the Dutch Ministry of Agriculture, Nature, and Food Quality.

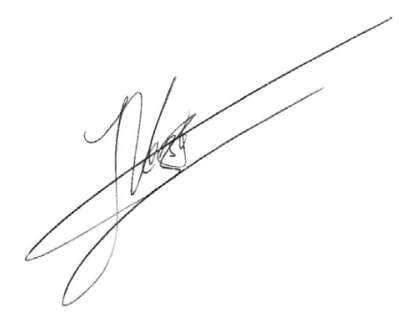

Prof.dr.ir. J.G.A.J . (J ack) van der Vorst

General Director Social Sciences Group (SSG)

Wageningen University \& Research 


\section{Summary}

\section{S.1 In 2015, 81\% of the farmers in the EU28 received $20 \%$ of the direct payments. The group of farmers that received $20 \%$ of the direct payments ranged from $54 \%$ in Luxembourg to $93 \%$ in Slovakia}

The distribution of CAP Pillar 1 payments was shown to be uneven: in 2015 (the year for which the most recent data are available), $81 \%$ of the farmers in the EU28 received $20 \%$ of the direct payments. Therefore, there is a large group of farmers in the EU28 who receive a significantly small amount of direct payments and a small group of farmers who receive a large amount of payments. The size of the group of farmers who receive $20 \%$ of the direct payments varies substantially between member countries: this group is smallest in Luxembourg (54\%) and largest in Slovakia (93\%) (Figure S.1). This means that the distribution in Luxembourg is less uneven than the EU28 average, while in Slovakia, it is more uneven. See Section 3.2.

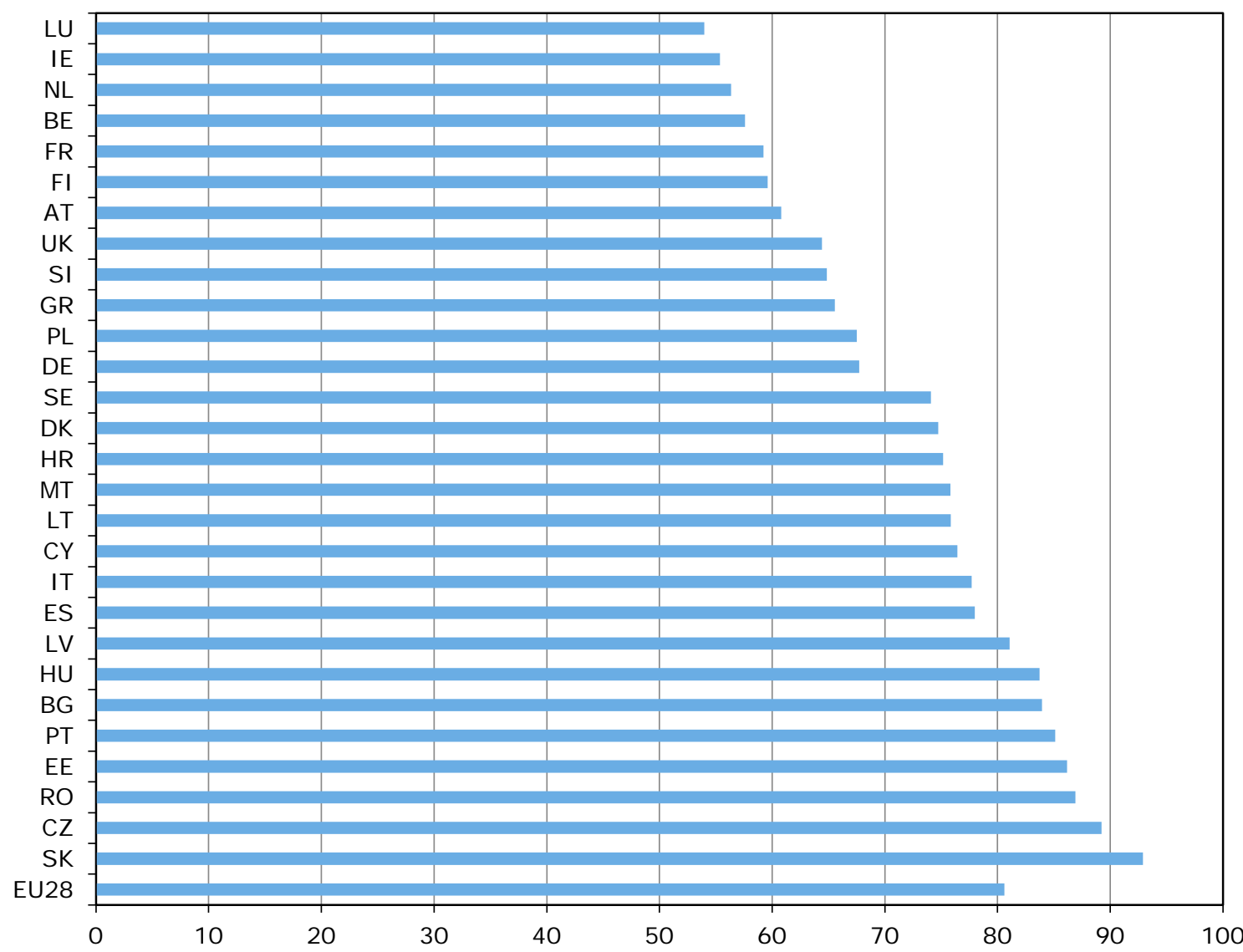

Figure S.1 The percentage of farmers in each EU member country that receives $20 \%$ of CAP Pillar 1 payments, 2015 (\% of total number of farmers)

Source: EC (2017b); adaptation by Wageningen Economic Research. 


\section{Uneven distribution of payments is partially related to country-specific elements and a difference in farm size}

The direct payments are partly based on the number of hectares per farm and partly based on country-specific elements such as historical references and coupled payments. As long as the CAP offers different options to member countries for the way in which payments are granted, it can be expected that there will be differences between member countries in the distribution of the payments to farmers due to the use of specific options. However, an unequal distribution of payments to farmers would also result if member countries are only permitted to grant them as a uniform hectare payment. If that were the case, then roughly $86 \%$ of farmers in the EU28 would receive $20 \%$ of the payments, which is an even more uneven distribution than was the actual case in 2015 . This uneven distribution is related to the fact that the group of farmers in the EU28 with small farms is much larger than those with large farms. An equal distribution of payments to farmers can only occur under a uniform hectare payment if every farm in the EU28 had the same number of hectares. The current distribution of farms in the size classes by hectares deviates strongly from that situation. See Section 3.2.

\section{S.2 Most farmers receive less than $€ 5,000$ in payments}

Roughly three quarters of farmers in the EU28 received less than €5,000 of direct payments in 2015. Among those farmers, one quarter received less than $€ 500$, one quarter received between $€ 500$ and $€ 1,250$, and one quarter received between $€ 1,250$ and $€ 5,000$. Roughly 16,000 farmers in the EU $(0.2 \%$ of the total number of farmers) received more than $€ 150,000$ in 2015 . See Section 3.2.

\section{The direct payments as a percentage of agricultural income varies widely}

The direct payments as a share of family farm income per family work unit in the EU28 is significant and varies from a third for the lower income classes to the half in the higher income classes. Therefore, as farm income increases, the farmers receive higher direct payments on average. The direct payments as a share of income for the different farming types varies substantially from the EU average. In 2015, the direct payments as a percentage of family farm income per family work unit at specialist cattle farms and farms specialising in cereals, oilseed, and protein crops were over $100 \%$, the percentage for farms producing other field crops, dairy farms, and sheep/goat farms was around $70 \%$, and the percentage for intensive livestock farms stood at roughly $30 \%$. Since agricultural incomes can fluctuate significantly from year to year, the direct payments as a percentage of agricultural income differ annually as well. See Section 3.4.

\section{S.3 Research Design}

Within the context of the first pillar of the CAP, farmers receive direct payments. These are meant to generate reasonable incomes in the agricultural sector. In this study, it was examined how direct payments were distributed to farmers in 2015 and what differences were present between the member countries. See Chapter 1.

The study is based on calculations using data from three sources: the European Commission (EC) regarding the number of beneficiaries of payments from the first pillar, the Farm Accountancy Data Network (FADN), and the Farm Structure Survey (FSS). See Chapter 2. 


\section{Introduction}

In the discussion on modernisation and simplification of the Common Agricultural Policy (CAP), supporting family farms plays an important role. The Treaty of Lisbon (Art. 39) requires the EU and its member states to provide a reasonable income for agricultural workers, in order to partially bridge the gap between agricultural income and incomes in other economic sectors. In its initial stages, the CAP was primarily implemented through price support. Beginning in the 1990s, the price support was progressively replaced by direct payments. In the 2014-2020 period, payments per hectare and coupled payments for specific products went into use in the CAP to achieve the goal of reasonable incomes for agricultural workers. These direct payments and coupled payments are made through the first pillar of the CAP.

In the EU-wide discussion regarding the future of CAP income support, the intended target group is the family farm. The question is whether the direct payments are actually ending up in the hands of that group in practice, because the distribution of first-pillar payments to farms has been shown to be uneven (EC, 2016 and 2017b; Matthews, 2016): 20\% of businesses in the EU28 receive roughly 80\% of the payments. Since the payments are partially based on the number of hectares per farm, farms with many hectares receive more payments than those with fewer. By definition, this leads to an uneven distribution of payments to businesses. Another issue with the current direct payment scheme is that it has an upwards pressure on the land price. Since some of the landowners are not from the agricultural sector, this leads to an outflow of capital from the agricultural sector.

The uneven distribution raises the question of whether, according to the current way of implementation, the direct payments are actually being received by farmers that need them in order to achieve a reasonable income from the agricultural sector. To properly support the standpoints in the EU-wide discussion of the future of direct payments in the first pillar of the CAP, the Dutch Ministry of Agriculture, Nature, and Food Quality requires insight into the distribution of current payments to farms in EU member countries from the first pillar of the CAP and the differences in distribution between member countries.

Research questions

In this study the following questions are addressed:

- How are CAP Pillar 1 payments distributed to farmers in 2015 and what differences exist between countries?

- How do the differences in the distribution of direct payments between member countries come about?

- What are the structural characteristics of businesses that receive few/many payments?

- What is the percentage of farms in each member country that receive no payments at all?

- What is the amount of payments as a percentage of income per worker by farm size and type for each EU member country?

Structure of this study

The structure of this study is as follows. Chapter 2 describes the approach to the research. Chapter 3 discusses the results. In it, we first discuss the distribution of direct payments to farmers by the amount of the payments received and by economic size class of the farms. Afterwards, we shift our focus to the direct payments as a percentage of agricultural income. In the last chapter, we draw several conclusions. 


\section{Approach}

We used data from three sources for our approach to the study: the European Commission (EC) regarding the number of beneficiaries of payments from the first pillar, the Farm Accountancy Data Network (FADN), and the Farm Structure Survey (FSS). We also indicate which calculations we performed to determine the distribution of payments to farmers by the economic size class of the farms and the fictitious distribution of payments based on a uniform hectare payment in the EU.

EC data: the distribution of payments to farmers by payment category

Each year, the EC publishes a report on the number of recipients ('beneficiaries') of payments from the first pillar, in which they divide the recipients according to the category of the payments received. They are divided into 15 classes, the lowest being $€ 0-500$ and the largest being more than $€ 500,000$. The most recent data available is for the 2016 financial year 1 (EC, 2017b). This concerns the payments from the first pillar during the 2015 calendar year, in which the new way of implementation of the direct payments of the 2014-2020 CAP was first applied. Using EC data for the 2016 financial year, the following things can be calculated: the number of farmers who received $20 \%$ of the direct payments in 2015 , how many farmers received no payments at all, and how many farmers received more than $€ 150,000$ in payments.

FADN: distribution of payments to farmers the economic size class of the farm Matthews (2016) applied an approach to the distribution of direct payments from the first pillar to farms in which he divided the farms up into economic size classes. Using this method, the direct payments as a percentage of agricultural income can be calculated. Since EC data does not contain any information on economic size class, the EC data was linked to the data from the FADN. Matthews performed his calculations for the 2013 calendar year, so he used data for the direct payments from the 2014 financial year (EC, 2015) and FADN data for the 2013 calendar year. We performed the same calculations as Matthews, but we used the direct payments from the 2016 financial year (EC, 2017b) and the FADN for the 2015 calendar year. Since the FADN has data for 4.7 million commercial farms in the EU and the EC (EC, 2017b) data is based on 6.7 million payment recipients, linking the two data series required several assumptions. Just as Matthews (2016) did, we performed a calculation of the distribution of direct payments from the first pillar by economic size class for the 2015 calendar year using the following steps and assumptions:

1. We assumed that the 2 million farmers who were present in EC data, but not in FADN data were small farms that received few direct payments. The group of farmers that received less than $€ 500$ according to the EC data ( 1.8 million farmers) is a bit smaller than the figure of 2 million.

2. The FADN distinguishes the following six economic size classes: $(1) € 2,000-8,000 ;(2) € 8,000$ 25,000 ; (3) €5,000-50,000; (4) €50,000-100,000; (5) €100,000-500,000; (6) >=€500,000. We added a economic size class of $<€ 2,000$ to this set and assumed that it contained the 1.8 million farmers from the EC data who received less than $€ 500$.

3. For the average farm in each of the economic classes, the FADN provides information on the amount of payments received from the first pillar and the income of the farm. It turned out that the direct payments in the economic size class $€ 2,000-8,000$ amounts to roughly one third of the income from the business. We superimposed this relationship onto the economic size class $<€ 2,000$.

4. According to the EC data, 1.8 million farmers ( who received less than $€ 500$ each) received a combined total of $€ 558$ million. If the payments amount to one third of agricultural income (step 3 ), then the combined total income of the economic size class $<€ 2,000$ comes to $€ 1.675$ million ( 3 $x € 558$ million). For each of those 1.8 million farms in that class, this amounts to an agricultural income of $€ 936$ and an average amount of $€ 312$ in received payments from the first pillar.

5. In order to draw a comparison with the distribution of direct payments from the first pillar based on the EC data, we converted both the 15 recipient categories from the EC data (2107b) and the

\footnotetext{
${ }^{1}$ Direct payments for calendar year $\mathrm{N}$ are paid out in fiscal year $\mathrm{N}+1$. Fiscal year $\mathrm{N}+1$ begins on 16 October of year $\mathrm{N}$ and ends on 15 October in year $\mathrm{N}+1$. Therefore, the 2016 fiscal year concerns the payments from 2015.
} 
7 economic size classes from the FADN data into 10 income deciles. In this way, it was easy to read how large the payments were in each decile.

FSS: fictitious distribution of direct payments based on an average hectare payment Using the Farm Structure Survey (FSS) as a basis, an analysis was conducted of farms according to farm size in hectares for each member country. This enabled the distribution of farms across the size classes in hectares to be visualised. The most recent FSS for which data is available was conducted in 2013. We used the number of 2013 farms as a proxy for the number in 2015. Next, we created a fictitious distribution of direct payments to farms in 2015 by assuming an average direct payment per hectare for each member country. We calculated the average direct payment per hectare by dividing the 2015 national envelope for each member country by the number of hectares of agricultural area of that member country. The fictitious distribution is only equal to the actual distribution if all farms in a member country were to receive a uniform payment for all hectares. In practice, the fictitious distribution generally approaches reality, because member countries use a portion of the national envelope to make additional payments to young farmers, payments to areas with natural constraints, coupled payments, etc. and several member countries provide direct payments based on a historical reference. 


\section{Results}

\subsection{Introduction}

In Section 3.2, we discuss the distribution of direct payments to farmers based on the payment amount received. We also talk about how that distribution would change if a uniform hectare payment were to be used. Attention is also given to the number of farmers that receive a small or large amount of direct payments. In Sections 3.3 and 3.4, we link the payments received with the agricultural incomes. In Section 3.3, we examine the distribution of payments to farmers ranked by income and in Section 3.4, ranked by the direct payments as a percentage of the agricultural income by farming type.

\subsection{Distribution of direct payments to farmers by payment amount}

In the field of economics, the Lorenz curve is used to show the income distribution of the population. The horizontal axis displays the cumulative percentage of the population size and the vertical axis displays the cumulative percentage of the income of that population. The points at the bottom-left and top-right of the Lorenz curve are fixed. These are points at which the cumulative population size and cumulative incomes are both $0 \%$ and $100 \%$ respectively. The line between these points indicates how even or uneven the income has been distributed. If the line is straight, the distribution is even, if not, then the distribution is unequal. We used the concept of the Lorenz curve to display the distribution of direct payments from the first pillar to farmers in the EU28 in 2015 (Figure 3.1). It turns out that the distribution of direct payments is rather uneven: roughly $80 \%$ of farmers in the EU28 received $20 \%$ of the total direct payments in 2015 . The remaining $20 \%$ of farmers - the group between $80 \%$ and $100 \%$ on the horizontal axis - received roughly $80 \%$ of the payments. Therefore, there is a large group of farmers in the EU28 who receive a significantly small amount of payments and a small group of farmers who receive a large amount of payments.

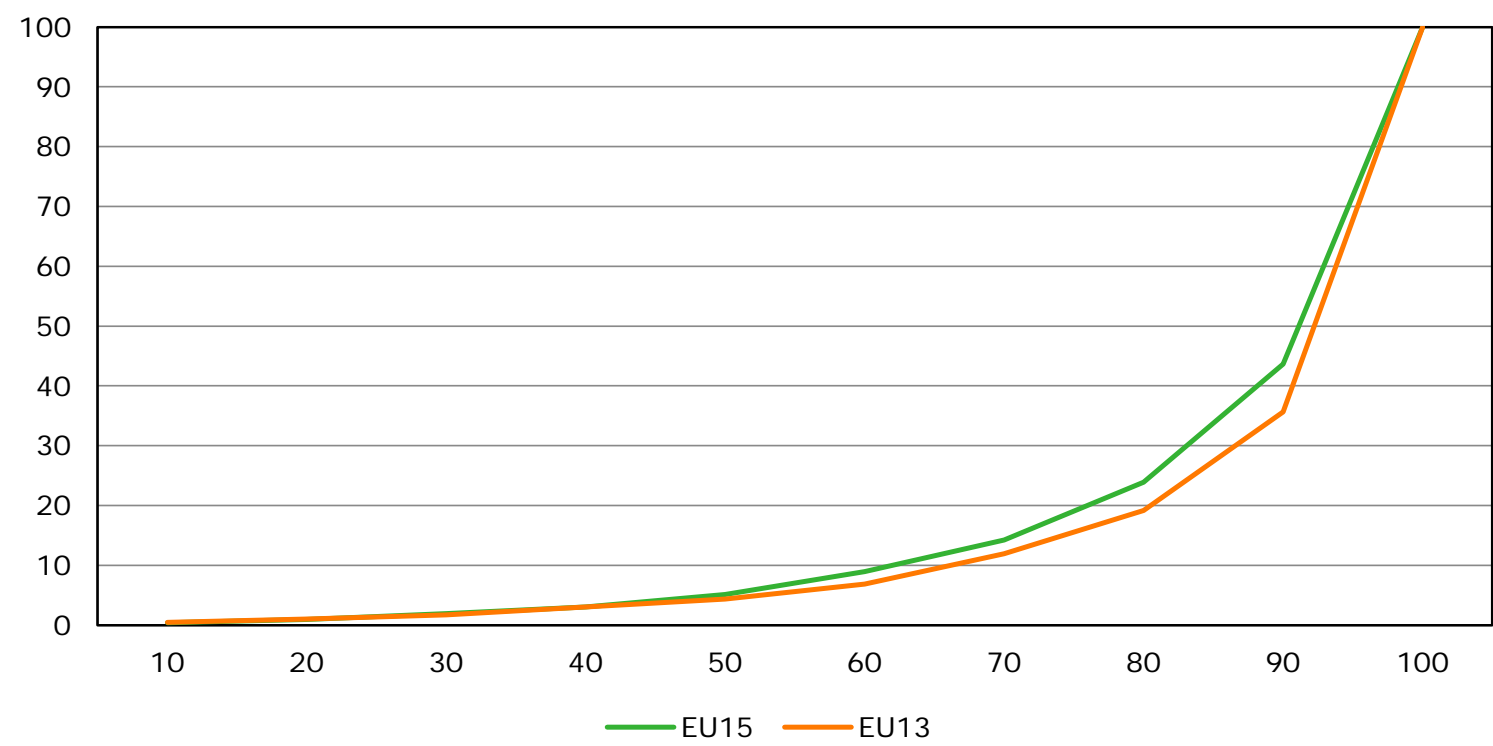

Figure 3.1 Distribution of direct payments from the first pillar to farmers in the EU28, 2015 (\%) a) a) With regard to the 2016 financial year Source: EC (2017b); adaptation by Wageningen Economic Research. 
Inequality of direct payment distribution to farmers varies between member countries

The size of the group of farmers who receive $20 \%$ of the direct payments varies substantially between member countries: it is relatively the smallest group in Luxembourg (54\%) and the largest in Slovakia (93\%) (Figure 3.2). Therefore, in Luxembourg, the distribution of payments is less uneven than the EU28 average, while in Slovakia, it is more uneven. I reland, the Netherlands, Belgium, France, Finland, and Austria also show a less uneven distribution of direct payments to farmers in comparison to other EU countries (Table B3.1).

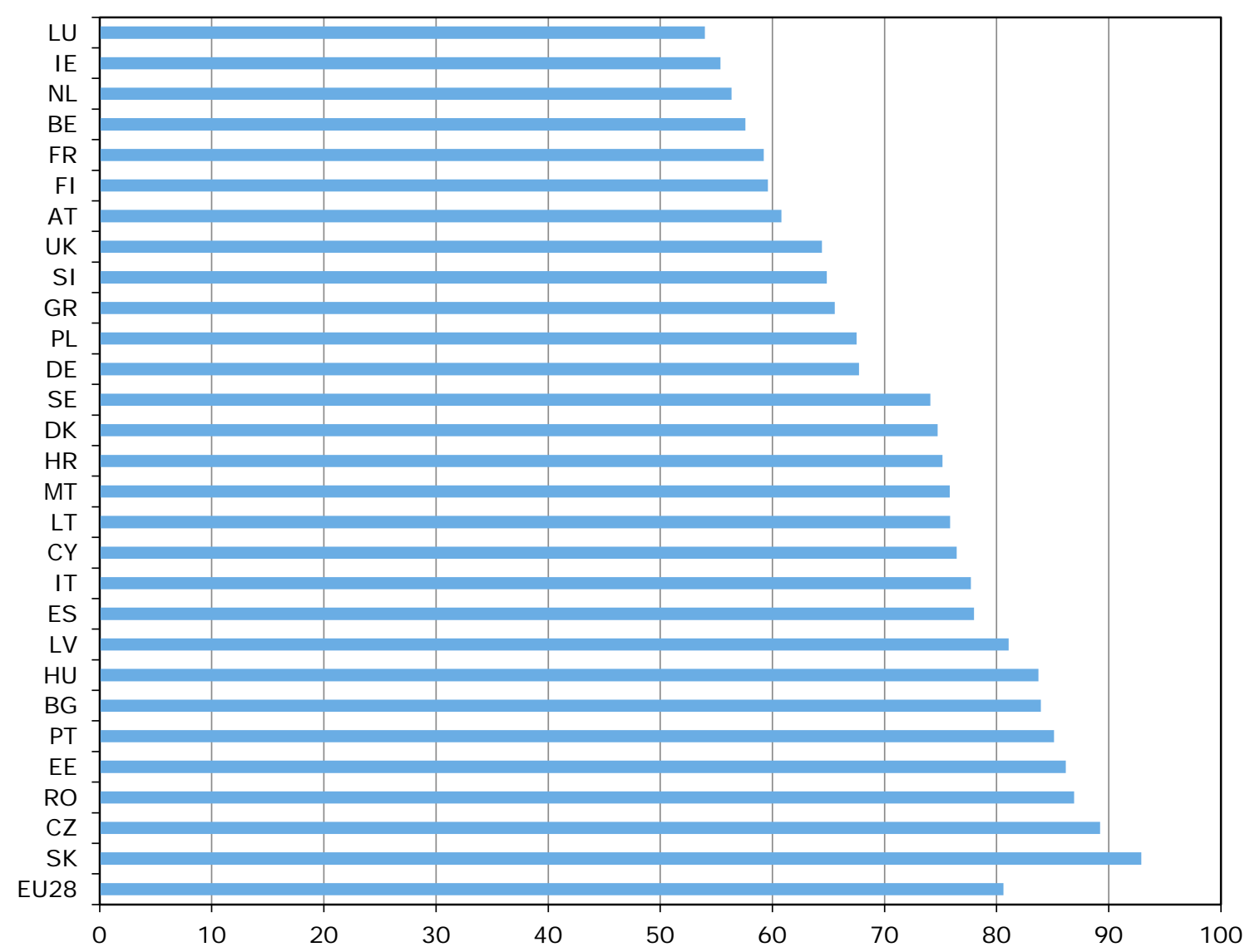

Figure 3.2 The percentage of farmers in each EU member country that receives $20 \%$ of CAP Pillar 1 payments, 2015 (\% of total number of farmers)

Source: EC (2017b); adaptation by Wageningen Economic Research.

Direct payment distribution to farms is related to the scale of the agricultural structure The distribution of payments to farmers shown in the Lorenz curve is related to the fact that not all farmers receive the same payment. The payment per farmer depends on the way of implementation at which the member country determines direct payments (historical reference, uniform hectare payment, coupled payments to production, granting optional payments as compensation for natural constraints, additional support for the first hectares, etc.). In spite of the differences in the implementation of the payments, member countries are required to abide by rules requiring the payments to converge at the average payment per hectare in their country. This results in a trend where farmers at farms with more hectares receive more payments than farmers at farms with fewer hectares. There are large differences in the size of the businesses between member states. For example, Malta, Bulgaria, Cyprus and Romania have very small-scale agricultural structures, where more than three quarters of the farms are smaller than 2 hectares (Table 3.1). In another group of member countries - Denmark, France, Luxembourg, the Czech Republic and the UK - roughly one fifth of the farms are larger than 100 hectares. Between these two extremes, there are two other 
groups of member countries: a group with a small-scale agricultural structure, where more than $70 \%$ of the farms are smaller than 20 hectares, and a group of member countries with a fairly even distribution of farms into size classes. The distribution of farms across the size classes impacts the distribution of payments to farmers. With a few exceptions, such as Greece, Poland and the Czech Republic, it turns out that the member countries with an even distribution of farms across the size classes and member countries with a relatively large number of farms over 100 hectares generally have a more equal distribution of payments to farmers than member countries with a (very) smallscale agricultural structure.

Table 3.1 Distribution of farms across size classes by hectare in EU member countries, 2013

\begin{tabular}{|c|c|c|c|c|c|c|c|c|c|c|}
\hline & \multirow[b]{2}{*}{$\begin{array}{l}\text { Total number } \\
\text { of farms } \\
(* 1,000)\end{array}$} & \multirow[b]{2}{*}{$\begin{array}{l}\text { Total number } \\
\text { of farms as } \% \\
\text { EU total }\end{array}$} & \multicolumn{8}{|c|}{ Distribution of farms by size class ( $\%$ of total) } \\
\hline & & & $<2$ ha & $\begin{array}{l}2 \text { to } \\
4.9 \text { ha }\end{array}$ & $\begin{array}{l}5 \text { to } \\
9.9 \text { ha }\end{array}$ & $\begin{array}{l}10 \text { to } \\
19.9 \text { ha }\end{array}$ & $\begin{array}{l}20 \text { to } \\
29.9 \text { ha }\end{array}$ & $\begin{array}{l}30 \text { to } \\
49.9 \text { ha }\end{array}$ & $\begin{array}{l}50 \text { to } \\
99.9 \text { ha }\end{array}$ & $>100$ ha \\
\hline \multicolumn{11}{|c|}{ Member states with a very small-scale agricultural structure (more than three quarters of the farms $<2$ ha) } \\
\hline Malta & 9.4 & 0.1 & 85 & 12 & 3 & 0 & 0 & 0 & 0 & 0 \\
\hline Bulgaria & 254.4 & 2 & 76 & 11 & 4 & 3 & 1 & 1 & 1 & 2 \\
\hline Hungary & 491.3 & 5 & 76 & 9 & 5 & 4 & 2 & 2 & 1 & 2 \\
\hline Cyprus & 35.4 & 0.3 & 75 & 15 & 5 & 3 & 1 & 1 & 1 & 0 \\
\hline Romania & $3,629.7$ & 33 & 73 & 19 & 5 & 1 & 0 & 0 & 0 & 0 \\
\hline \multicolumn{11}{|c|}{ Member states with a small-scale agricultural structure (more than $70 \%$ of the farms $<20$ ha) } \\
\hline Greece & 709.5 & 7 & 51 & 25 & 12 & 6 & 2 & 2 & 1 & 0 \\
\hline Portugal & 264.4 & 2 & 46 & 26 & 12 & 7 & 3 & 2 & 2 & 2 \\
\hline Croatia & 157.4 & 1 & 39 & 31 & 16 & 8 & 2 & 2 & 2 & 1 \\
\hline Slovakia & 23.56 & 0.2 & 32 & 27 & 12 & 9 & 3 & 3 & 3 & 10 \\
\hline Spain & 965 & 9 & 28 & 24 & 15 & 11 & 5 & 6 & 5 & 5 \\
\hline Italy & $1,010.3$ & 9 & 28 & 31 & 17 & 11 & 4 & 4 & 3 & 1 \\
\hline Slovenia & 72.4 & 1 & 26 & 34 & 24 & 11 & 3 & 1 & 1 & 0 \\
\hline Poland & $1,429.01$ & 13 & 23 & 31 & 22 & 15 & 4 & 3 & 1 & 1 \\
\hline Latvia & 81.8 & 1 & 23 & 20 & 20 & 19 & 7 & 5 & 3 & 4 \\
\hline Lithuania & 171.8 & 2 & 14 & 39 & 22 & 12 & 4 & 3 & 3 & 3 \\
\hline Austria & 140.4 & 1 & 11 & 20 & 17 & 22 & 12 & 10 & 6 & 2 \\
\hline \multicolumn{11}{|c|}{ Member states with an even distribution of farms across size classes } \\
\hline Ireland & 139.6 & 1 & 2 & 5 & 11 & 24 & 18 & 22 & 15 & 3 \\
\hline The Netherlands & 67.5 & 1 & 13 & 15 & 14 & 15 & 10 & 16 & 14 & 4 \\
\hline Belgium & 37.8 & 0.3 & 5 & 9 & 13 & 18 & 13 & 18 & 17 & 6 \\
\hline Finland & 54.4 & 1 & 2 & 3 & 11 & 20 & 15 & 20 & 19 & 8 \\
\hline Estonia & 19.2 & 0 & 11 & 22 & 21 & 17 & 7 & 6 & 6 & 9 \\
\hline Sweden & 67.2 & 1 & 2 & 10 & 23 & 20 & 10 & 11 & 12 & 12 \\
\hline Germany & 285 & 3 & 5 & 3 & 16 & 21 & 10 & 15 & 18 & 12 \\
\hline \multicolumn{11}{|c|}{ Member states with a relatively high number of large farms ( $>100$ ha) } \\
\hline Czech Republic & 26.3 & 0.2 & 11 & 7 & 19 & 18 & 9 & 9 & 9 & 18 \\
\hline Denmark & 38.3 & 0.4 & 3 & 2 & 20 & 18 & 10 & 11 & 14 & 21 \\
\hline France & 472.2 & 4 & 13 & 12 & 9 & 9 & 7 & 10 & 20 & 21 \\
\hline Luxembourg & 2.1 & 0.0 & 10 & 7 & 9 & 8 & 6 & 10 & 29 & 22 \\
\hline United Kingdom & 183 & 2 & 2 & 5 & 15 & 16 & 10 & 13 & 18 & 22 \\
\hline EU28 & $10,838.3$ & 100 & 45 & 21 & 12 & 8 & 3 & 4 & 4 & 3 \\
\hline
\end{tabular}

Source: Eurostat Farm Structure Survey (FSS); adaptation by Wageningen Economic Research.

Distribution will also be uneven with a uniform hectare payment

Given the agreements on the implementation of the 2014-2020 CAP, the direct payments per hectare from the first pillar must converge internally at the average hectare payment in a member country or be equal to it. In the latter case, there is a uniform hectare payment, which results in farmers receiving the same payment for every hectare. In order to check whether the distribution of direct payments changes when a uniform hectare payment is granted, we created a fictitious distribution. In 
this fictitious distribution, the farms are ranked by size in hectares: farmers in the lowest percentiles have few hectares per farm and farmers in the highest percentiles have many (Table 3.2). By multiplying the number of hectares in each percentile by the uniform hectare payment (Figure 3.3), we can calculate the payments received in each percentile. By definition, this fictitious distribution leads to an uneven distribution of payments: farmers in the lowest percentiles with few hectares per farm receive few payments and farmers in the highest percentages with many hectares per farm receive many more payments. From the fictitious distribution, we see that when a uniform hectare payment is granted, $20 \%$ of farmers in the EU28 receive $86 \%$ of the payments (Table B3.1). This fictitious distribution shows that a uniform hectare payment for the EU as a whole would lead to a more uneven distribution of payments to farmers than the actual 2015 distribution, where $20 \%$ of farmers received $81 \%$ of the payments. An equal distribution of payments to farmers can only occur under a uniform hectare payment if every farm in the EU28 had the same number of hectares. The current distribution of farms in the size classes by hectare deviates strongly from that situation.

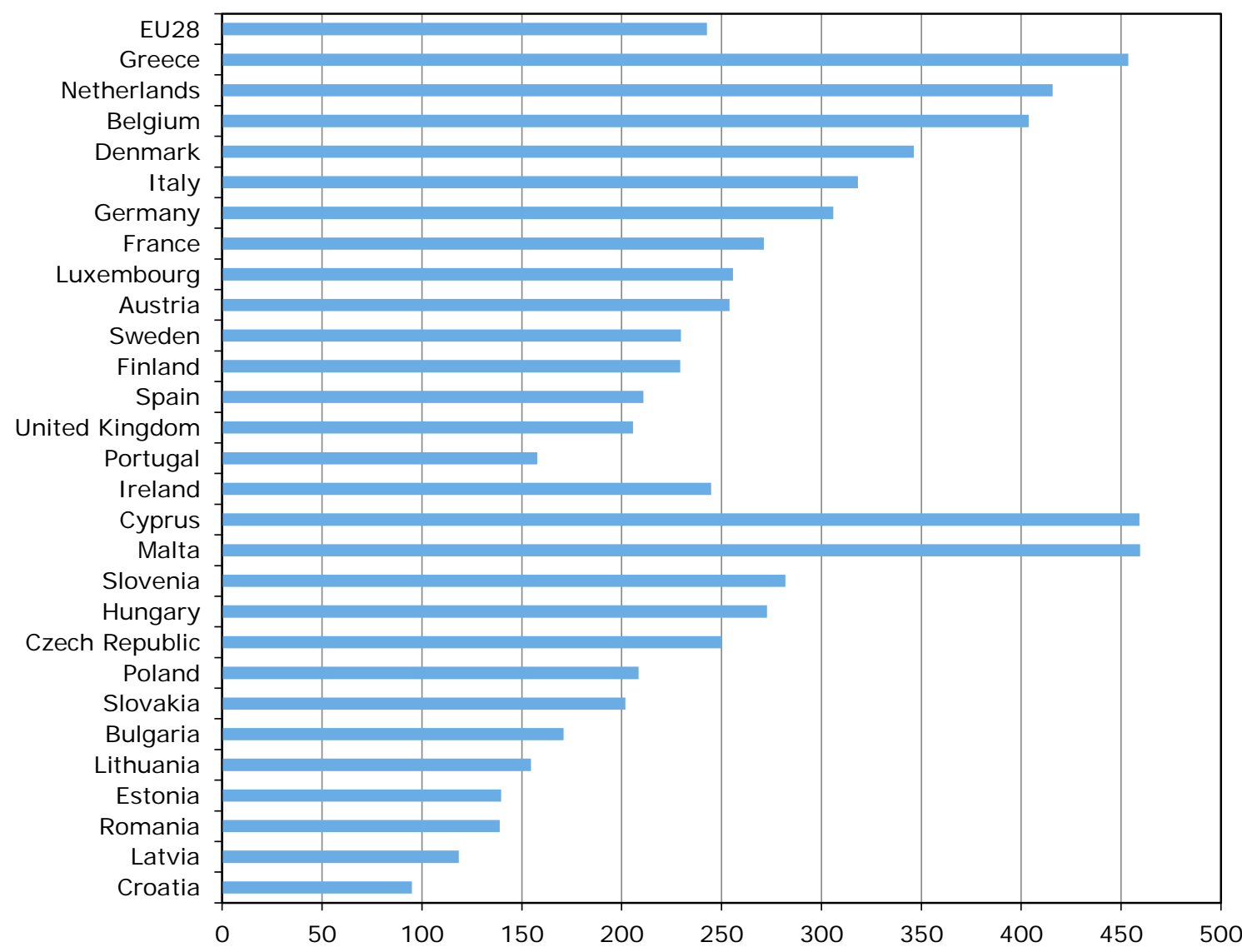

Figure 3.3 Average payment per hectare in the EU member countries, 2015 Source: EC (2013) and Eurostat Farm Structure Survey (FSS); adaptation by Wageningen Economic Research.

Fictitious distribution of payments to farmers in the member countries based on a uniform hectare payment

In the same way that was done for the EU28, we also created a fictitious distribution of uniform hectare payments to farms for each member country (Appendix B.1). If we compare the distribution based on uniform hectare payments with the distribution of the payments granted in 2015 (EC, 2017b), it turns out that several member countries (Denmark, Finland, I reland, I taly, Latvia, Malta, Poland, Romania, Slovenia, Slovakia, Czech Republic and Sweden) see decreases in the inequality of distribution, while other countries (Bulgaria, Cyprus, France, Greece, Hungary, Croatia, Luxembourg, the Netherlands, Portugal, Spain and the UK) see the distribution become more unequal (Table B3.1). There is also a group of member countries in which the distribution would remain unchanged 
(Belgium, Germany, Estonia, Lithuania and Austria). The reason why some member countries have lower equality in distribution and others more equality has not been shown to be related to the distribution of farms across size classes by hectare (Table 3.1). Apparently, country-specific factors, such as historical references for determining the payments, play a role in the direction of the shift in distribution.

Table 3.2 Fictitious distribution of a uniform hectare payment to farmers in the EU28, 2015 a)

\begin{tabular}{|c|c|c|c|c|c|c|c|}
\hline $\begin{array}{l}\text { Decile } \\
\text { no. }\end{array}$ & $\begin{array}{l}\text { Number of } \\
\text { farmers in } \\
\text { decile } \\
\text { (million) }\end{array}$ & $\begin{array}{l}\text { Average } \\
\text { farm size } \\
\text { (ha) }\end{array}$ & $\begin{array}{l}\text { Fictitiously } \\
\text { received } \\
\text { payments based } \\
\text { on a uniform } \\
\text { hectare } \\
\text { payment in } \\
\text { decile } \\
\text { (€ million) } \\
\text { (?) }\end{array}$ & $\begin{array}{l}\text { Decile } \\
\text { percentage } \\
\text { in total } \\
\text { fictitious } \\
\text { payments } \\
(\%)\end{array}$ & $\begin{array}{l}\text { Cumulative } \\
\text { number of } \\
\text { farmers } \\
\text { (million) }\end{array}$ & $\begin{array}{l}\text { Cumulative } \\
\text { number of } \\
\text { hectares } \\
\text { (million) }\end{array}$ & $\begin{array}{l}\text { Cumulative } \\
\text { receipt of } \\
\text { fictitious } \\
\text { payments } \\
\text { ( } € \text { million) }\end{array}$ \\
\hline & (1) & (2) & (3) & (4) & (5) & (6) & (7) \\
\hline 1 & 1.1 & 0.6 & 169 & 0.4 & 1.1 & 0.7 & 169 \\
\hline 2 & 1.1 & 0.8 & 200 & 0.5 & 2.2 & 1.5 & 369 \\
\hline 3 & 1.1 & 0.8 & 200 & 0.5 & 3.3 & 2.3 & 0 \\
\hline 6 & 1.1 & 3.2 & 835 & 2 & 6.5 & 8.7 & 2,122 \\
\hline 7 & 1.1 & 4.6 & 1,209 & 3 & 7.6 & 13.7 & 3,331 \\
\hline 8 & 1.1 & 8.4 & 2,199 & 5 & 8.7 & 22.8 & 5,530 \\
\hline 9 & 1.1 & 18.3 & 4,808 & 11 & 9.8 & 42.5 & 10,338 \\
\hline 10 & 1.1 & 121.9 & 32,094 & 76 & 10.8 & 174.6 & 42,431 \\
\hline
\end{tabular}

a) Column (3): calculated as the number of farmers in decile* number of hectares per farmer* uniform hectare payment of $€ 243$; Column (4): calculated as column (3) divided by the total number of payments in the EU28 (€4,2431; last number in column (7)); Column (6): calculated as column (1)* column (2); the total of the preceding deciles was then added together. Source: EC (2013) and Eurostat Farm Structure Survey (FSS); adaptation by Wageningen Economic Research.

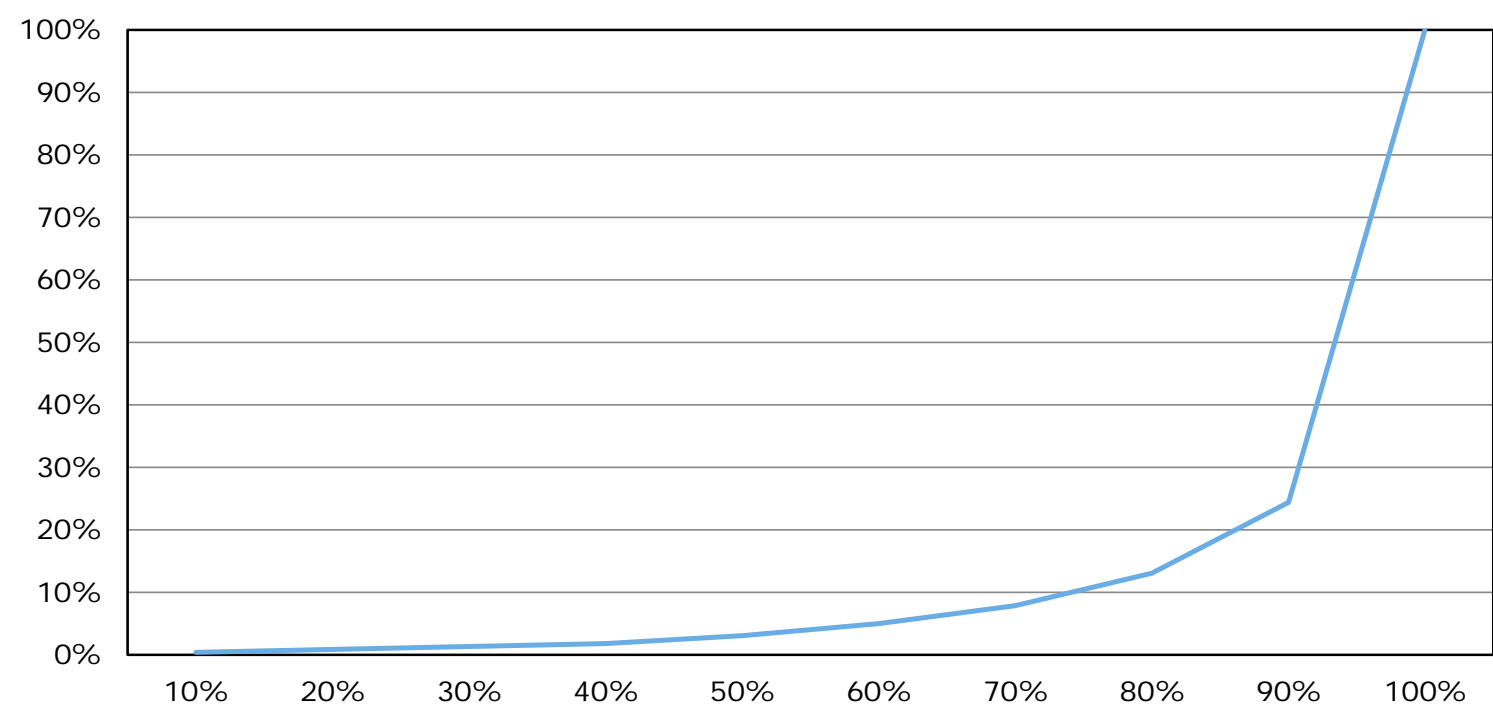

Figure 3.4 Fictitious distribution of payments to farms in EU member countries based on a uniform hectare payment, 2015

Source: EC (2013) and Eurostat Farm Structure Survey (FSS); adaptation by Wageningen Economic Research. 
Farms with a small or large amount of direct payments

In $2015,27 \%$ of the farmers in the EU28 that were eligible for direct payments from the first pillar of the CAP received payments of less than $€ 500$ (Table 3.3). This percentage varied from less than half a percent in Denmark and the Netherlands to $72 \%$ in Malta. It turns out that there are few farmers who were entitled to direct payments, but did not receive them: in the EU28, it was about 2,307 farmers, primarily from Italy, Croatia, and Lithuania (Table B3.2). Apparently, the small farmers scheme provides a fairly simple way for farmers with small farms to apply for direct payments. Less than 16,000 farmers in the EU28 received more than $€ 150,000$ in payments in 2015 . Most of them are farms in Germany (around 3,300); Italy, Spain, Czech Republic and the UK $(1,500-1,600)$; and Bulgaria, Denmark, France, Hungary, Poland, Romania and Slovakia (600-1,100) (Figure 3.5). As a percentage of the total number of beneficiaries, this group of big beneficiaries is very small: in the EU28, this concerns $0.2 \%$ of the recipients. The percentage was only larger in Slovakia and the Czech Republic, at around $5 \%$. The percentage of the payments to this group of big recipients in the total payments was $11 \%$ in the EU28 in 2015 . This percentage varies substantially between member countries, from zero in Greece and Malta to $69 \%$ in Slovakia (Figure 3.6).

Three quarters of farmers in the EU28 received less than $€ 5,000$ of payments in 2015 Roughly three quarters of farmers in the EU28 received less than $€ 5,000$ of payments in 2015 (Table B3.3). Among those farmers, one quarter received less than $€ 500$, one quarter received between $€ 500$ and $€ 1,250$, and one quarter received between $€ 1,250$ and $€ 5,000$.

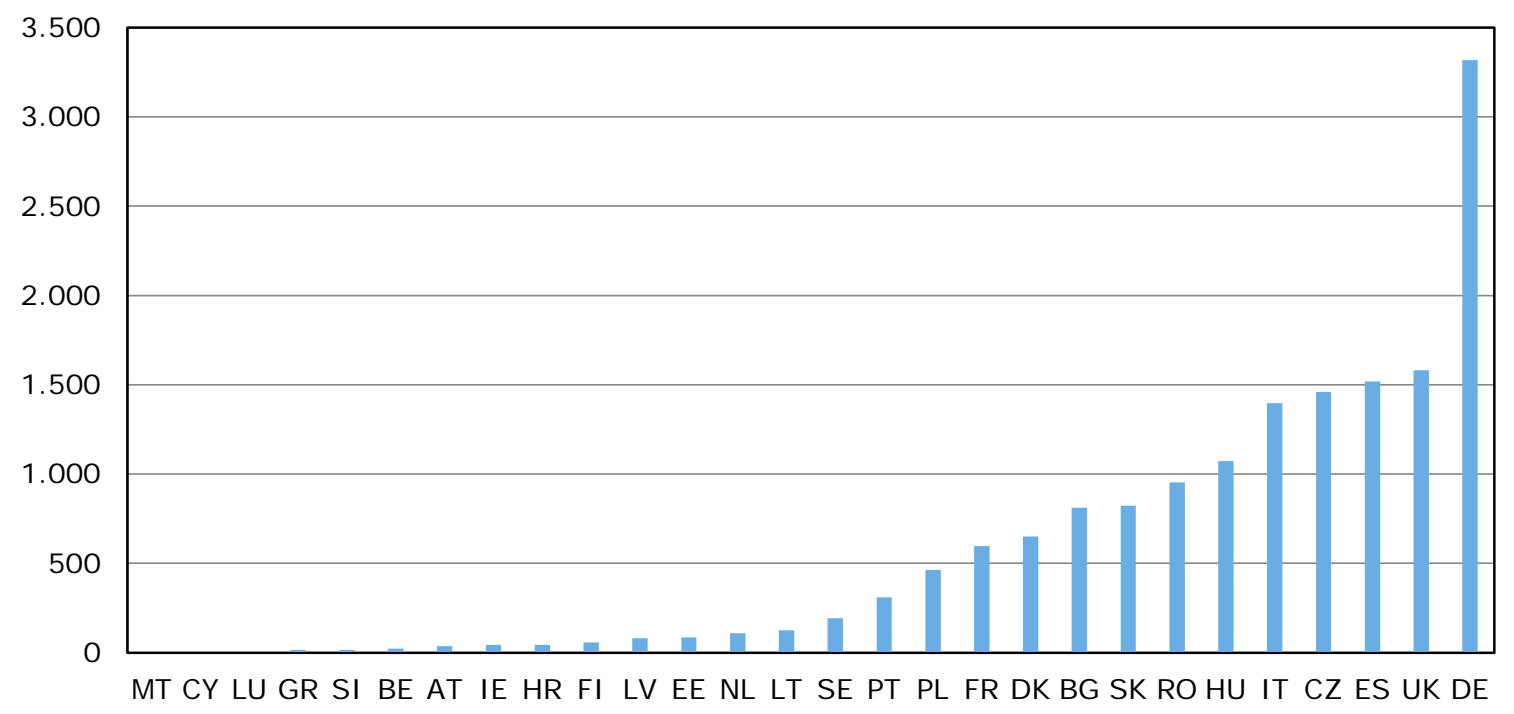

Figure 3.5 Number of farmers that received more than $€ 150,000$ of direct payments in the EU member countries, 2015

Source: EC (2017b); adaptation by Wageningen Economic Research. 
Table 3.3 Farmers who received few/many payments in the EU member countries, 2015 (\% total number of farmers)

\begin{tabular}{|c|c|c|c|}
\hline & Few payments & & Many payments \\
\hline & $\begin{array}{l}\% \text { farmers that received } \\
\text { no payments }\end{array}$ & $\begin{array}{l}\% \text { farmers that received } \\
€ 0-500 \text { in payments }\end{array}$ & $\begin{array}{l}\% \text { farmers that received more than } \\
€ 150,000 \text { in payments }\end{array}$ \\
\hline SK & 0.0 & 22.8 & 4.5 \\
\hline DK & 0.2 & 0.3 & 1.6 \\
\hline UK & 0.0 & 0.8 & 1.1 \\
\hline DE & 0.0 & 4.4 & 1.0 \\
\hline $\mathrm{HU}$ & 0.1 & 4.8 & 0.6 \\
\hline EE & 0.0 & 26.5 & 0.5 \\
\hline PT & 0.0 & 52.4 & 0.2 \\
\hline FR & 0.0 & 4.9 & 0.2 \\
\hline IT & 0.1 & 23.3 & 0.2 \\
\hline LV & 0.0 & 18.0 & 0.1 \\
\hline $\mathrm{FI}$ & 0.0 & 1.7 & 0.1 \\
\hline LU & 0.0 & 4.4 & 0.1 \\
\hline RO & 0.0 & 64.6 & 0.1 \\
\hline LT & 0.4 & 31.7 & 0.1 \\
\hline $\mathrm{BE}$ & 0.0 & 1.9 & 0.1 \\
\hline $\mathrm{CY}$ & 0.1 & 55.9 & 0.0 \\
\hline GR & 0.0 & 20.2 & 0.0 \\
\hline MT & 0.0 & 72.0 & 0.0 \\
\hline EU28 & 0.0 & 26.7 & 0.2 \\
\hline
\end{tabular}

Source: EC (2017b); adaptation by Wageningen Economic Research.

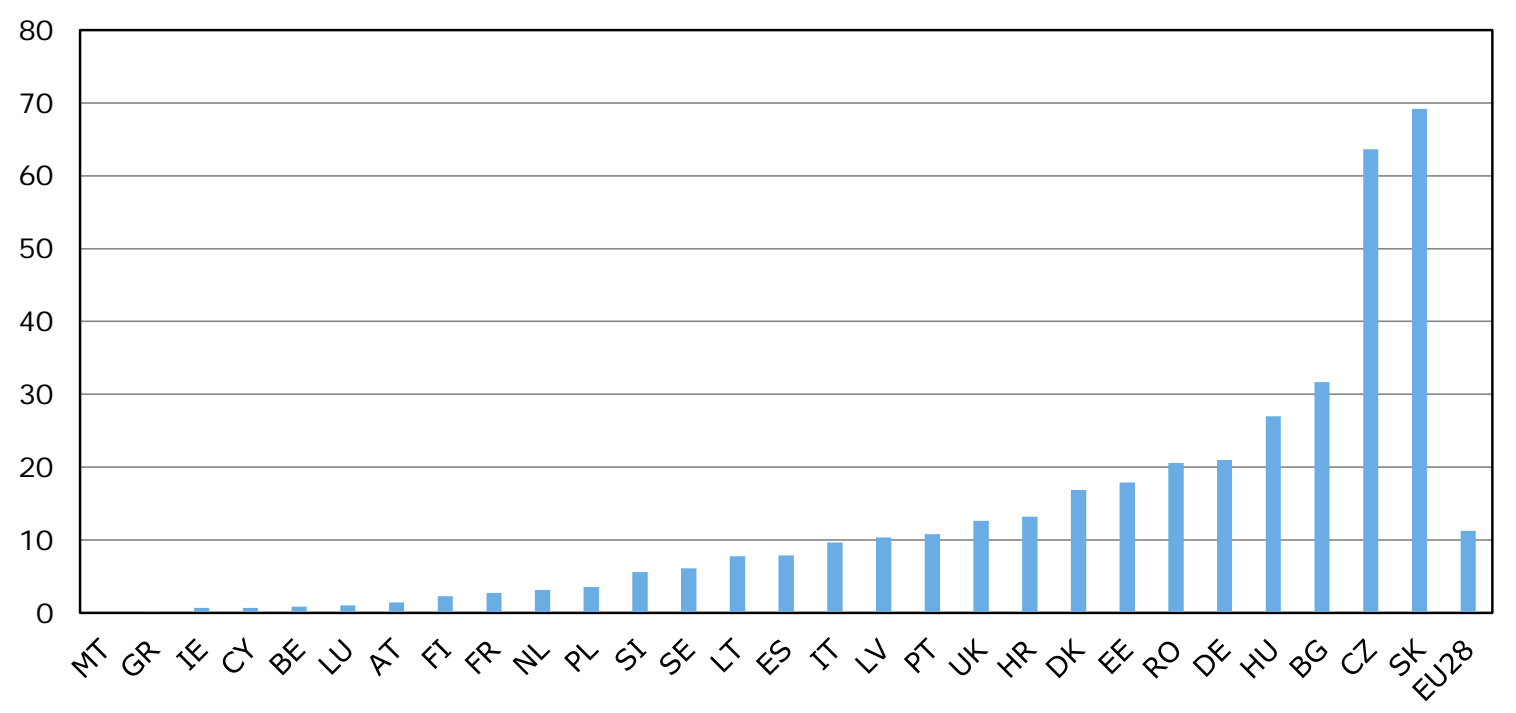

Figure 3.6 Percentage of farmers that received more than $€ 150,000$ in total payments in the EU member countries, 2015 (\% of the total number of payments)

Source: EC (2017b); adaptation by Wageningen Economic Research. 


\subsection{Distribution of direct payments to farmers by economic size class}

In the previous section, we discussed the distribution of payments to farms and farmers and we also paid attention to the size of the farms in hectares. However, the contribution of the direct payments to agricultural income was not discussed in that section. We will do that in this section using data from the Farm Accountancy Data Network (FADN). With this data, we can divide farms into so-called economic classes that reflect the standardised annual earning capacity of the farms in each class. The greater the earning capacity of a class, the higher the average agricultural income of the farms in that group. Since FADN only focused on commercial farms, some of the - primarily small - farms that were in the EC data on the distribution of direct payments to farmers were not included in FADN data. In order to estimate the contribution of the payments to the agricultural income of all farms, we have linked EC data with FADN data according to the assumptions described in Chapter 2. Through this link, it is possible to include roughly $96 \%$ of all beneficiaries as well as the total direct payments from the EC data in the calculations in this section.

Payment distribution ranked by farm income is somewhat less uneven

The distribution of payments to farmers ranked by income shows that the group of $80 \%$ of the farmers with the lowest incomes in the EU28 received $25 \%$ of the payments (Figure 3.7). This picture deviates somewhat from the $80 \%-20 \%$ distribution of farmers across the payment-based classes (Figure 3.1). On the one hand, this deviation is related to farms that have a low income, but receive many payments; on the other hand it is connected to farms that have a high income, but receive relatively few payments (Matthews, 2016). The first group includes farms such as extensive sheep farms, while the second group includes horticultural farms.

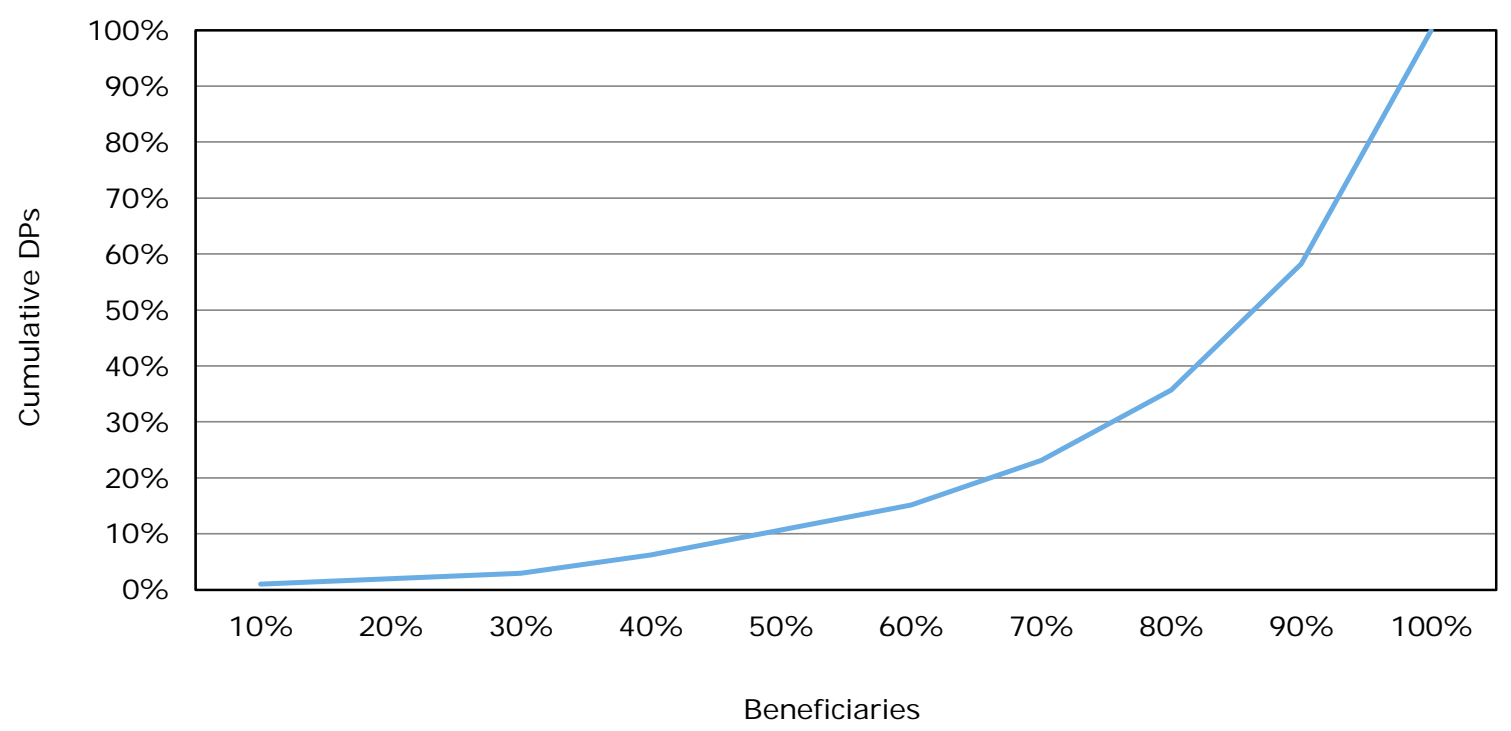

Figure 3.7 Distribution of payments to farmers ranked by income in the EU28, 2015 Source: FADN and EC (2017b); adaptation by Wageningen Economic Research.

Farmers in the highest income decile received roughly $50 \%$ of the payments The average agricultural incomes including payments in the EU28 vary widely in the income deciles: from less than $€ 1,000$ in the first decile to more than $€ 65,000$ in the last decile (Table 3.4). The payments as a percentage of income in the EU28 is substantial and varies from one third to one half. The $50 \%$ of farmers with the lowest incomes (deciles 1-5) received $4 \%$ of the total payments in 2015 , while the $10 \%$ of farmers in the highest decile received $53 \%$ of the total payments. Therefore, as agricultural income increases, farmers receive higher direct payments on average. This observation is nothing new and has regularly led to commentary in the literature on the inefficacy of the CAP as an income policy and that social policy would be a more appropriate instrument to support agricultural 
incomes (Matthews, 2016). An example of this would be a person-based payment related to the regional minimum income (Vogelzang et al., 2016). The agricultural income at many farms is also supplemented by incomes from non-agricultural activities, benefits, and pensions. Data on the total household income at farms is largely lacking and was not included in the FADN data (Strijker, 2017). If we take the supplementary incomes into account, the agricultural incomes can be viewed in a different light. In many instances, then there would be a reasonable income for a family farm. In the EU28, roughly a third of the total number of farms acquired income from non-agricultural activities (Terluin et al., 2017). This percentage shows significant differences between the member countries: in Sweden, it only involves $6 \%$ of farms, but in Bulgaria, Finland, and Slovenia $70-80 \%$ of farms accumulate non-agricultural income.

Table 3.4 Income and payments per farm in income deciles in the EU28, 2015

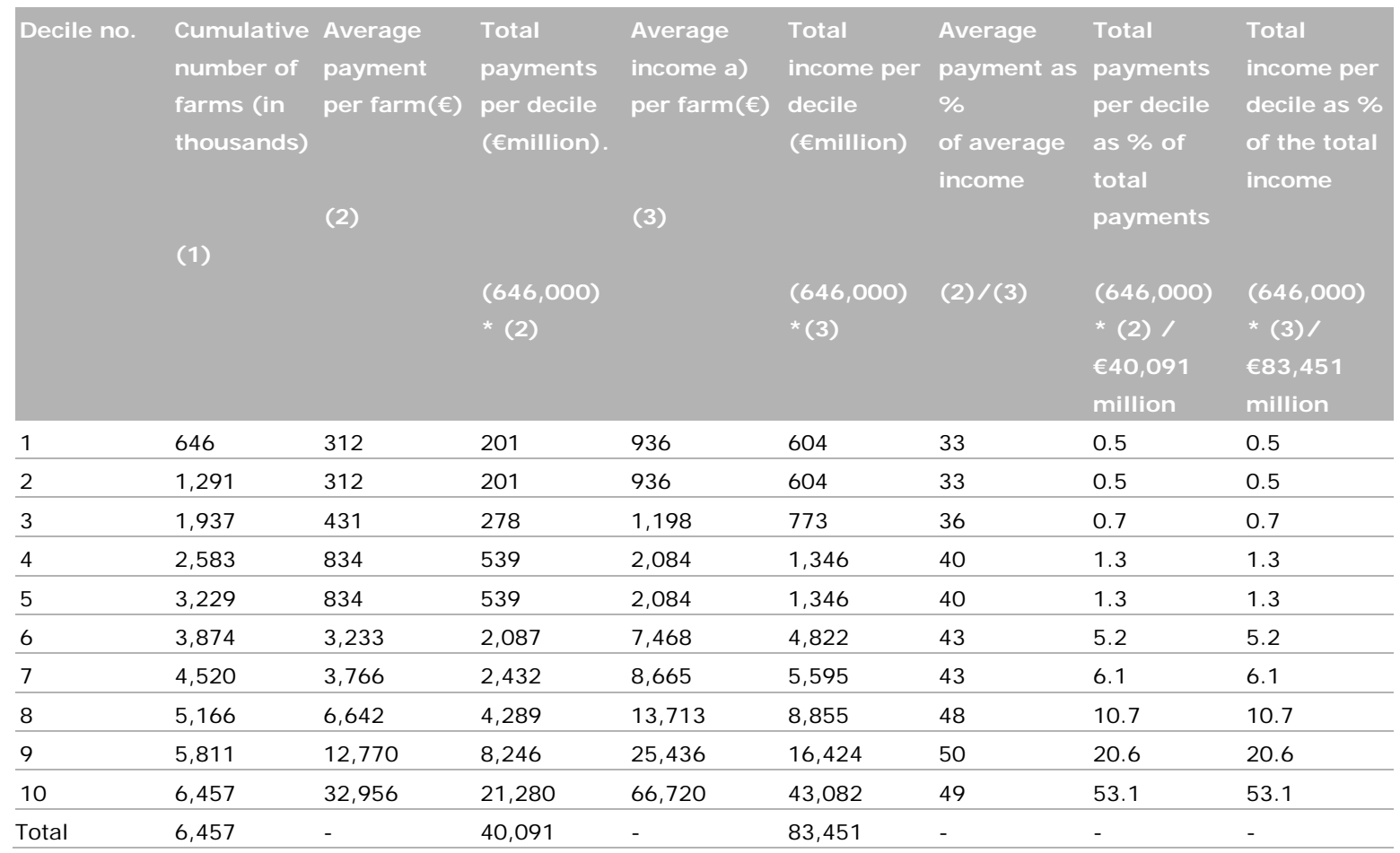

a) Family farm income (FADN variable SE420).

Source: FADN; adaptation by Wageningen Economic Research.

\subsection{Direct payments as a percentage of the agricultural income per farming type}

FADN subdivides farms into a number of farming types: specialised farms with cereals, oilseed and protein crops; specialised farms with other field crops; specialised milk farms; specialised sheep/goat farms; specialised cattle farms; and specialised granivores. This makes it possible to map out the differences in the payments received and the amount of agricultural income per farming type. Using FADN data, it is also possible for us to calculate the payments as a percentage of the income per farming type. Since agricultural incomes can fluctuate significantly from year to year, the payments as a percentage of agricultural income may differ annually as well (Van der Meulen et al., 2017). In this section's analysis, we address the agricultural income using the family farm income per family work unit.

On average, the payments as a percentage of the family farm income per family work unit was between roughly $50 \%-70 \%$ at farms with other field crops, dairy farms, and sheep/goat farms in the EU28 during the 2004-2015 period (Figure 3.8). The percentage at the cattle farms was over $100 \%$ : 
that means that these farms would be in the red without the payments. At farms with cereals, oilseed and protein crops, the payments as a percentage of income was around $100 \%$. The payments as a percentage of the incomes at intensive livestock farms is relatively low: this is due to the limited agricultural area at these farms and they do not have a tradition of receiving much CAP support.

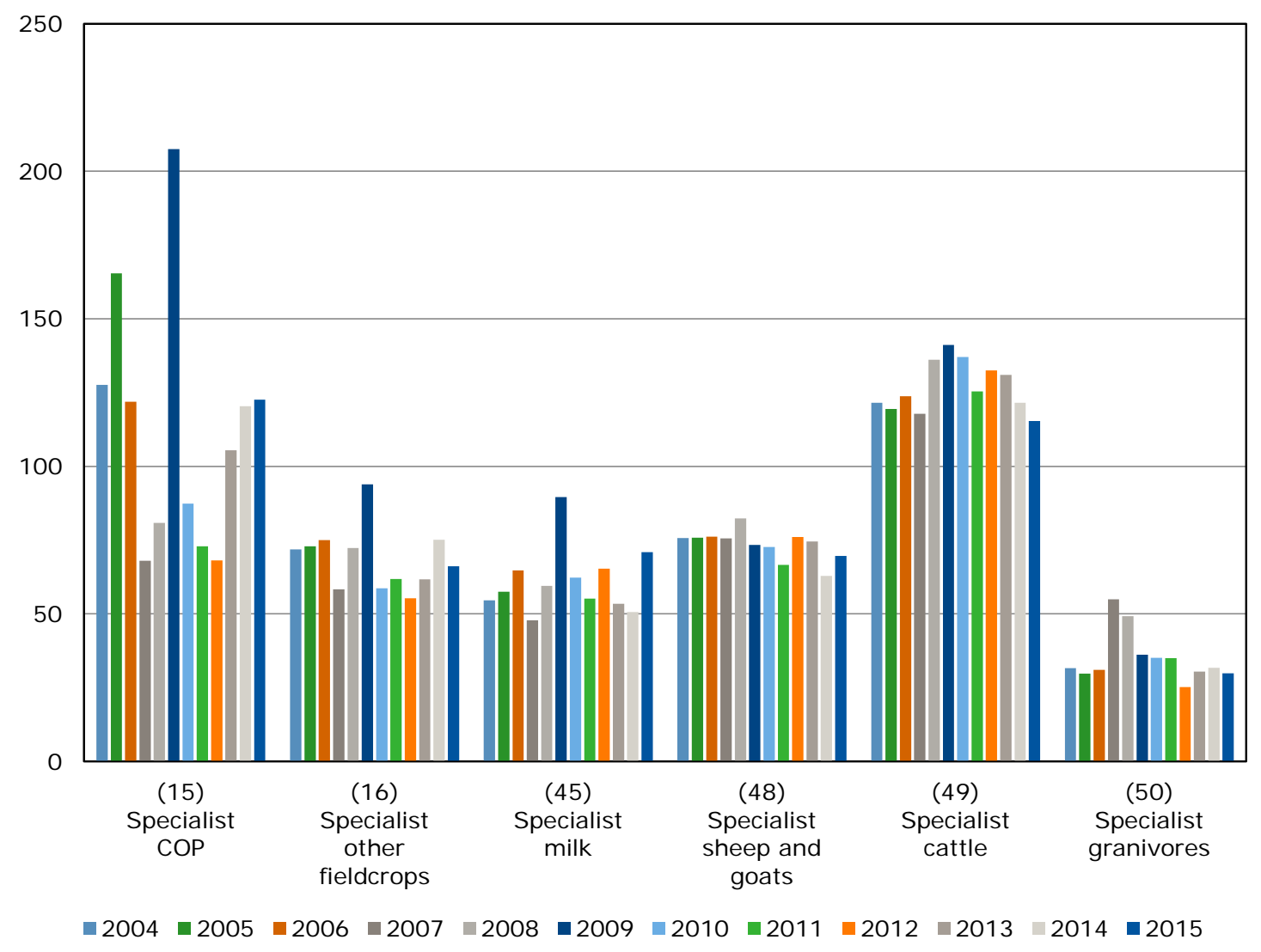

Figure 3.8 Payments from the first pillar of the CAP as a percentage of the family farm income per family work unit by farming type in the EU28, 2004-2015

Farming type (15) specialist COP are farms that specialise in cereals, oilseed and protein crops. Source: FADN; adaptation by Wageningen Economic Research.

Family farm incomes are often below GDP per capita

By comparing the income at farms with a yardstick for the average income in a region or member country, we can determine whether the family farm income per family work unit is relatively high or low. We used the gross domestic product (GDP) per capita as a reference income. Although this income is fairly low because it also contains the incomes of non-active persons such as children and retirees, this also has the significant advantage over other income references that EU GDP data has been harmonised and is available for all member countries. In most of the member countries, family farm income per family work unit is below the GDP per capita (Table B3.5). However, in Belgium, Bulgaria, Germany, France, Greece, Latvia, Lithuania, the Netherlands, Romania and the UK, one or two farming types exist for which the income per family working unit is above the GDP per capita. In contrast, in Hungary, Italy, Spain, Slovakia and the Czech Republic, family farm incomes are above the GDP per capita for most farming types. When interpreting these figures, it must be considered that on a significant number of farms, supplementary incomes are generated from non-agricultural activities, pensions and benefits (see also Section 3.3).

The payments from the first pillar per family work unit at the various farming types in the EU member countries had a maximum average of $€ 47,000$, with the exception of Slovakia and, to a lesser degree, the Czech Republic, where the average payments were significantly higher $(€ 65,000-178,000)$ (Table B3.6). All member countries, with the exception of Belgium, Italy, Malta, Portugal, Romania 
and Spain, have one or more farming types for which the direct payments make up more than $100 \%$ of the income (Figure B2.1-22; Table B3.7). Without payments, the family farm incomes per family work unit would be in the red at these farming types (Table B3.8). A negative agricultural income indicates that the costs associated with agricultural production are higher than its revenues. 


\section{Conclusions}

Within the context of the first pillar of the CAP, farmers receive direct payments. These are meant to generate reasonable incomes in the agricultural sector. In this study, it was examined how direct payments were distributed to farmers in 2015 and what differences were present between the member countries.

In $2015,81 \%$ of the farmers in the EU28 received $20 \%$ of the direct payments The distribution of direct payments from the first pillar of the CAP were shown to be uneven: in 2015, $81 \%$ of the farmers in the EU28 received $20 \%$ of the direct payments. Therefore, there is a large group of farmers in the EU28 who receive a relatively small amount of direct payments and a small group of farmers who receive a relatively large amount of payments. The size of the group of farmers who receive $20 \%$ of the direct payments varies substantially between member countries: it is relatively the smallest in Luxembourg (54\%) and the largest in Slovakia (93\%) (Figure 3.2). Therefore, in Luxembourg, the distribution of payments is less uneven than the EU28 average, while in Slovakia, it is more uneven.

Uneven distribution of payments is partially related to a difference in farm size The direct payments are partly based on the number of hectares per farm and partly based on country-specific elements such as historical references and coupled payments. As long as the CAP offers different options to member countries for the way in which payments are granted, it can be expected that there will be differences between member countries in the distribution of the payments to farmers due to the use of specific options. However, an unequal distribution of payments to farmers would also result if member countries are only permitted to grant them as a uniform hectare payment. A fictitious distribution of payments based on a uniform hectare payment to farmers shows that this is an even more uneven distribution than was the actual distribution in 2015: in that case, roughly $86 \%$ of farmers in the EU28 would receive $20 \%$ of the payments. In that fictitious distribution, small farmers receive a relatively small amount of payments and large farmers receive a relatively large amount. The group of small farmers is much larger than the group of large farmers: in $2013,45 \%$ of the farms in the EU28 had less than 2 hectares, 41\% had between 2 and 20 hectares, 11\% had between 20 and 100 hectares, and 3\% had more than 100 hectares. The distribution of farms across size classes by hectares in individual member countries fluctuates substantially from the EU average. An equal distribution of payments to farmers can only occur under a uniform hectare payment if every farm in the EU28 has the same number of hectares. The current distribution of farms over size classes deviates strongly from that situation.

Structural characteristics of businesses that receive many or few payments

The amount of the payments received varies widely: in 2015, over a quarter of farmers in the EU28 received a payment of less than $€ 500$ and $0.2 \%$ received a payment of more than $€ 150,000$. Only a limited number of farmers (about 2,300 farmers in the EU28) who were eligible for payments in 2015 did not receive them. Since the EC data (2017b) on the distribution of payments to farmers is not paired with data about other farm characteristics, we can only estimate the structural characteristics of farms with a small or a large amount of payments by linking EC data to other databases. This led to the following observations:

- farms with a small amount of payments had fewer hectares on average than those with a large amount of payments;

- as farm incomes get higher, the amount of the payments received often increases as well;

- specialised cattle farms and farms with cereals, oilseed and protein crops received the highest average payments in the EU28 and intensive livestock farms received the lowest. Farms with other field crops, dairy farms, and sheep/goat farms occupied the middle position.

It must be considered that these three observations are based on EU averages and that the situation on individual farms may vary. 
The direct payments as a percentage of agricultural income varies widely

The $50 \%$ of farmers with the lowest incomes in the EU28 received $4 \%$ of the total payments in 2015 , while the $10 \%$ of farmers with the highest incomes received $53 \%$ of the total payments. The payments as a percentage of family farm income per family work unit in the EU28 is significant and varies from a third for the lower income classes to half in the higher income classes. Therefore, as farm income increases, farmers receive higher direct payments on average. The payments as a percentage of farm income for the different farming types varies substantially from the EU average: in 2015 , the payments as a percentage of family farm income per family work unit at cattle farms and farms specialising in cereals, oilseed and protein crops were over $100 \%$, the percentage for farms producing other field crops, dairy farms, and sheep/goat farms was around $70 \%$, and the percentage for intensive livestock farms stood at roughly $30 \%$. Since agricultural incomes can fluctuate significantly from year to year, the payments as a percentage of agricultural income differ annually as well. 


\section{References and websites}

EC (European Commission) (2013). Regulation (EU) No 1307/2013 of the European Parliament and of the Council of 17 December 2013 establishing rules for direct payments to farmers under support schemes within the framework of the common agricultural policy and repealing Council Regulation (EC) No 637/2008 and Council Regulation (EC) No 73/2009; Brussels, Official Journal L 347/608

EC (2015). Report on the distribution of direct payments to agricultural producers (financial year 2014); Brussels

EC (2017a). The Future of Food and Farming; Brussels, Communication from the Commission of the European Parliament, the Council, the European Economic and Social Committee, and the Committee of the Regions, COM (2017) 713 def

EC (2017b). Report on the distribution of direct payments to agricultural producers (financial year 2016); Brussels

Matthews, A. (2016). Focus on the distribution of direct payments; Via website: http: //capreform. eu/focus-on-the-distribution-of-direct-payments/

Meulen, H.A.B van, A.B. Smit and J.H. Jager (2017). Effecten van het GLB op inkomens, kosten en administratieve lasten (CAP impacts on income, costs and adminsitrative burden); Wageningen, Wageningen Economic Research, Report 2017-080

Strijker, D. (2017). Smal en gefocust; Een essay over het toekomstige Europese Landbouwbeleid (Narrow and focussed; An essay on the future CAP); Groningen, RUG, URSI Research Report 359

Terluin, I., T. Kuhmonen, and P. Berkhout (2017). Flexibility given to Member States in CAP implementation: state of play and perspectives; Brussels, European Parliament, Policy Department for Structural and Cohesion Policies, Research for AGRI Committee

Vogelzang, T., P. Berkhout, A. van Doorn, R. Jongeneel, K. Poppe, B. Smit, and I. Terluin (2016). Het GLB na 2020; Schets voor een herontwerp (CAP beyond 2020; suggestions for adjustment); The Hague, LEI report 2016-009 


\section{Appendix 1 Fictitious distribution of direct payments to farms in EU member countries based on a uniform hectare payment}

Distribution of direct payments based on a uniform hectare payment over farms in Belgium

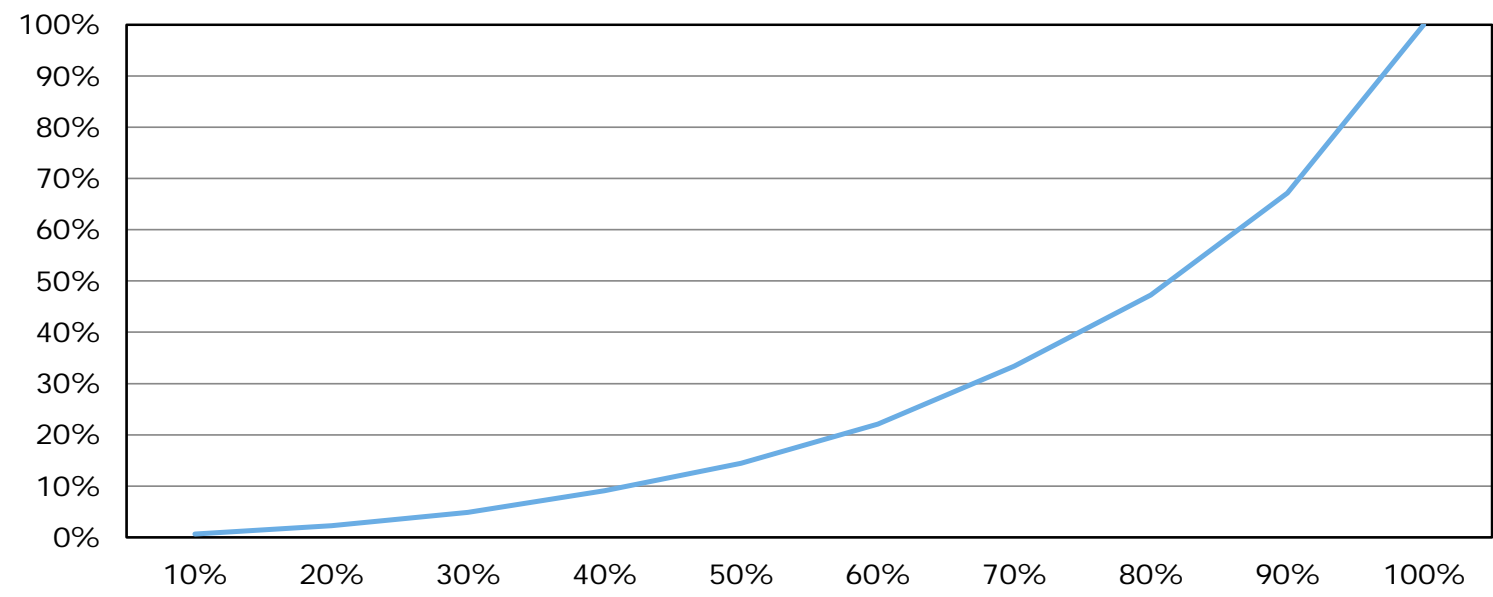

Figure B1.1 Fictitious distribution of payments to farms in Belgium based on a uniform hectare payment, 2015

Source: EC (2013) and the Eurostat Farm Structure Survey (FSS); adaptation by Wageningen Economic Research.

Distribution of direct payments based on a uniform hectare payment over farms in Bulgaria

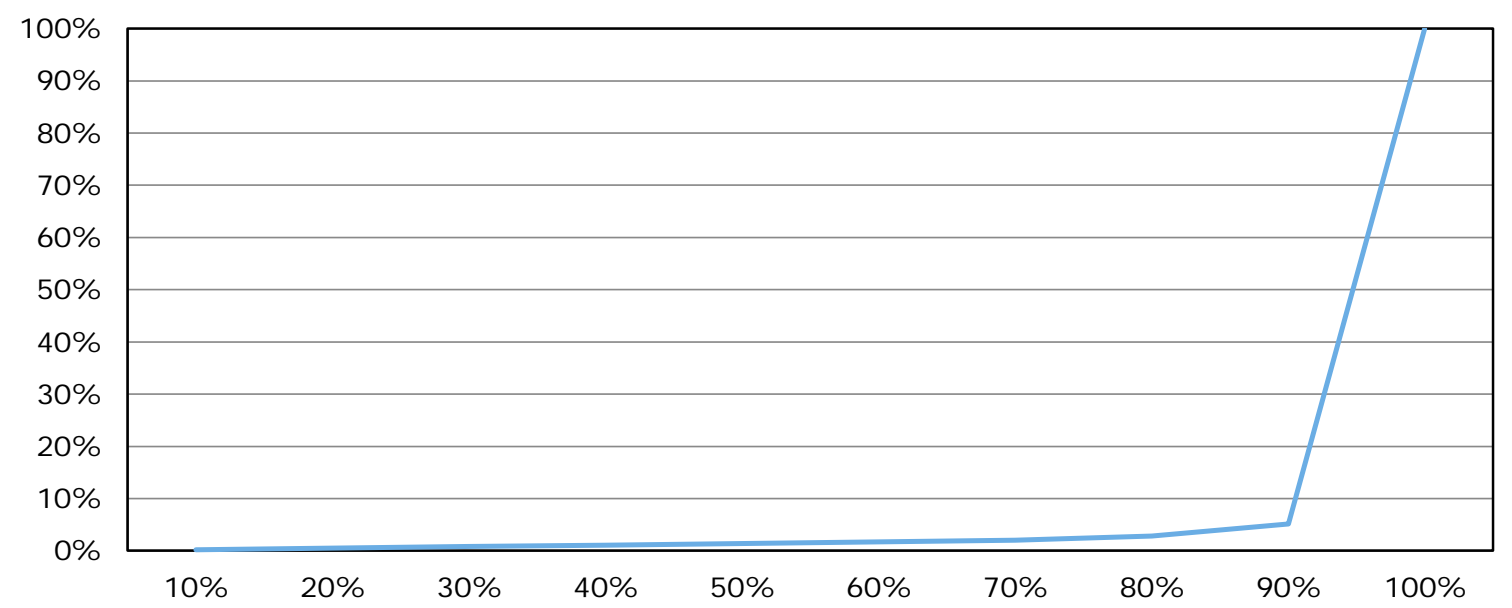

Figure B1.2 Fictitious distribution of payments to farms in Bulgaria based on a uniform hectare payment, 2015

Source: EC (2013) and the Eurostat Farm Structure Survey (FSS); adaptation by Wageningen Economic Research. 


\section{Distribution of direct payments based on a uniform hectare payment}

over farms in Czech Republic

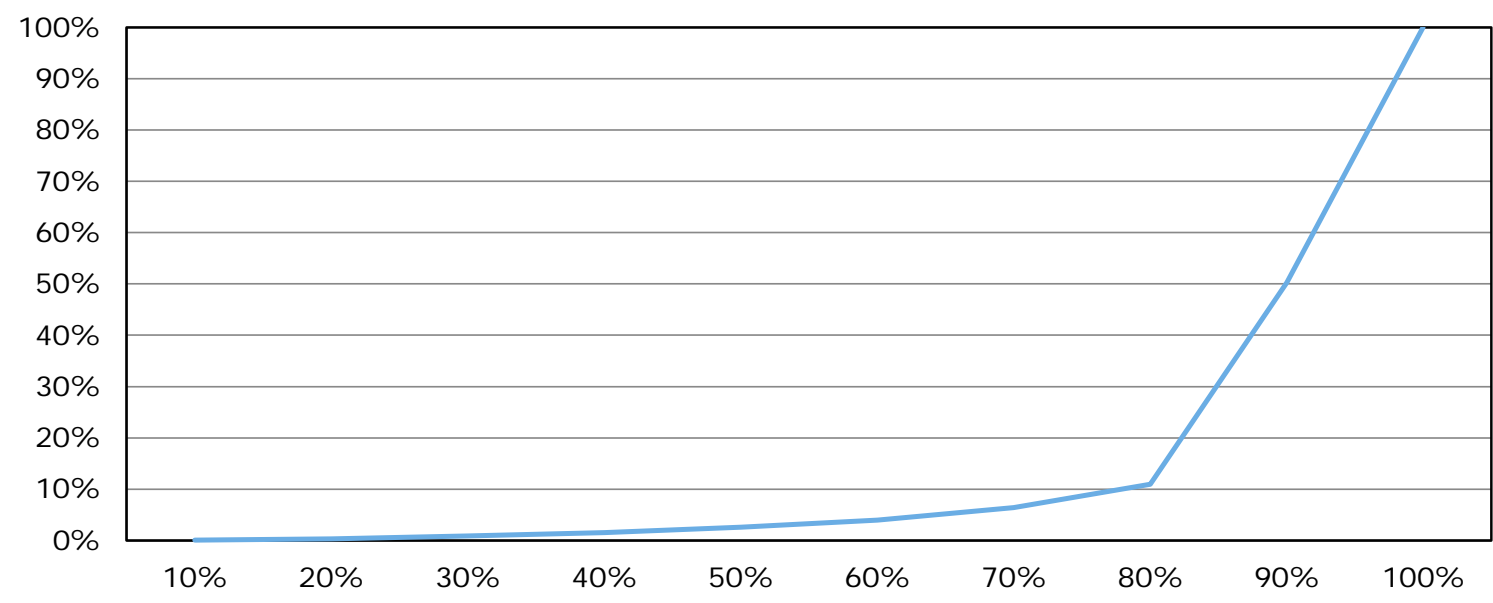

Figure B1.3 Fictitious distribution of payments to farms in the Czech Republic based on a uniform hectare payment, 2015

Source: EC (2013) and the Eurostat Farm Structure Survey (FSS); adaptation by Wageningen Economic Research.

Distribution of direct payments based on a uniform hectare payment over farms in Denmark

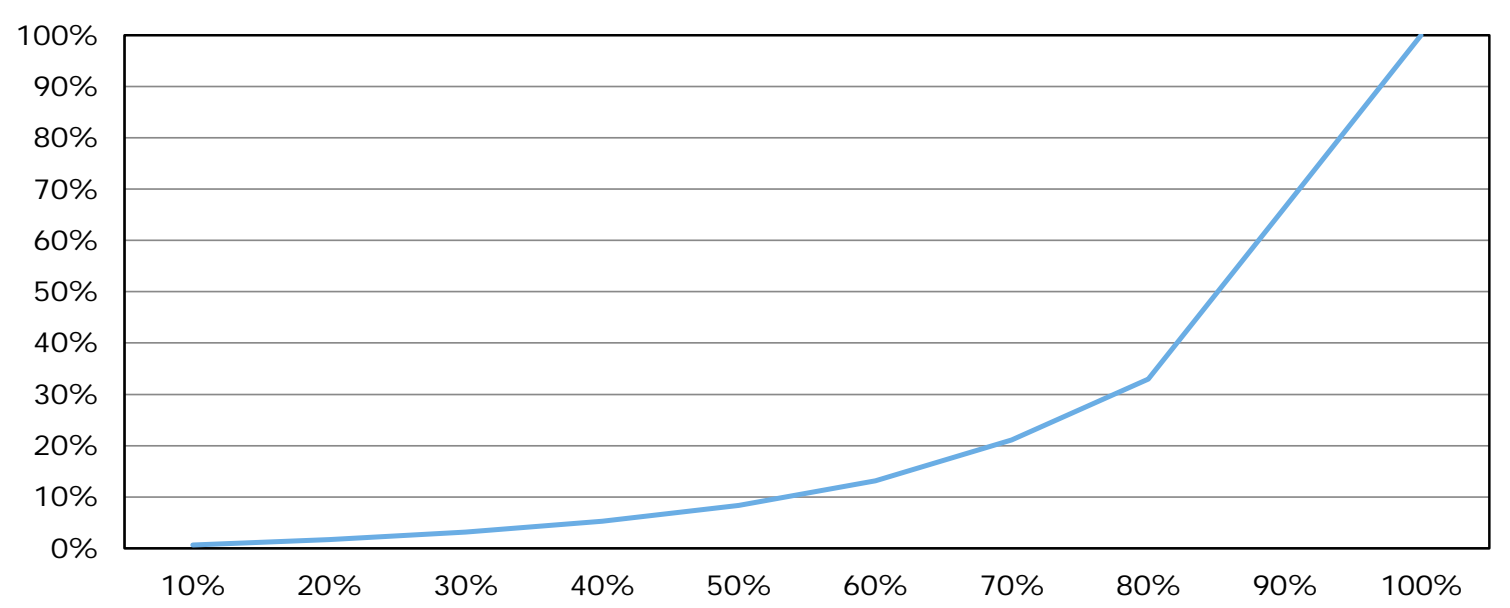

Figure B1.4 Fictitious distribution of payments to farms in Denmark based on a uniform hectare payment, 2015

Source: EC (2013) and the Eurostat Farm Structure Survey (FSS); adaptation by Wageningen Economic Research. 
Distribution of direct payments based on a uniform hectare payment over farms in Germany

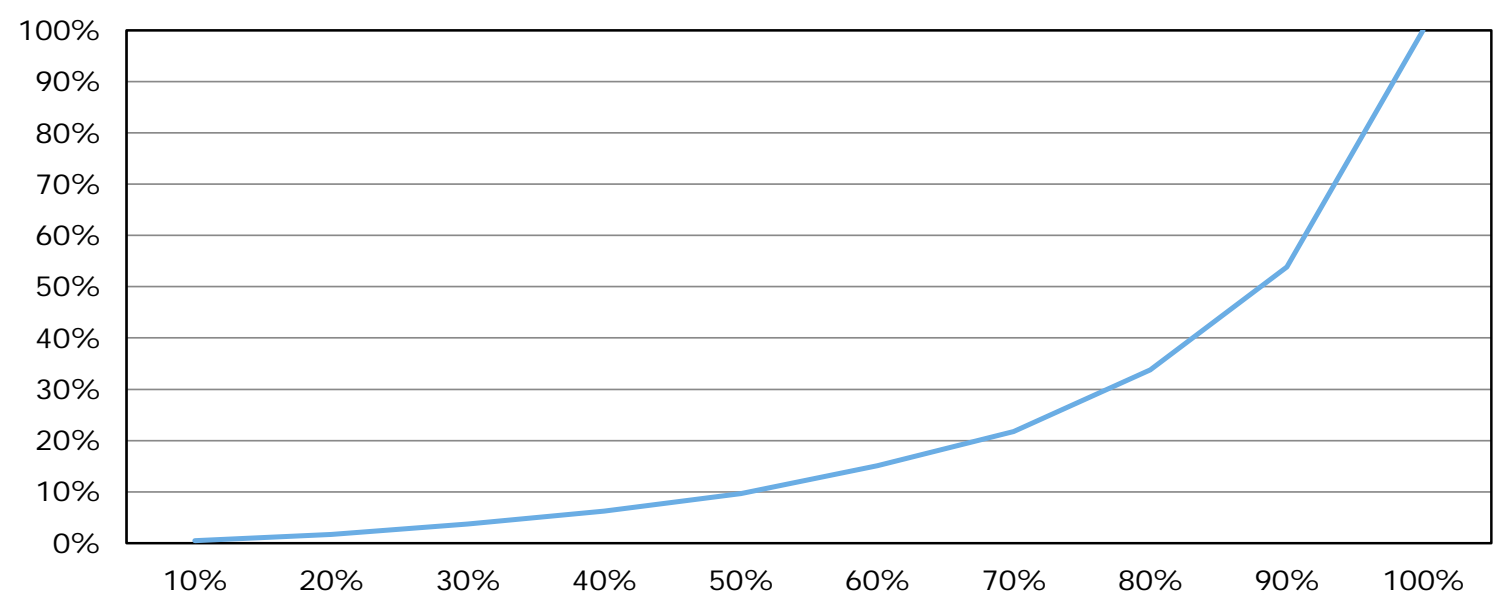

Figure B1.5 Fictitious distribution of payments to farms in Germany based on a uniform hectare payment, 2015

Source: EC (2013) and the Eurostat Farm Structure Survey (FSS); adaptation by Wageningen Economic Research.

Distribution of direct payments based on a uniform hectare payment over farms in Estonia

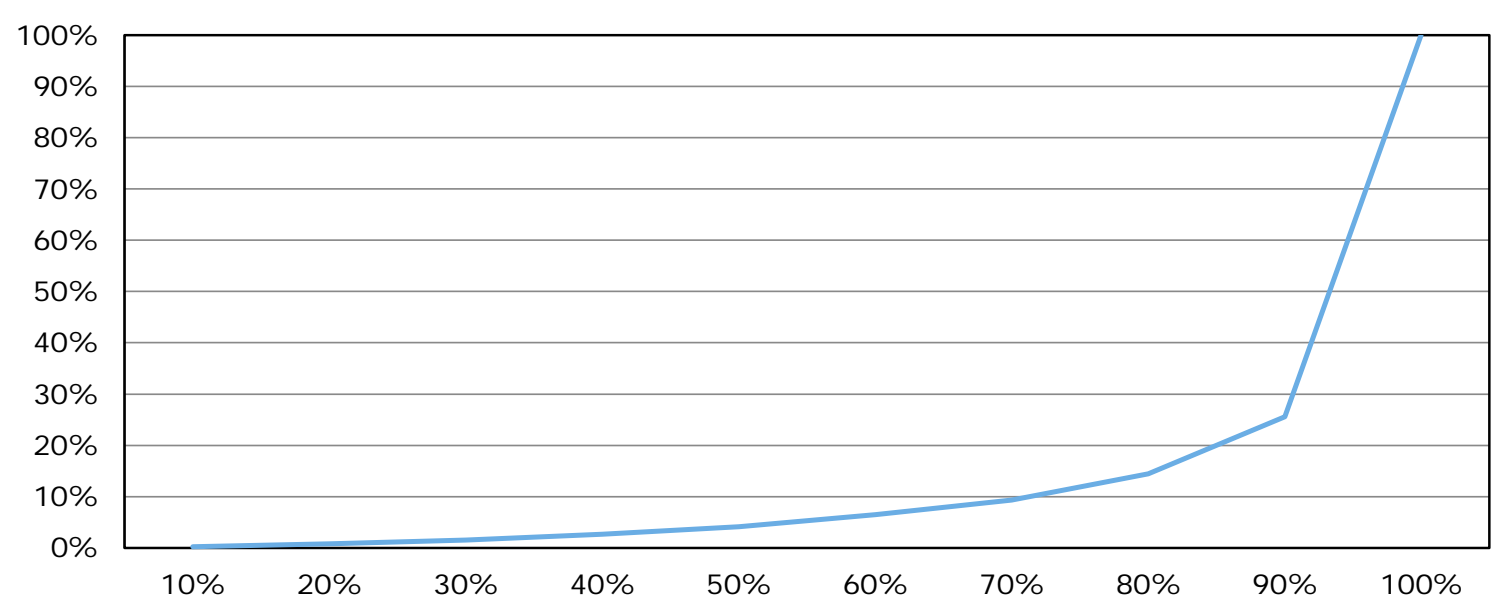

Figure B1.6 Fictitious distribution of payments to farms in Estonia based on a uniform hectare payment, 2015

Source: EC (2013) and the Eurostat Farm Structure Survey (FSS); adaptation by Wageningen Economic Research. 
Distribution of direct payments based on a uniform hectare payment over farms in Ireland

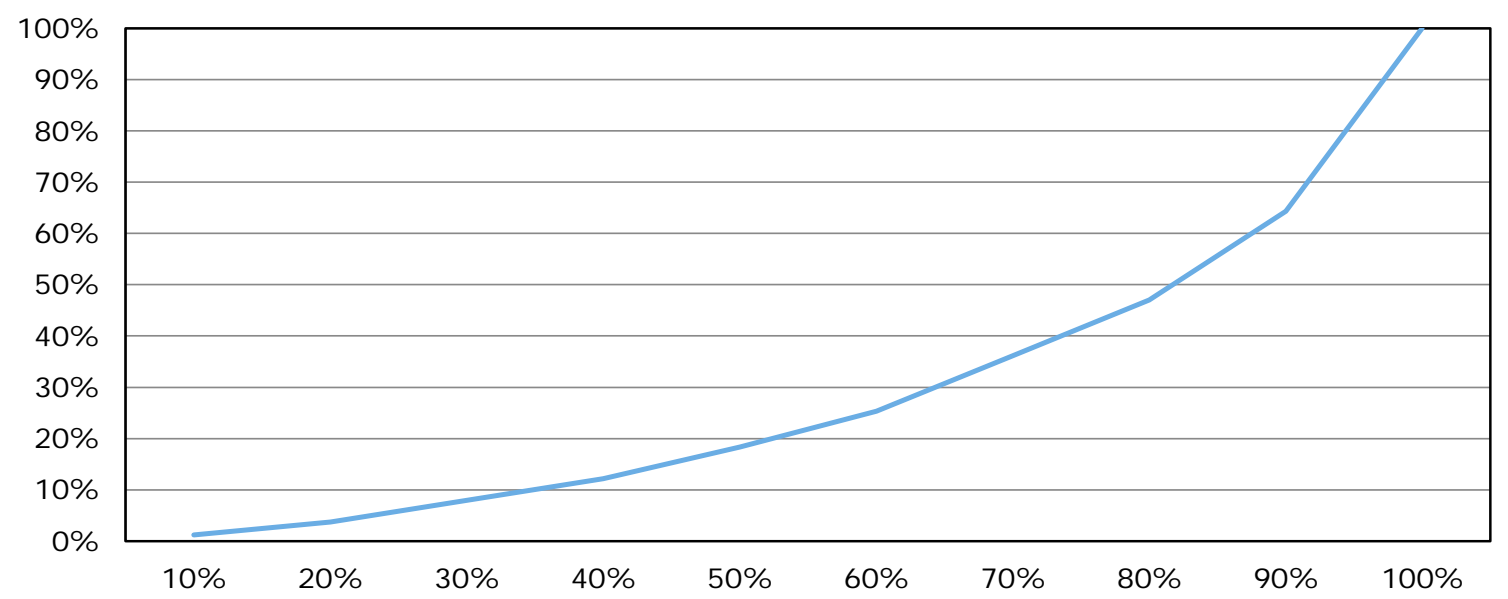

Figure B1.7 Fictitious distribution of payments to farms in I reland based on a uniform hectare payment, 2015

Source: EC (2013) and the Eurostat Farm Structure Survey (FSS); adaptation by Wageningen Economic Research.

Distribution of direct payments based on a uniform hectare payment over farms in Greece

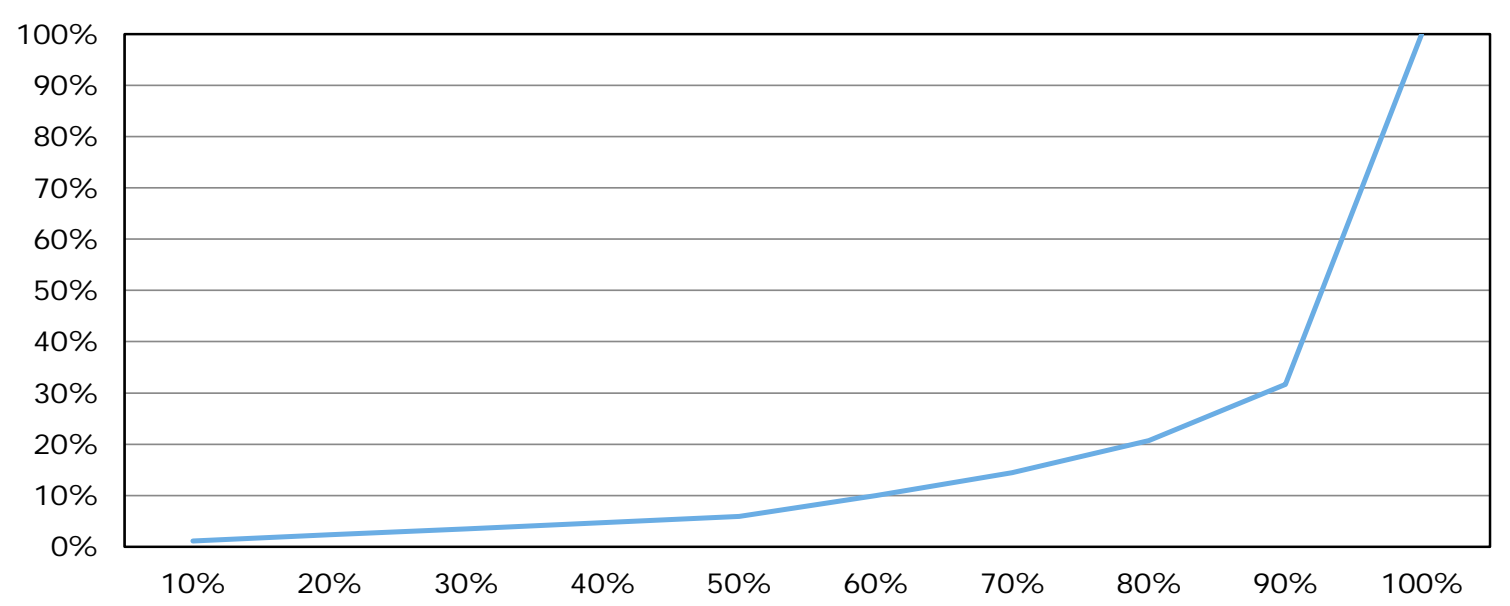

Figure B1.8 Fictitious distribution of payments to farms in Greece based on a uniform hectare payment, 2015

Source: EC (2013) and the Eurostat Farm Structure Survey (FSS); adaptation by Wageningen Economic Research. 
Distribution of direct payments based on a uniform hectare payment over farms in Spain

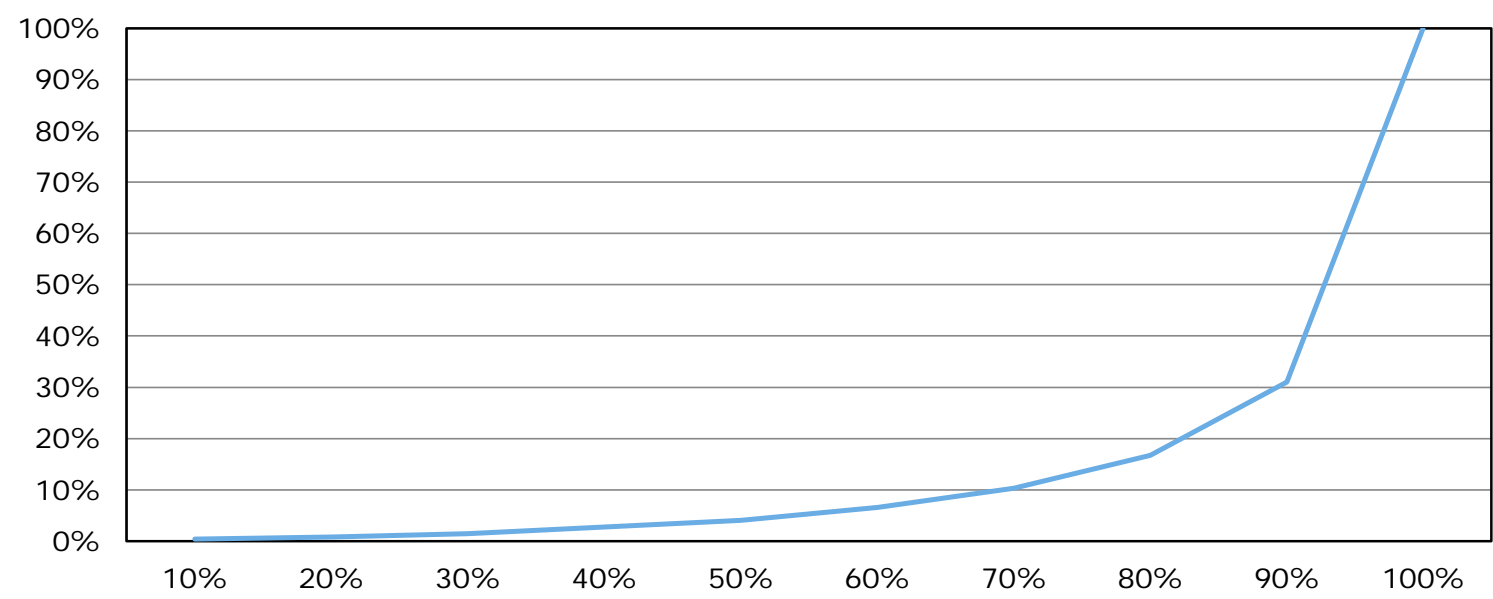

Figure B1.9 Fictitious distribution of payments to farms in Spain based on a uniform hectare payment, 2015

Source: EC (2013) and the Eurostat Farm Structure Survey (FSS); adaptation by Wageningen Economic Research.

Distribution of direct payments based on a uniform hectare payment over farms in France

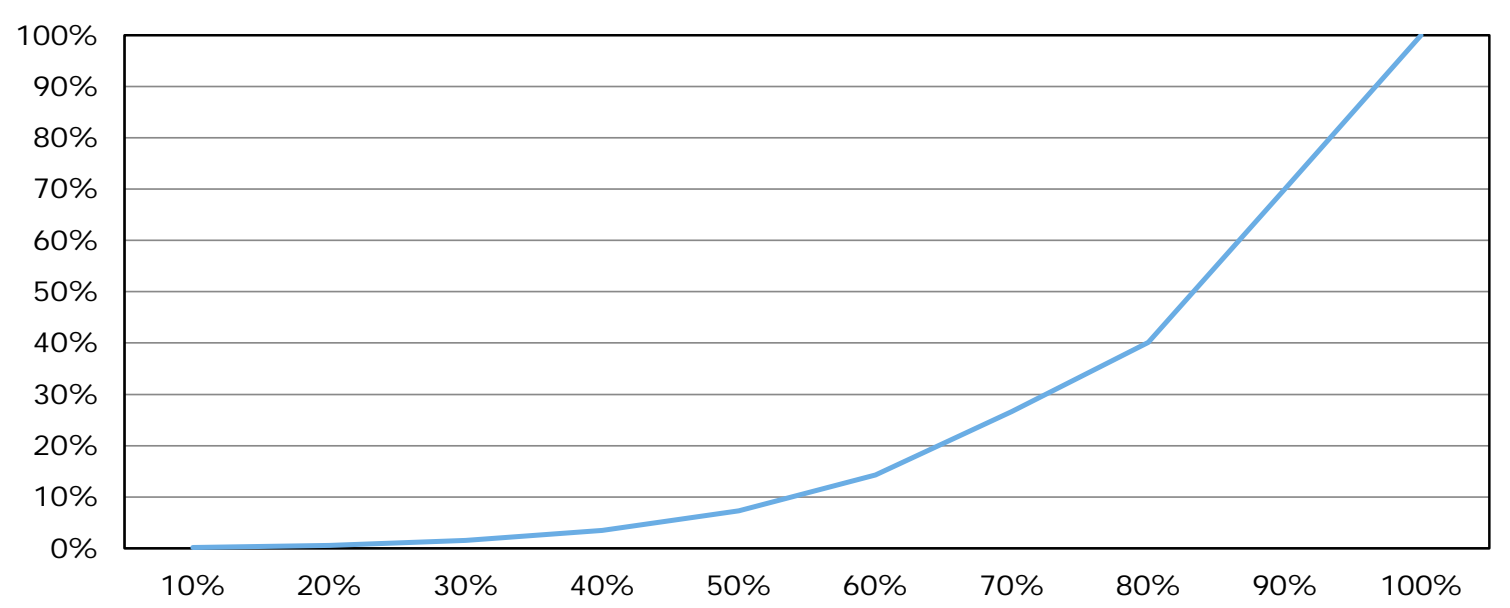

Figure B1.10 Fictitious distribution of payments to farms in France based on a uniform hectare payment, 2015

Source: EC (2013) and the Eurostat Farm Structure Survey (FSS); adaptation by Wageningen Economic Research. 
Distribution of direct payments based on a uniform hectare payment over farms in Croatia

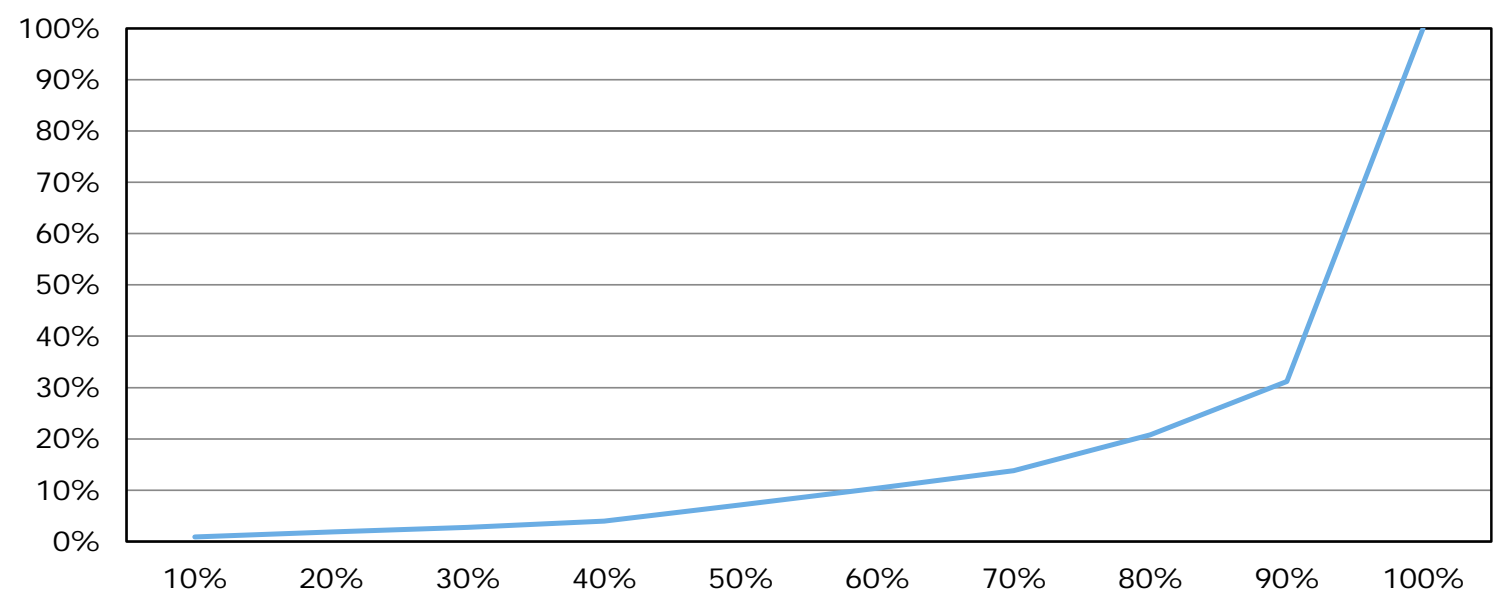

Figure B1.11 Fictitious distribution of payments to farms in Croatia based on a uniform hectare payment, 2015

Source: EC (2013) and the Eurostat Farm Structure Survey (FSS); adaptation by Wageningen Economic Research.

Distribution of direct payments based on a uniform hectare payment over farms in Italy

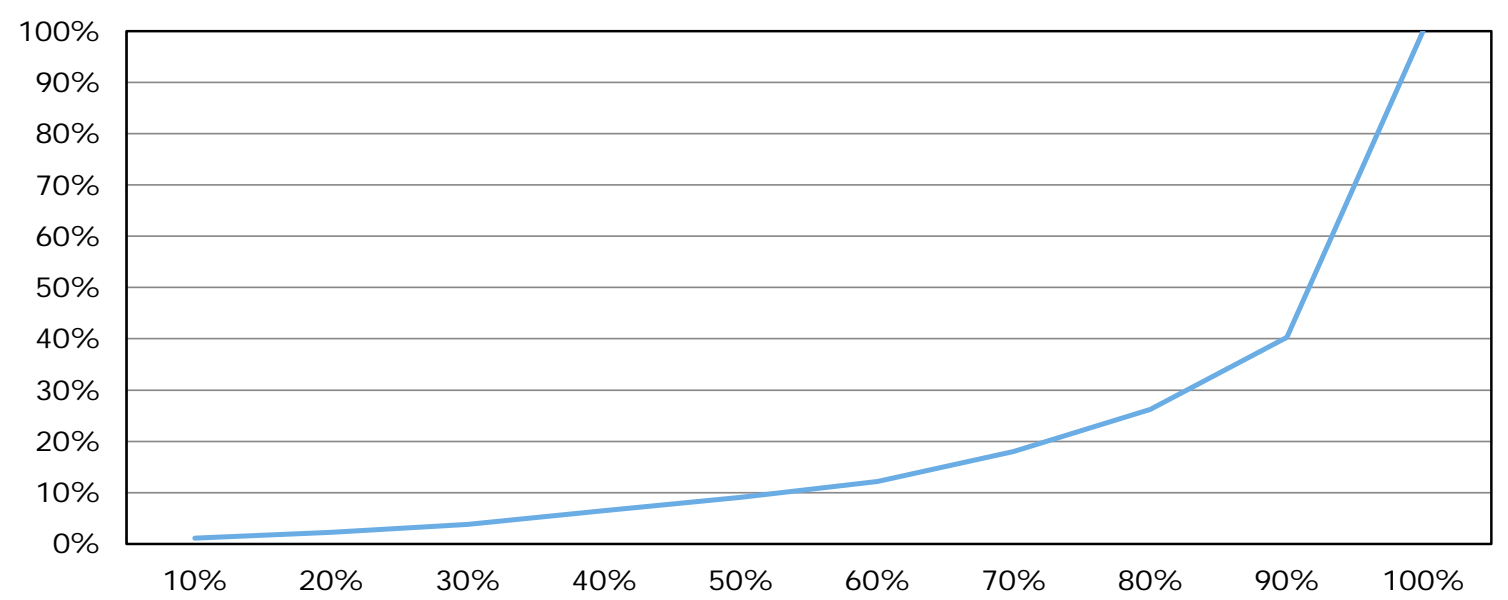

Figure B1.12 Fictitious distribution of payments to farms in I taly based on a uniform hectare payment, 2015

Source: EC (2013) and the Eurostat Farm Structure Survey (FSS); adaptation by Wageningen Economic Research. 
Distribution of direct payments based on a uniform hectare payment over farms in Cyprus

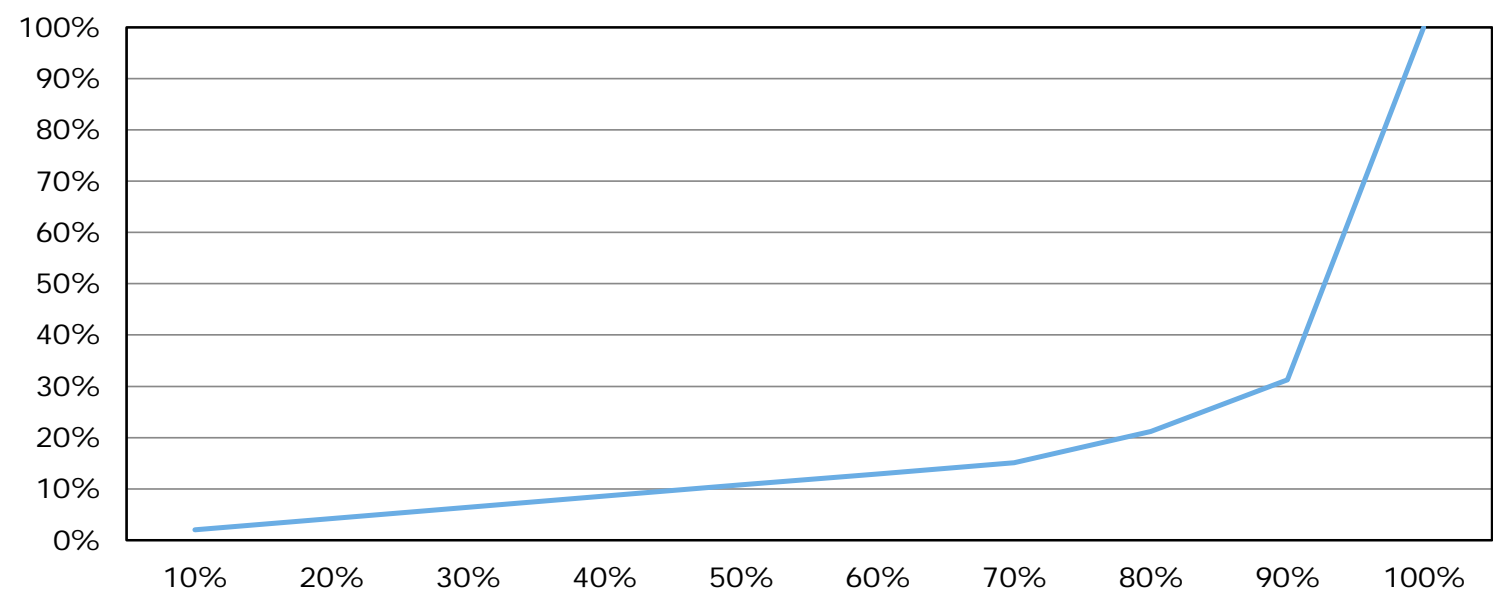

Figure B1.13 Fictitious distribution of payments to farms in Cyprus based on a uniform hectare payment, 2015

Source: EC (2013) and the Eurostat Farm Structure Survey (FSS); adaptation by Wageningen Economic Research.

Distribution of direct payments based on a uniform hectare payment over farms in Latvia

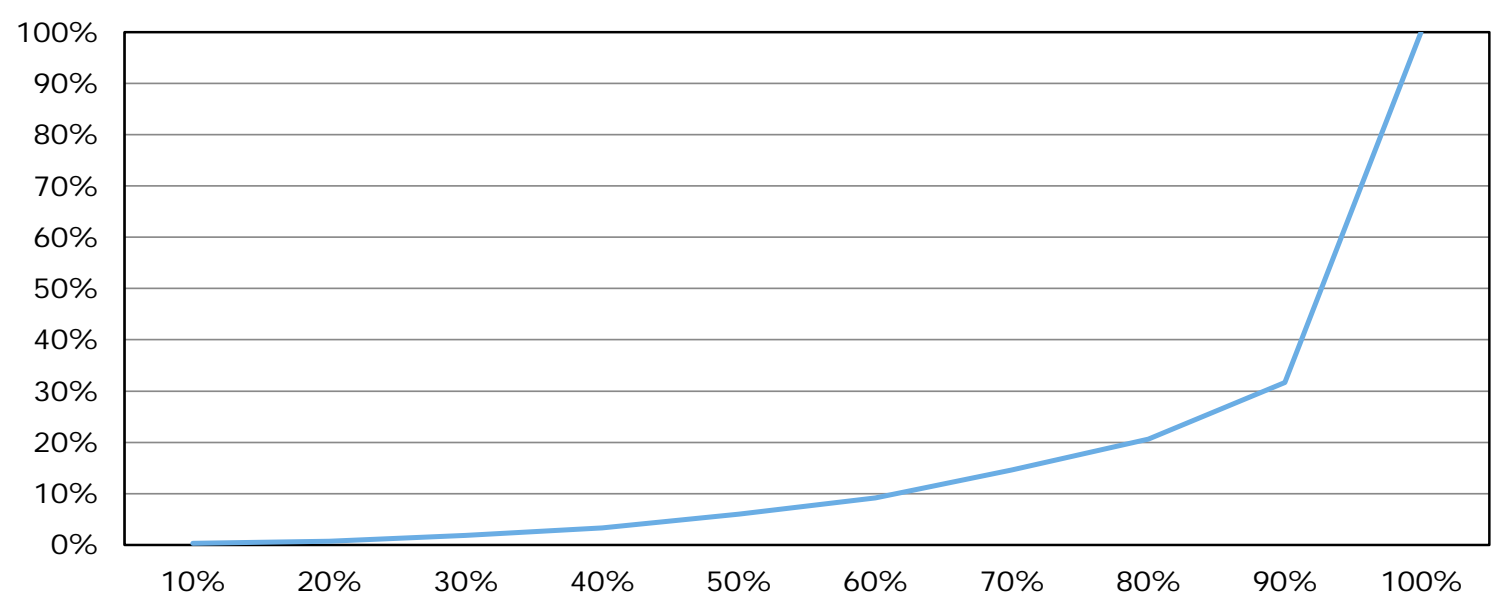

Figure B1.14 Fictitious distribution of payments to farms in Latvia based on a uniform hectare payment, 2015

Source: EC (2013) and the Eurostat Farm Structure Survey (FSS); adaptation by Wageningen Economic Research. 
Distribution of direct payments based on a uniform hectare payment over farms in Lithuania

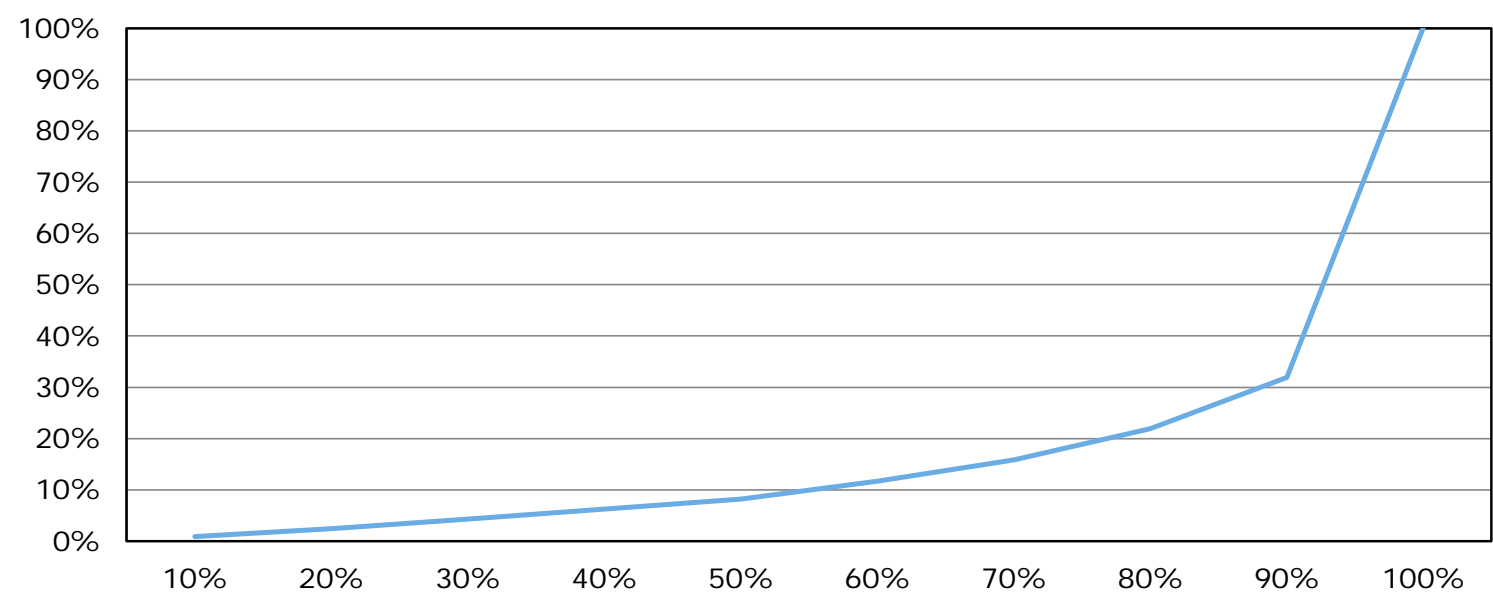

Figure B1.15 Fictitious distribution of payments to farms in Lithuania based on a uniform hectare payment, 2015

Source: EC (2013) and the Eurostat Farm Structure Survey (FSS); adaptation by Wageningen Economic Research.

Distribution of direct payments based on a uniform hectare payment over farms in Luxembourg

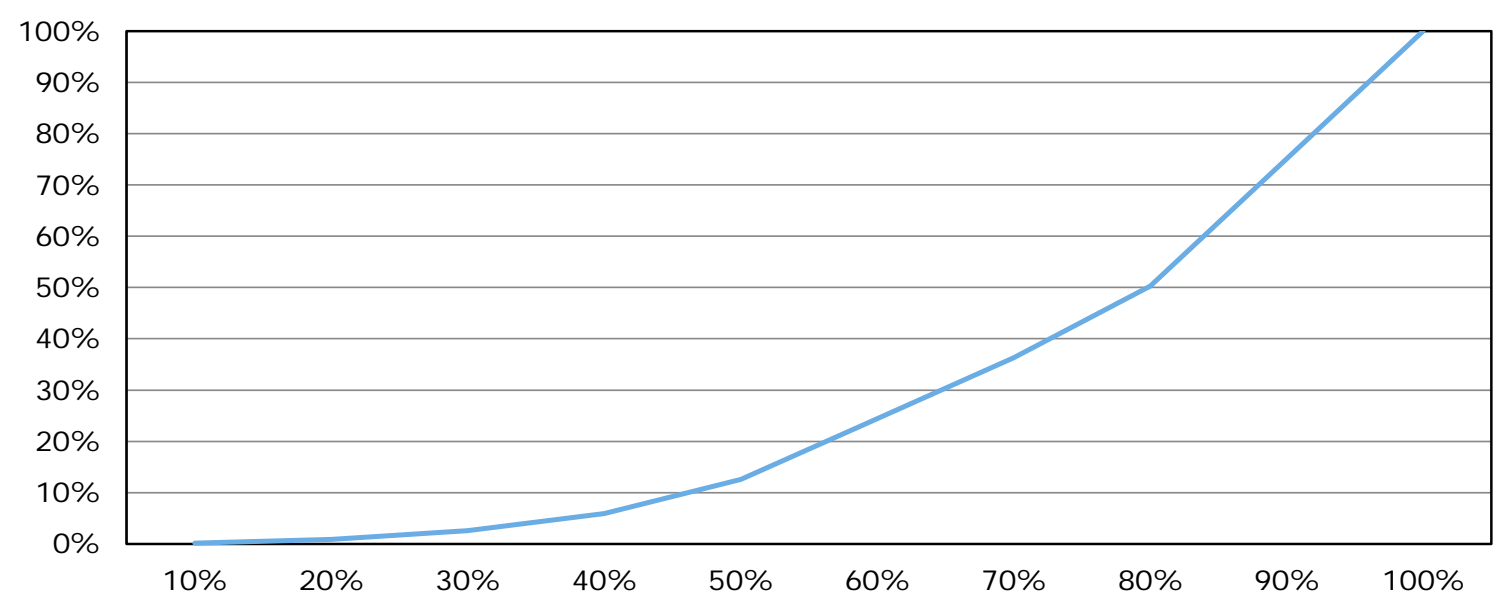

Figure B1.16 Fictitious distribution of payments to farms in Luxembourg based on a uniform hectare payment, 2015

Source: EC (2013) and the Eurostat Farm Structure Survey (FSS); adaptation by Wageningen Economic Research. 
Distribution of direct payments based on a uniform hectare payment over farms in Hungary

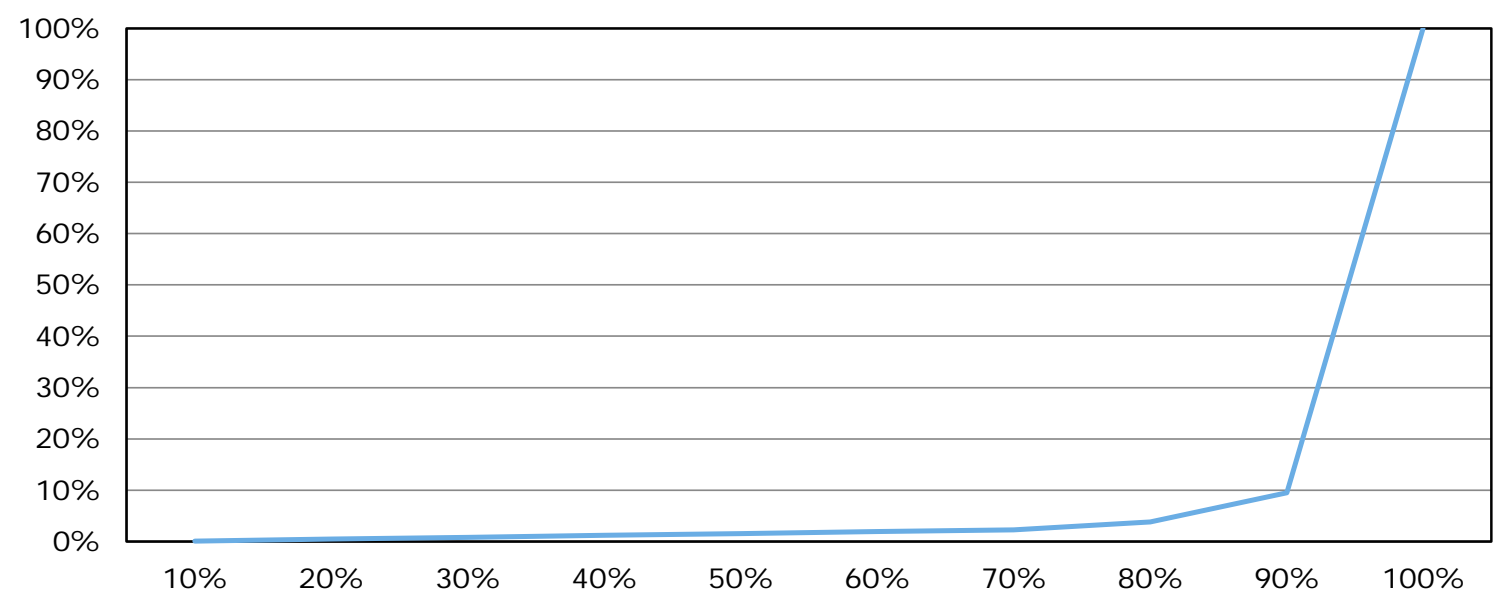

Figure B1.17 Fictitious distribution of payments to farms in Hungary based on a uniform hectare payment, 2015

Source: EC (2013) and the Eurostat Farm Structure Survey (FSS); adaptation by Wageningen Economic Research.

Distribution of direct payments based on a uniform hectare payment over farms in Malta

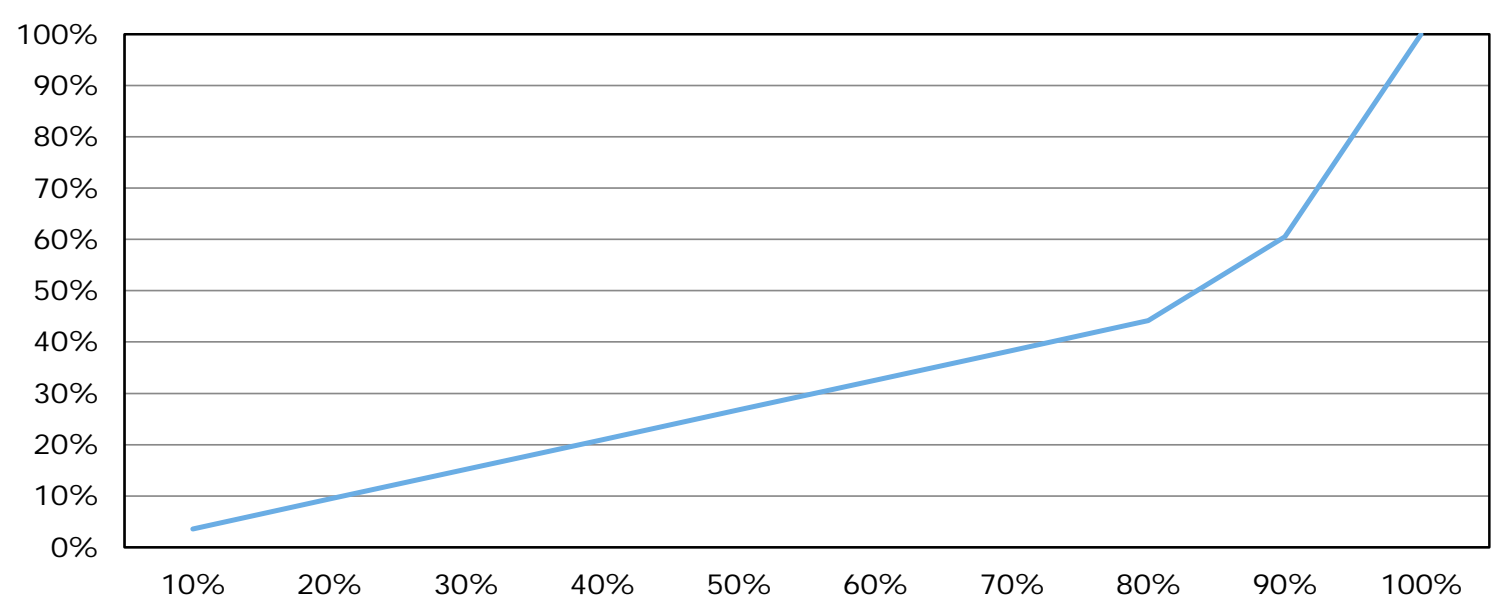

Figure B1.18 Fictitious distribution of payments to farms in Malta based on a uniform hectare payment, 2015

Source: EC (2013) and the Eurostat Farm Structure Survey (FSS); adaptation by Wageningen Economic Research. 
Distribution of direct payments based on a uniform hectare payment over farms in Netherlands

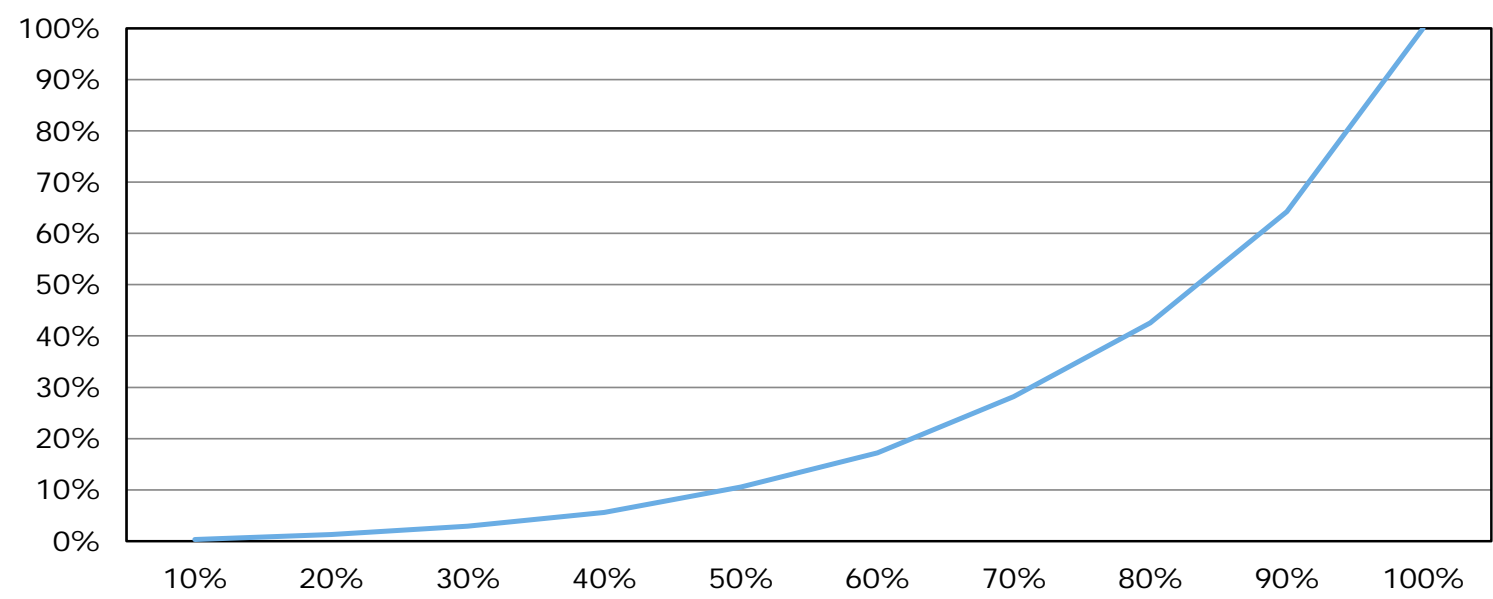

Figure B1.19 Fictitious distribution of payments to farms in the Netherlands based on a uniform hectare payment, 2015

Source: EC (2013) and the Eurostat Farm Structure Survey (FSS); adaptation by Wageningen Economic Research.

Distribution of direct payments based on a uniform hectare payment over farms in Austria

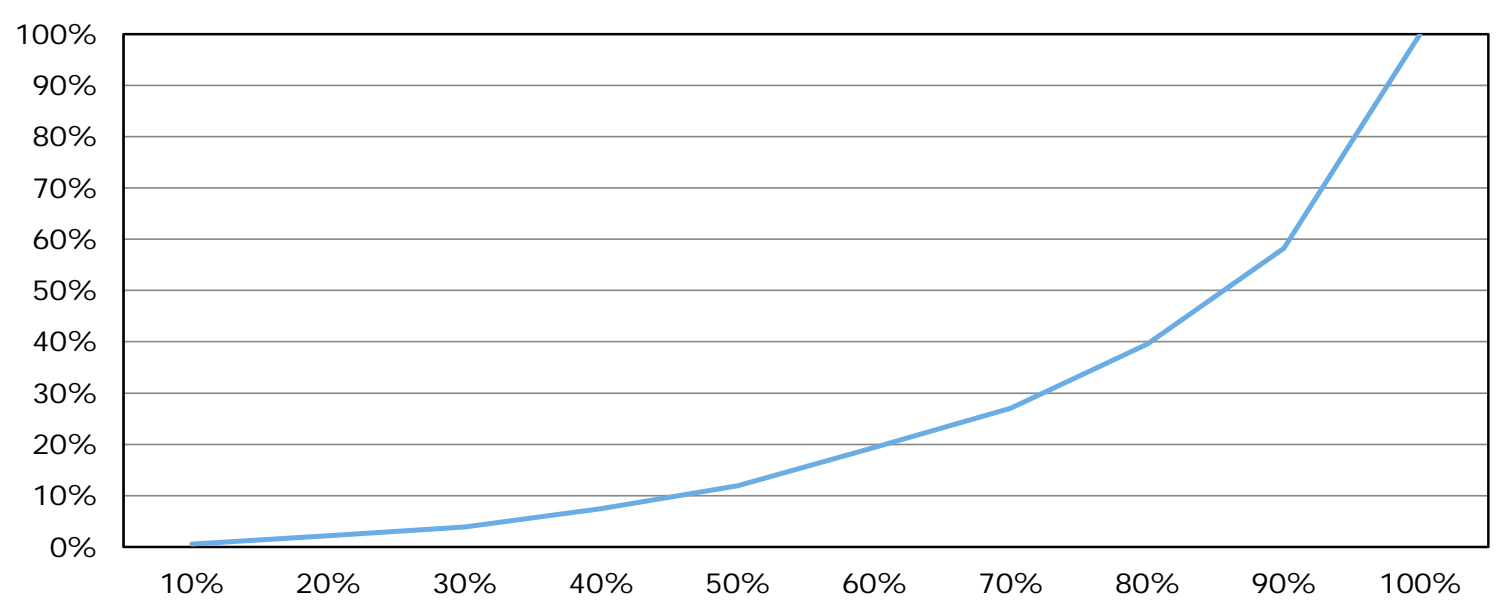

Figure B1.20 Fictitious distribution of payments to farms in Austria based on a uniform hectare payment, 2015

Source: EC (2013) and the Eurostat Farm Structure Survey (FSS); adaptation by Wageningen Economic Research. 
Distribution of direct payments based on a uniform hectare payment over farms in Poland

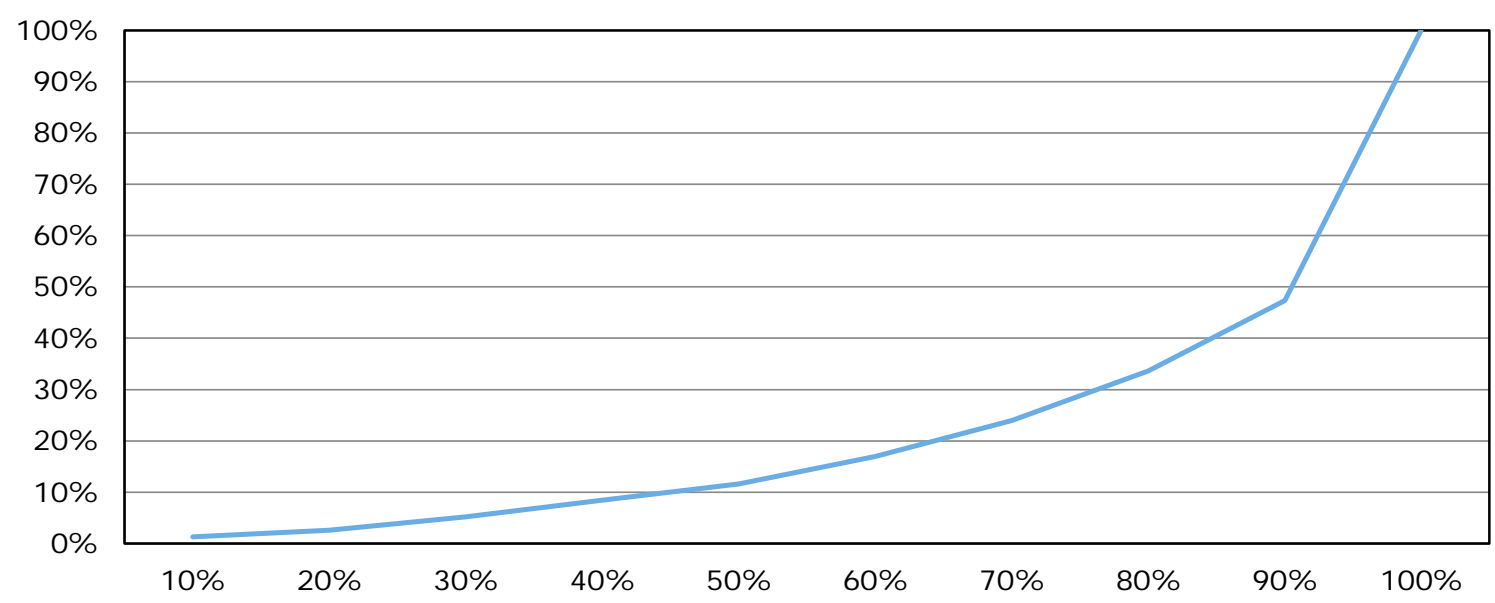

Figure B1.21 Fictitious distribution of payments to farms in Poland based on a uniform hectare payment, 2015

Source: EC (2013) and the Eurostat Farm Structure Survey (FSS); adaptation by Wageningen Economic Research.

Distribution of direct payments based on a uniform hectare payment over farms in Portugal

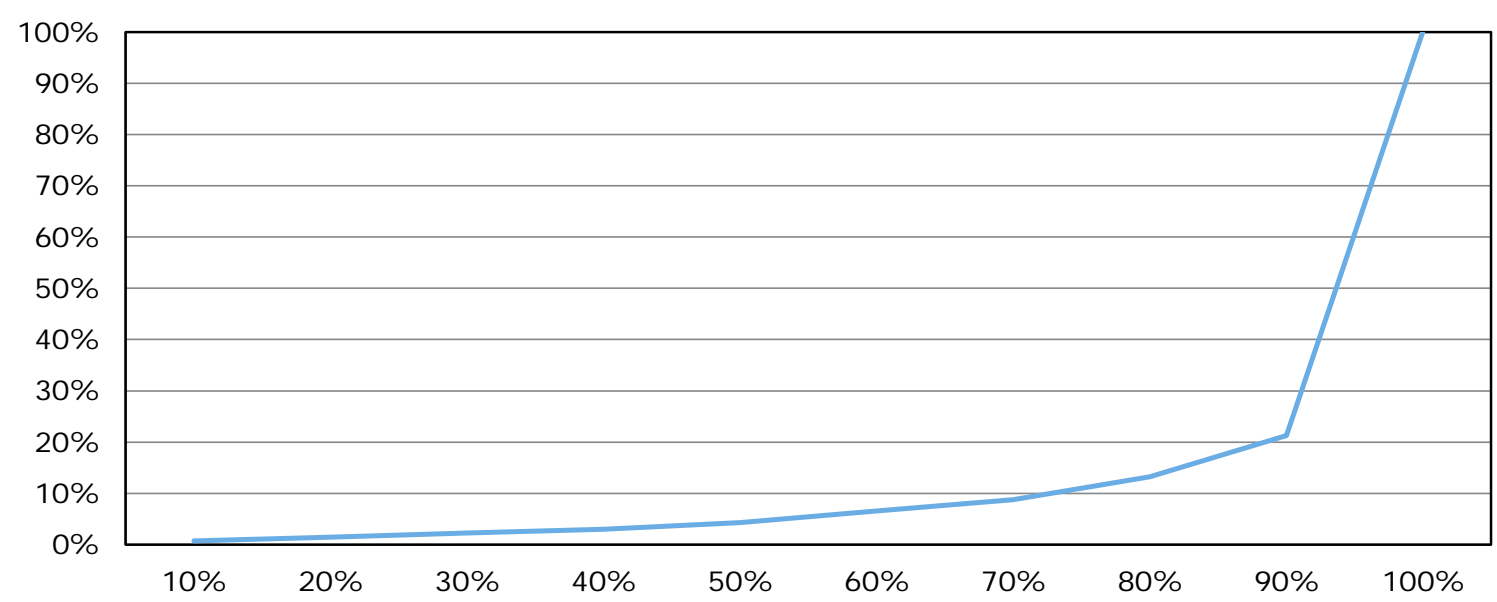

Figure B1.22 Fictitious distribution of payments to farms in Portugal based on a uniform hectare payment, 2015

Source: EC (2013) and the Eurostat Farm Structure Survey (FSS); adaptation by Wageningen Economic Research. 
Distribution of direct payments based on a uniform hectare payment over farms in Romania

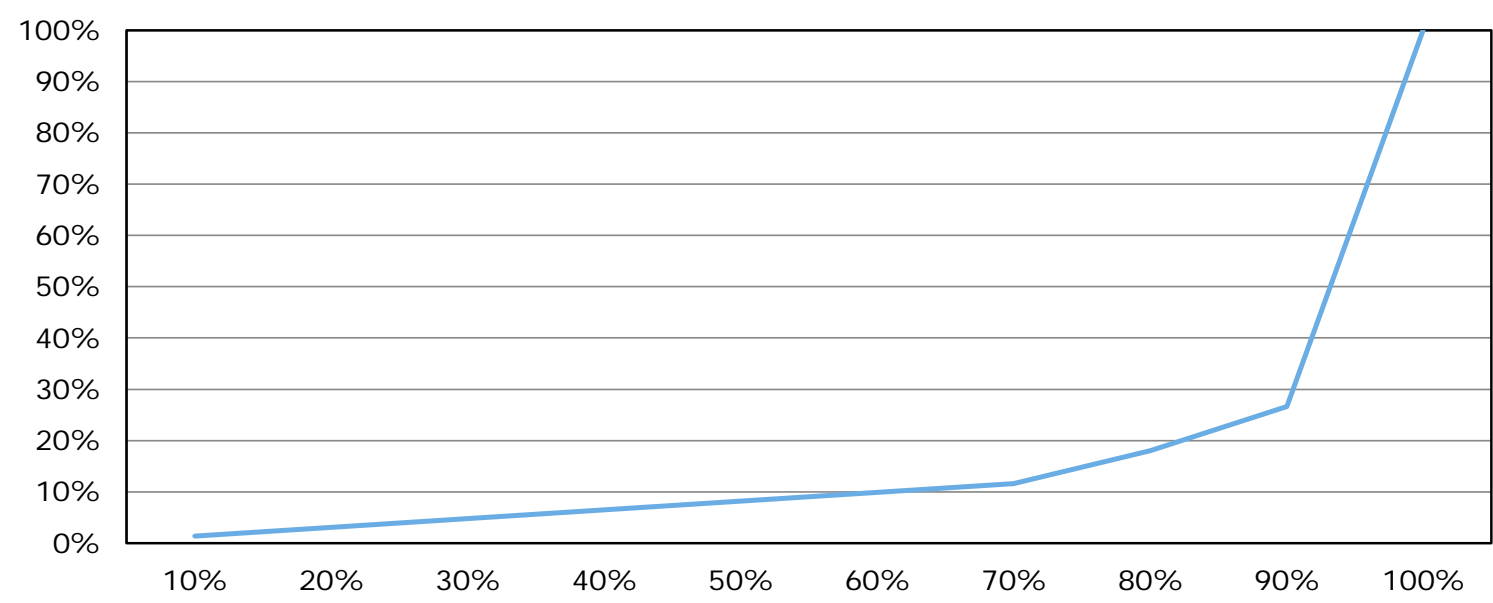

Figure B1.23 Fictitious distribution of payments to farms in Romania based on a uniform hectare payment, 2015

Source: EC (2013) and the Eurostat Farm Structure Survey (FSS); adaptation by Wageningen Economic Research.

Distribution of direct payments based on a uniform hectare payment over farms in Slovenia

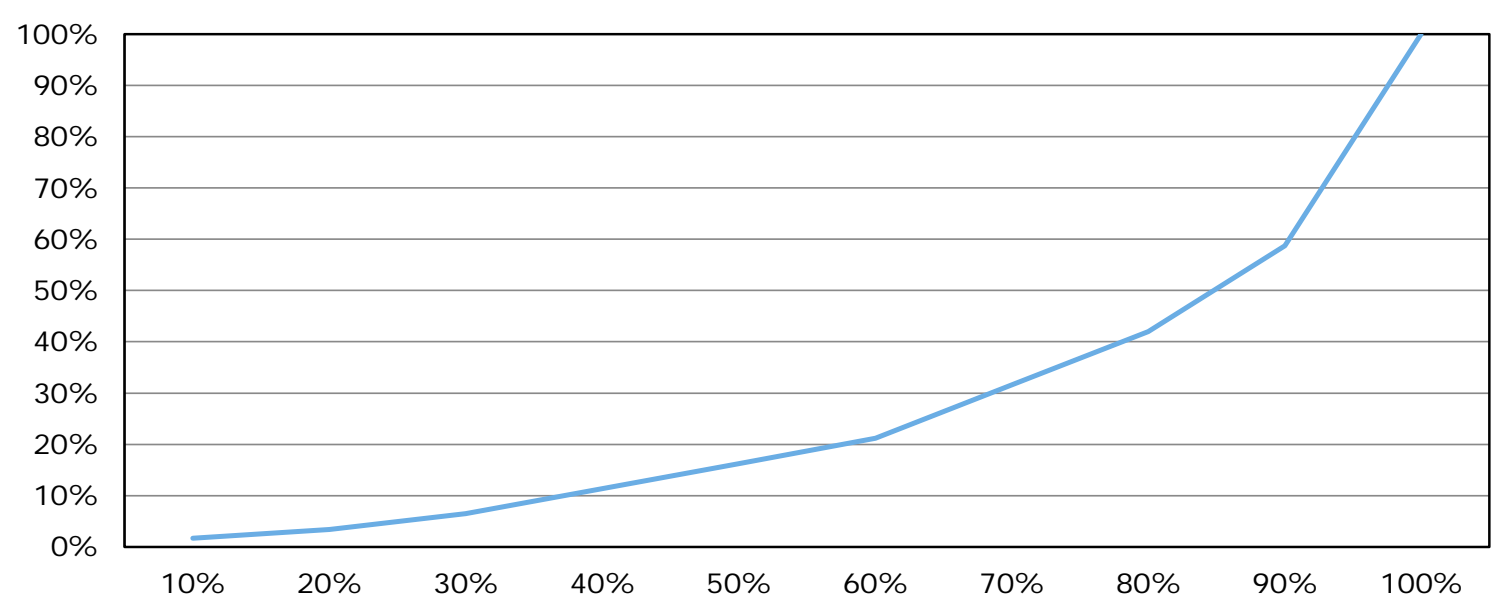

Figure B1.24 Fictitious distribution of payments to farms in Slovenia based on a uniform hectare payment, 2015

Source: EC (2013) and the Eurostat Farm Structure Survey (FSS); adaptation by Wageningen Economic Research. 
Distribution of direct payments based on a uniform hectare payment over farms in Slovakia

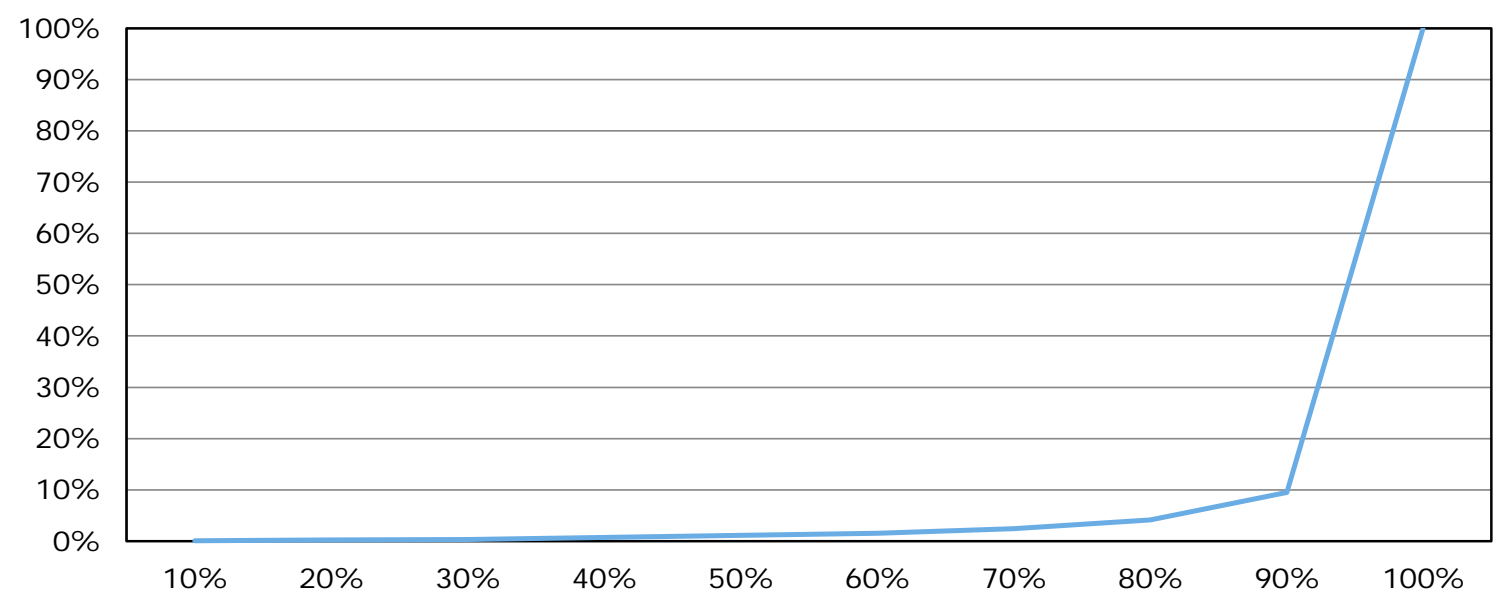

Figure B1.25 Fictitious distribution of payments to farms in Slovakia based on a uniform hectare payment, 2015

Source: EC (2013) and the Eurostat Farm Structure Survey (FSS); adaptation by Wageningen Economic Research.

Distribution of direct payments based on a uniform hectare payment over farms in Finland

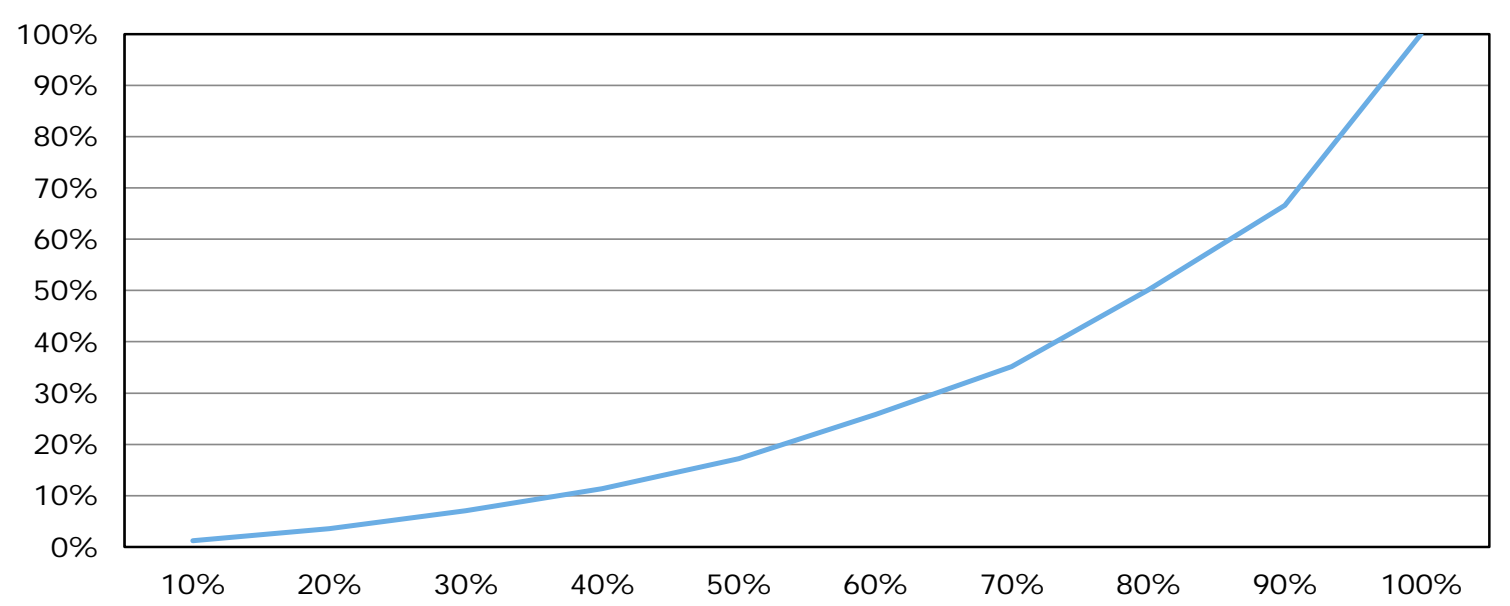

Figure B1.26 Fictitious distribution of payments to farms in Finland based on a uniform hectare payment, 2015

Source: EC (2013) and the Eurostat Farm Structure Survey (FSS); adaptation by Wageningen Economic Research. 
Distribution of direct payments based on a uniform hectare payment over farms in Sweden

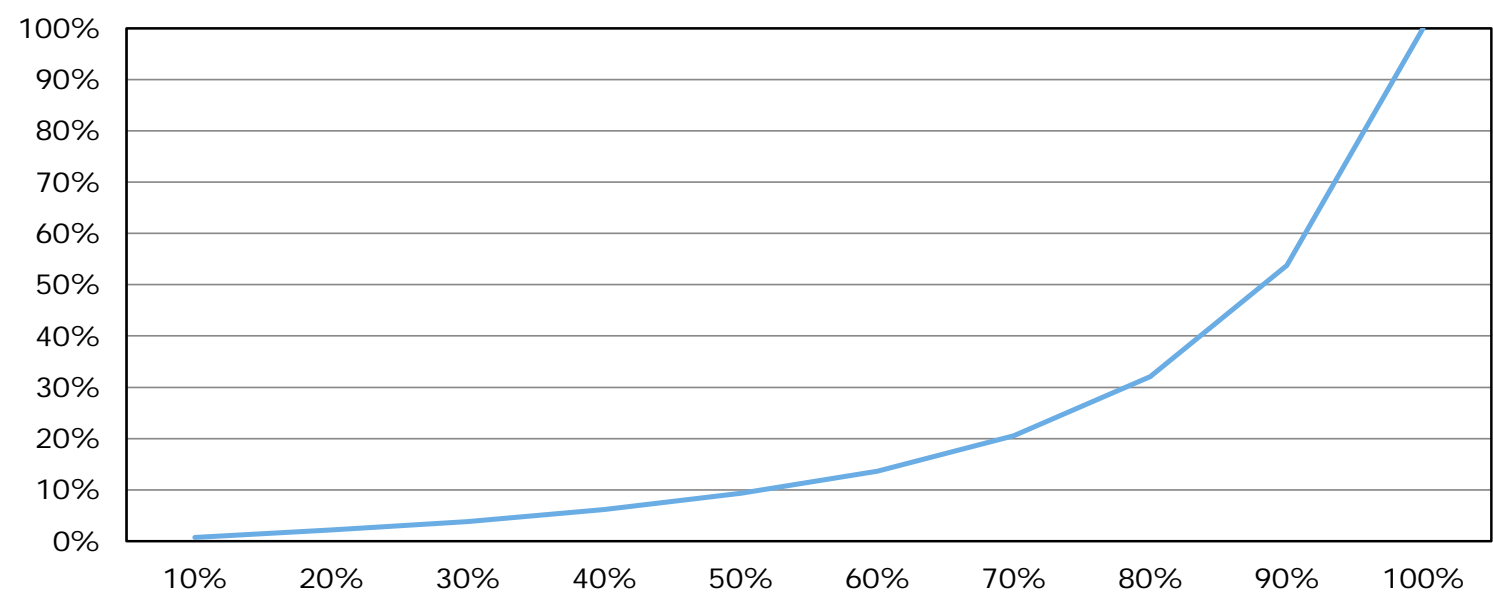

Figure B1.27 Fictitious distribution of payments to farms in Sweden based on a uniform hectare payment, 2015

Source: EC (2013) and the Eurostat Farm Structure Survey (FSS); adaptation by Wageningen Economic Research.

Distribution of direct payments based on a uniform hectare payment over farms in United Kingdom

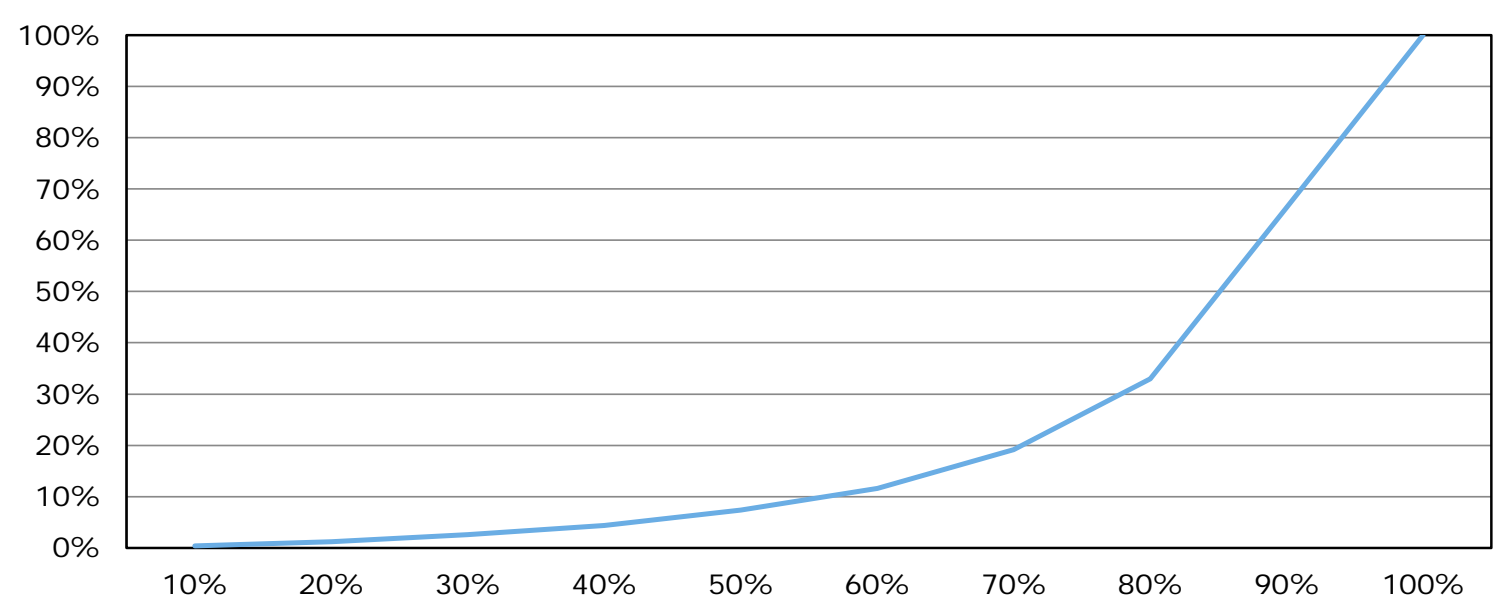

Figure B1.28 Fictitious distribution of payments to farms in the UK based on a uniform hectare payment, 2015

Source: EC (2013) and the Eurostat Farm Structure Survey (FSS); adaptation by Wageningen Economic Research. 


\section{Appendix 2 Direct payments from the first pillar of the CAP as a percentage of income per farming type in EU member countries, 2015}

Share of P1 payments in family farm income per FWU in Belgium (2015)

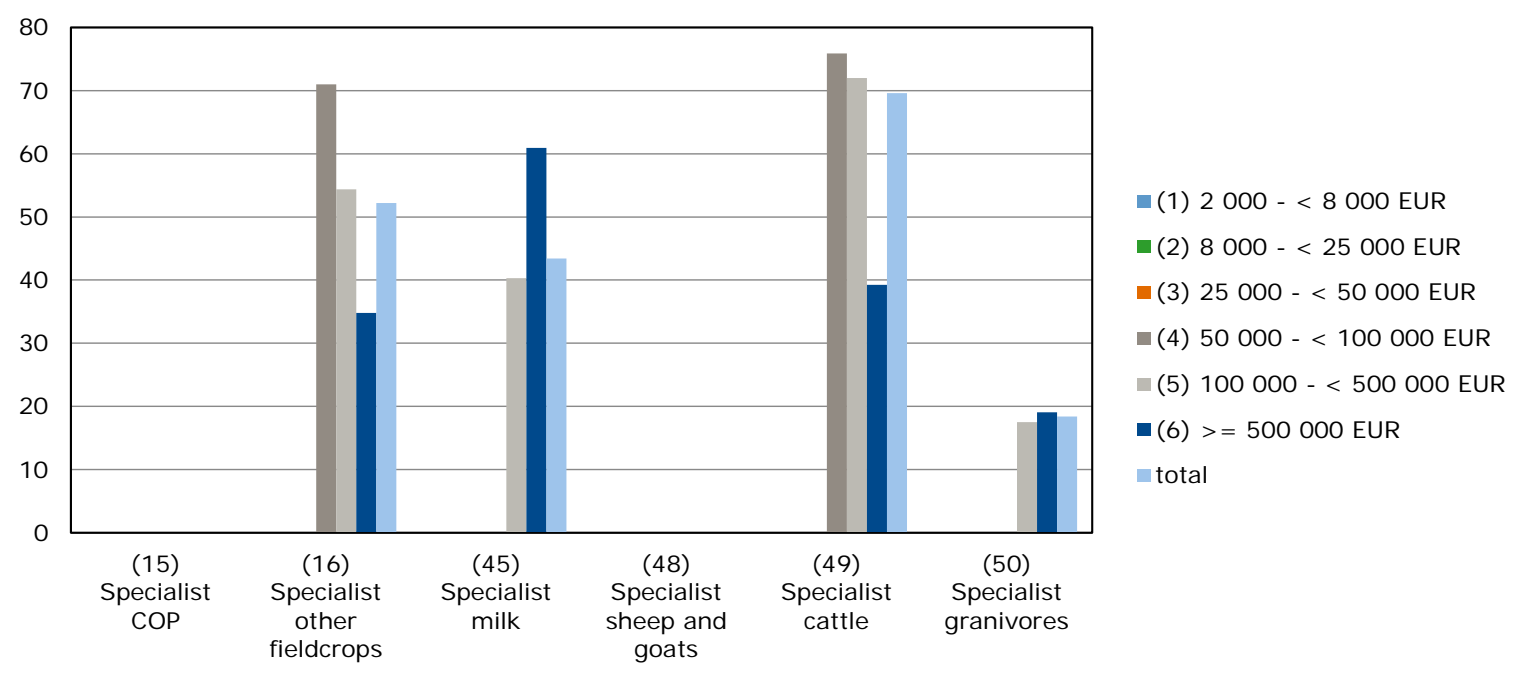

Figure B2.1 Direct payments from the first pillar of the CAP as a percentage of family farm income per family work unit for different farming types in Belgium, 2015

A missing bar indicates that no information for the relevant group can be shown due to insufficient observations. Business type (15) COP specialists are businesses that specialise in cereals, oilseed, and protein crops.

Source: FADN; adaptation by Wageningen Economic Research.

Share of P1 payments in family farm income per FWU in Bulgaria (2015)

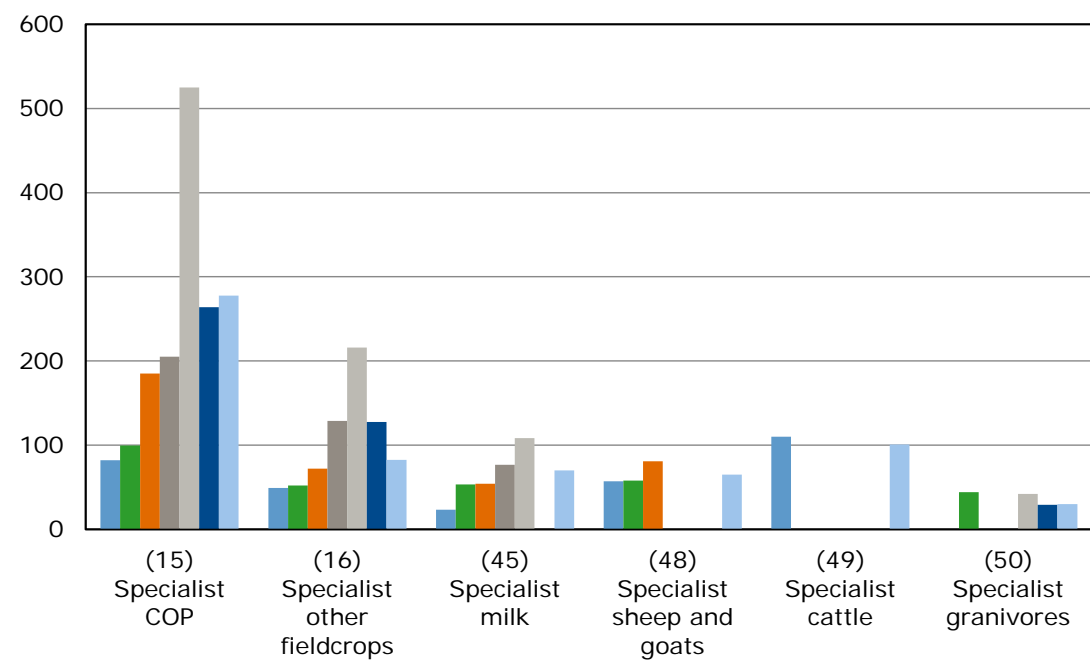

- (1) $2000-<8000$ EUR

- (2) $8000-<25000$ EUR

- (3) $25000-<50000$ EUR

- (4) $50000-<100000$ EUR

(5) $100000-<500000$ EUR

- (6) $>=500000$ EUR

total

Figure B2.2 Direct payments from the first pillar of the CAP as a percentage of family farm income per family work unit for different farming types in Bulgaria, 2015

Source and explanation: see Figure B2.1. 
Share of P1 payments in family farm income per FWU in Czech Republic (2015)

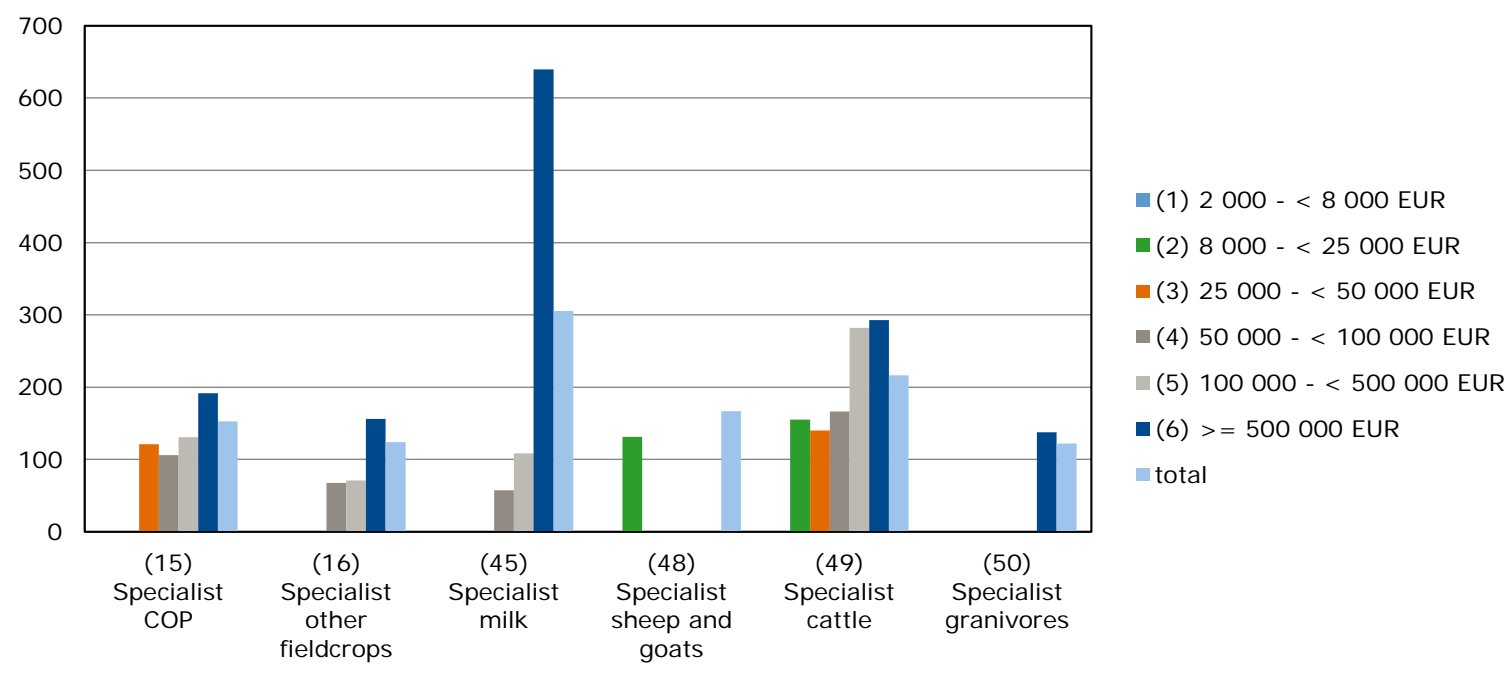

Figure B2.3 Direct payments from the first pillar of the CAP as a percentage of family farm income per family work unit for different farming types in the Czech Republic, 2015

Source and explanation: see Figure B2.1.

Share of P1 payments in family farm income per FWU in Denmark (2015)

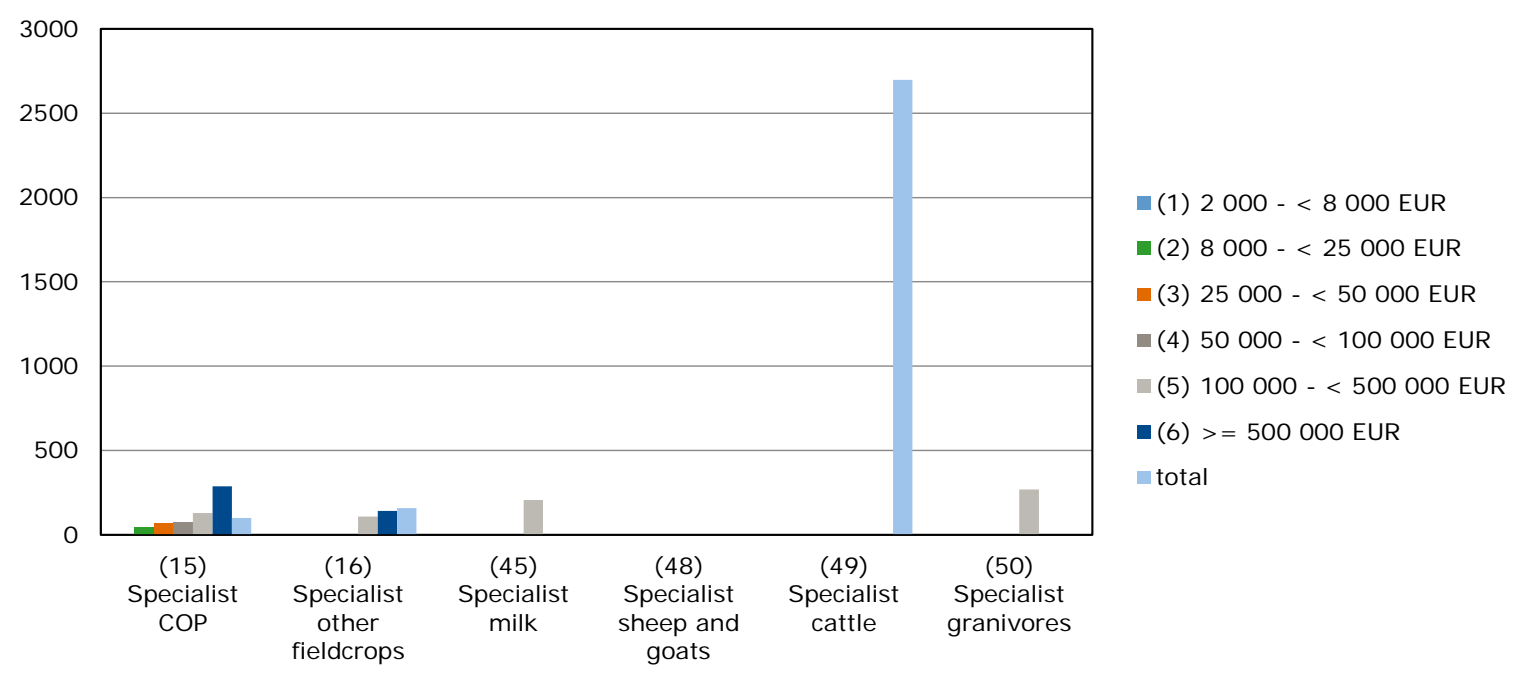

Figure B2.4 Direct payments from the first pillar of the CAP as a percentage of family farm income per family work unit for different farming types in Denmark, 2015

Source and explanation: see Figure B2.1. 


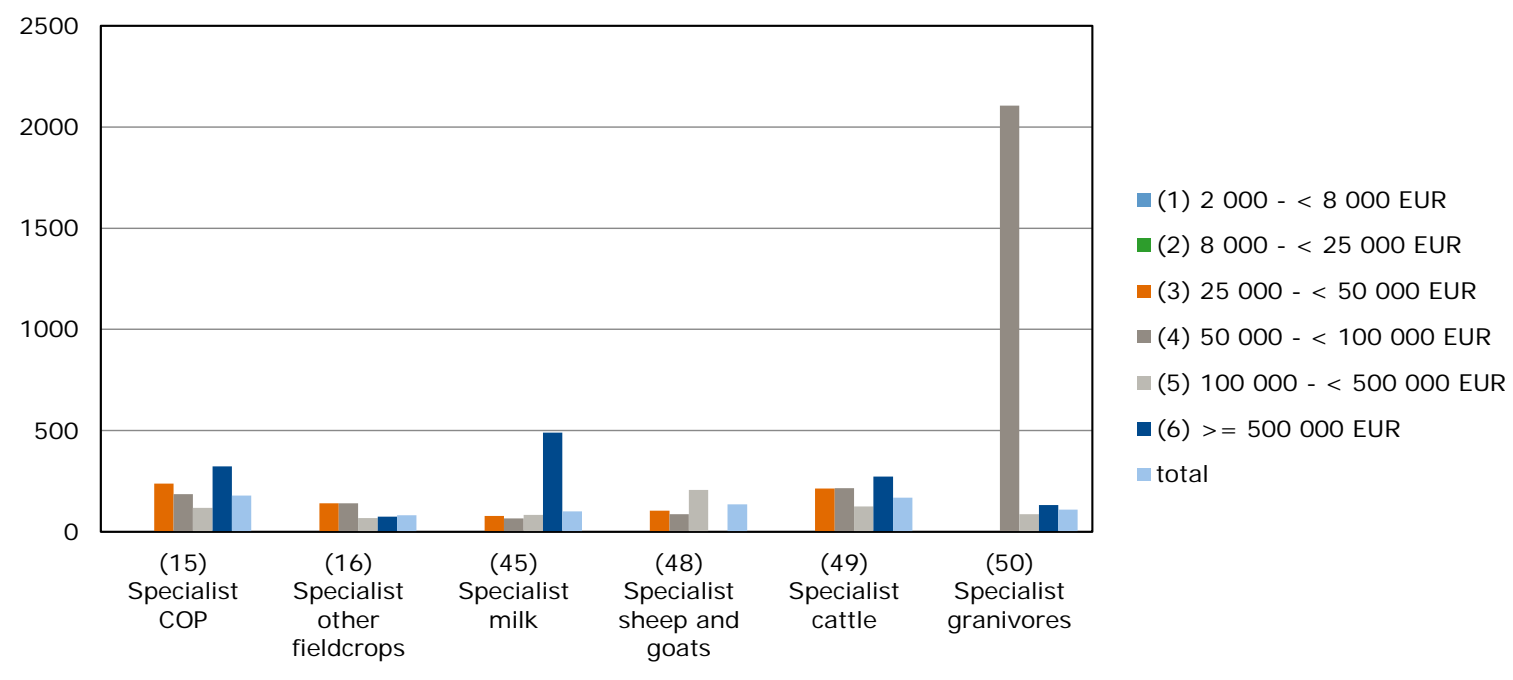

Figure B2.5 Direct payments from the first pillar of the CAP as a percentage of family farm income per family work unit for different farming types in Germany, 2015

Source and explanation: see Figure B2.1.

Share of P1 payments in family farm income per FWU in Estonia (2015)

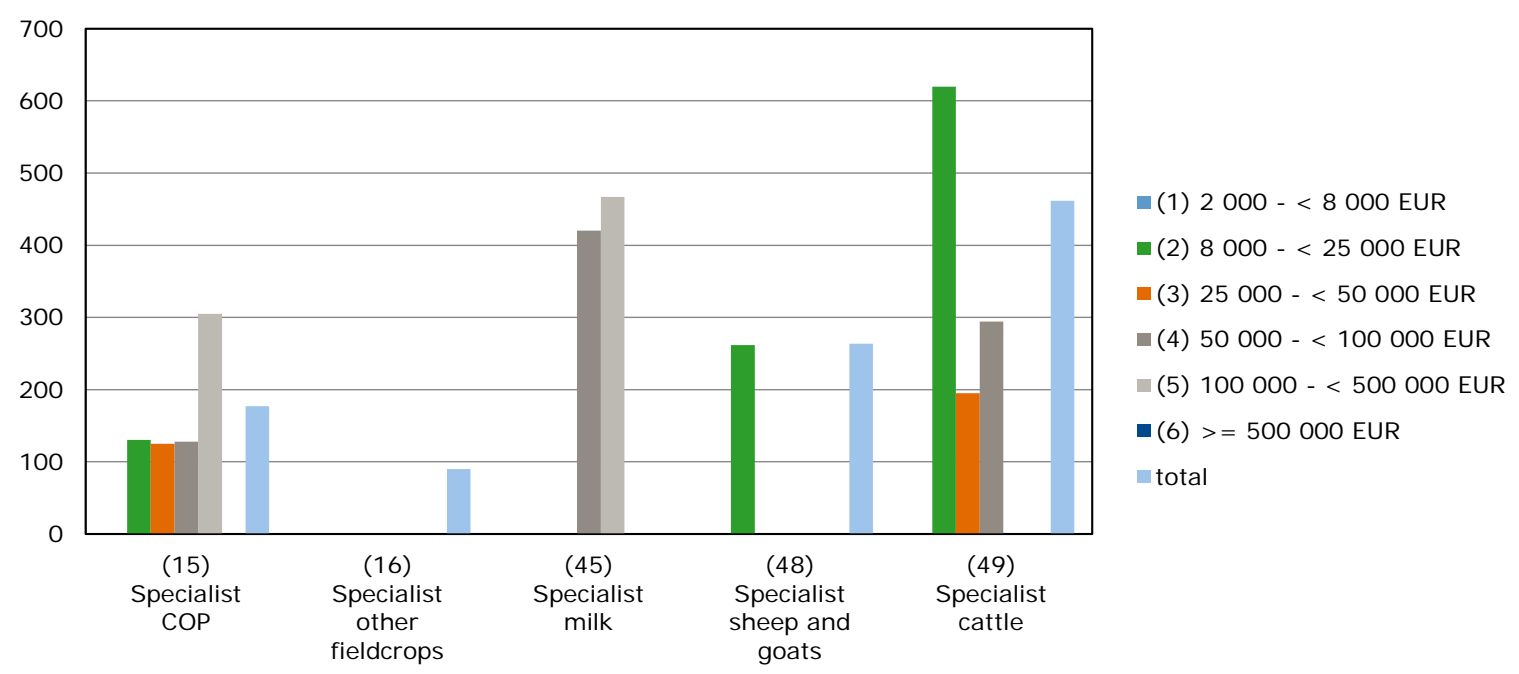

Figure B2.6 Direct payments from the first pillar of the CAP as a percentage of family farm income per family work unit for different farming types in Estonia, 2015 Source and explanation: see Figure B2.1. 


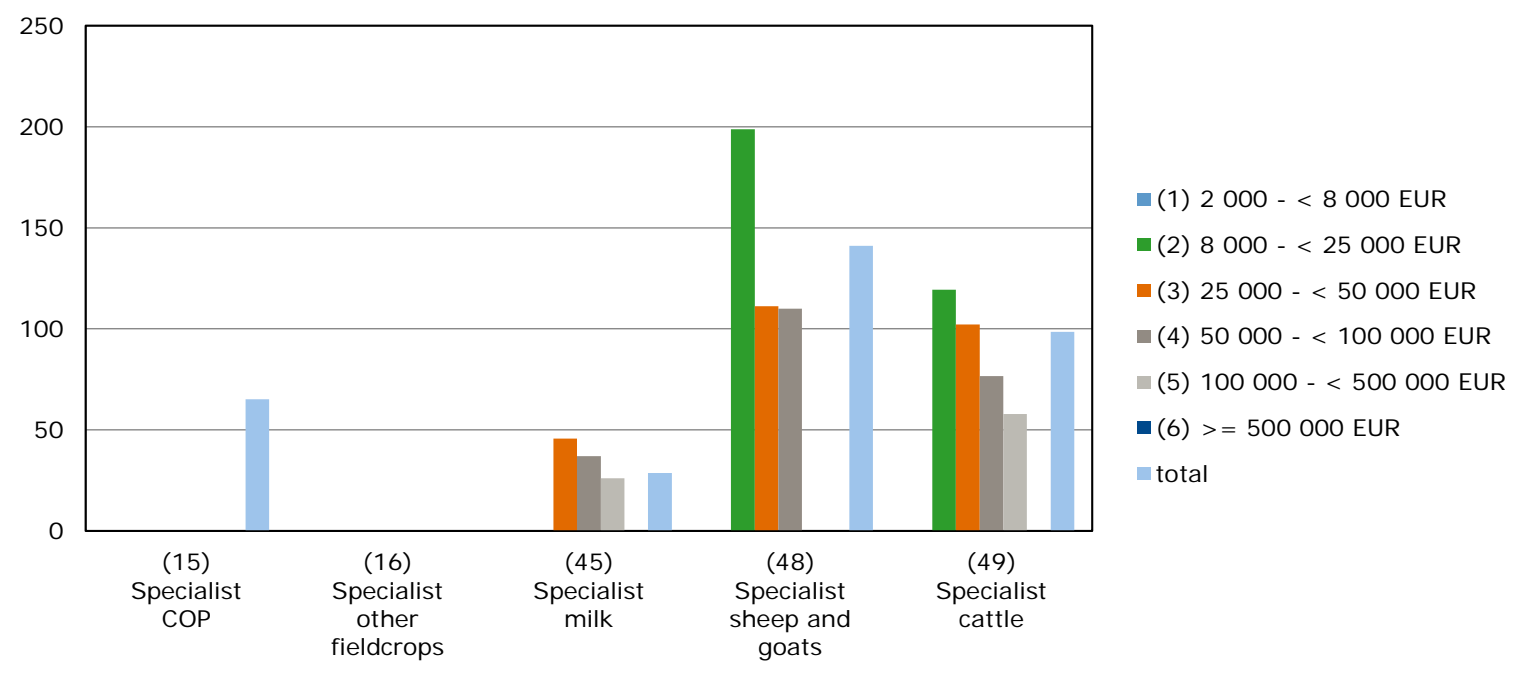

Figure B2.7 Direct payments from the first pillar of the CAP as a percentage of family farm income per family work unit for different farming types in Ireland, 2015

Source and explanation: see Figure B2.1.

Share of P1 payments in family farm income per FWU in Greece (2015)

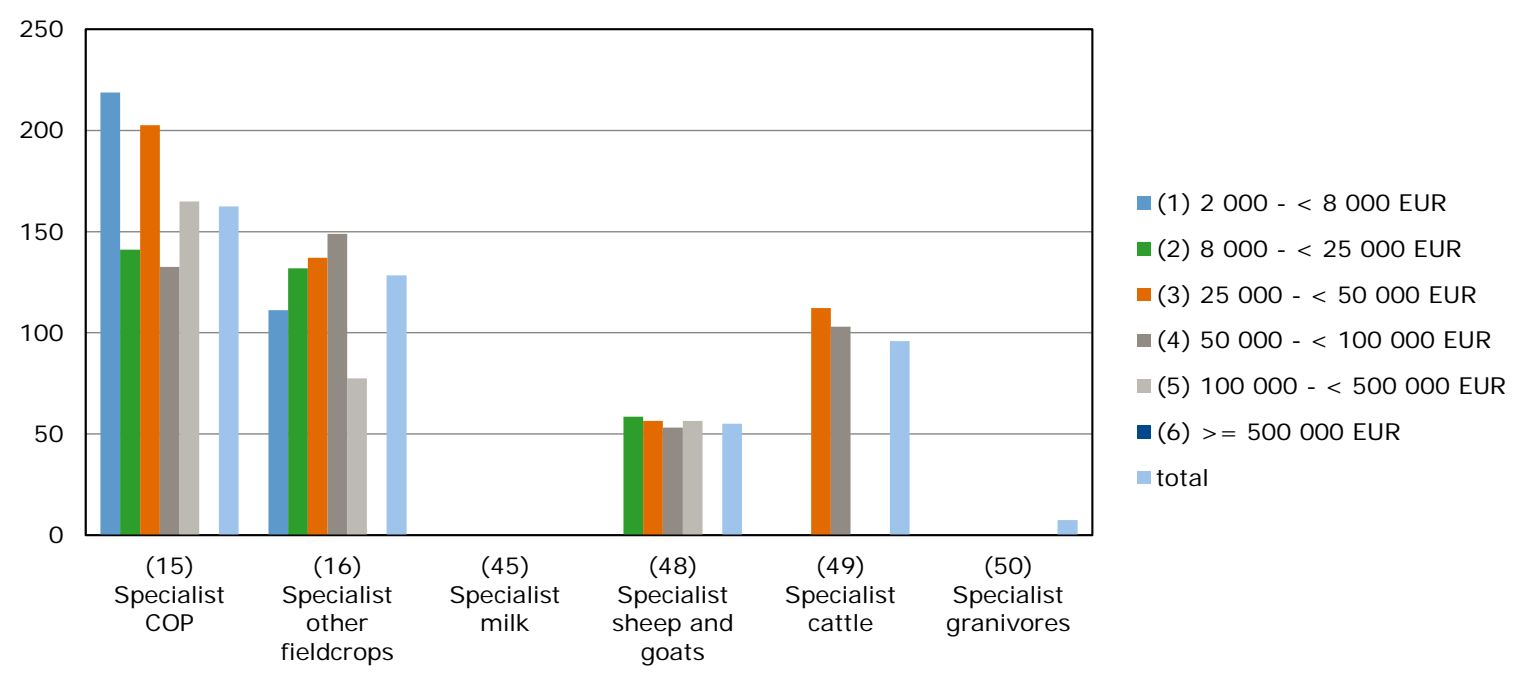

Figure B2.8 Direct payments from the first pillar of the CAP as a percentage of family farm income per family work unit for different farming types in Greece, 2015 Source and explanation: see Figure B2.1. 


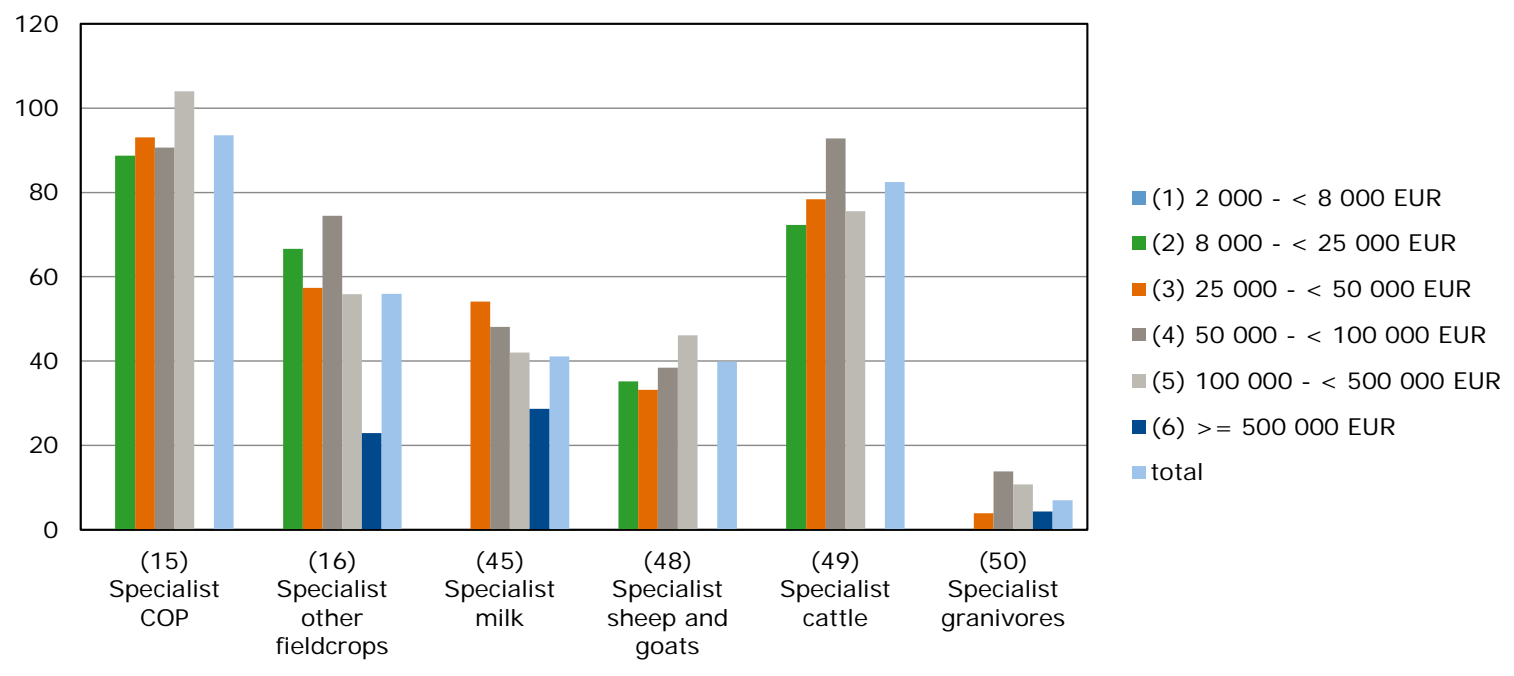

Figure B2.9 Direct payments from the first pillar of the CAP as a percentage of family farm income per family work unit for different farming types in Spain, 2015

Source and explanation: see Figure B2.1.

Share of P1 payments in family farm income per FWU in France (2015)

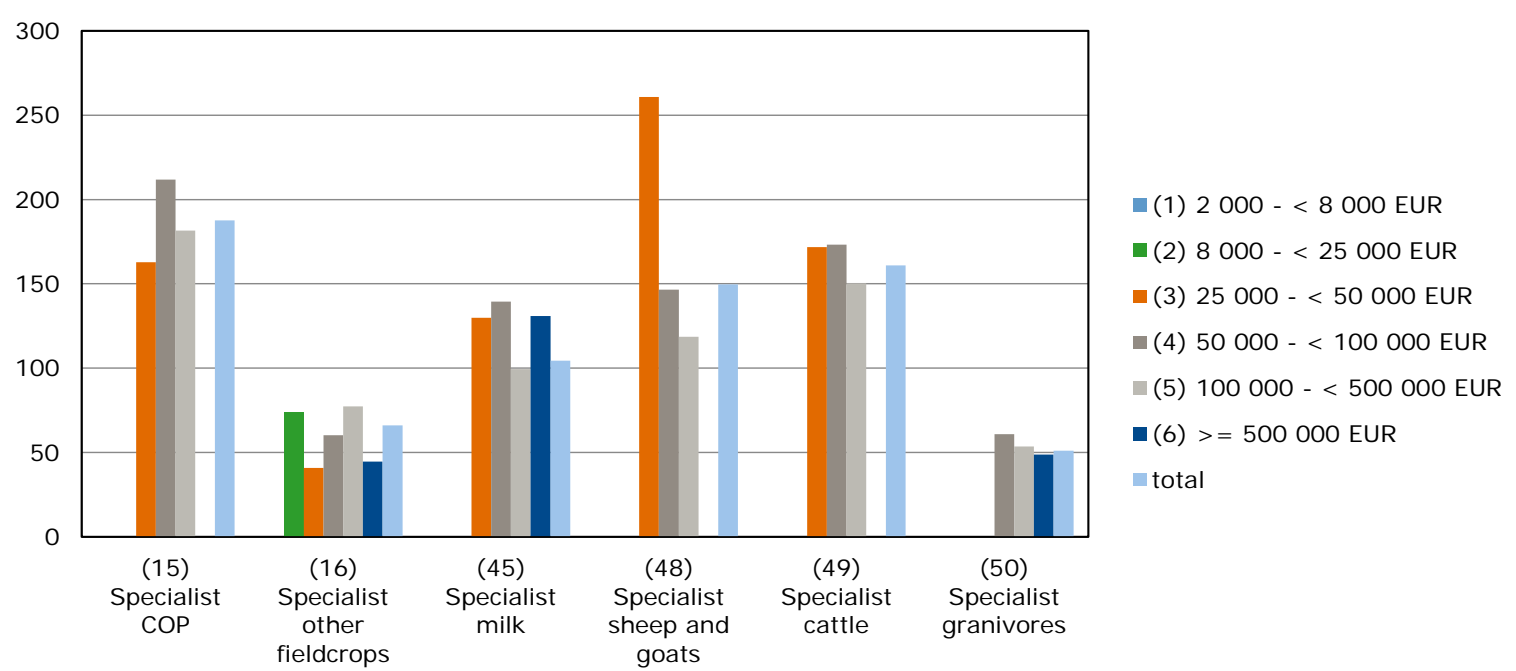

Figure B2.10 Direct payments from the first pillar of the CAP as a percentage of family farm income per family work unit for different farming types in France, 2015

Source and explanation: see Figure B2.1. 


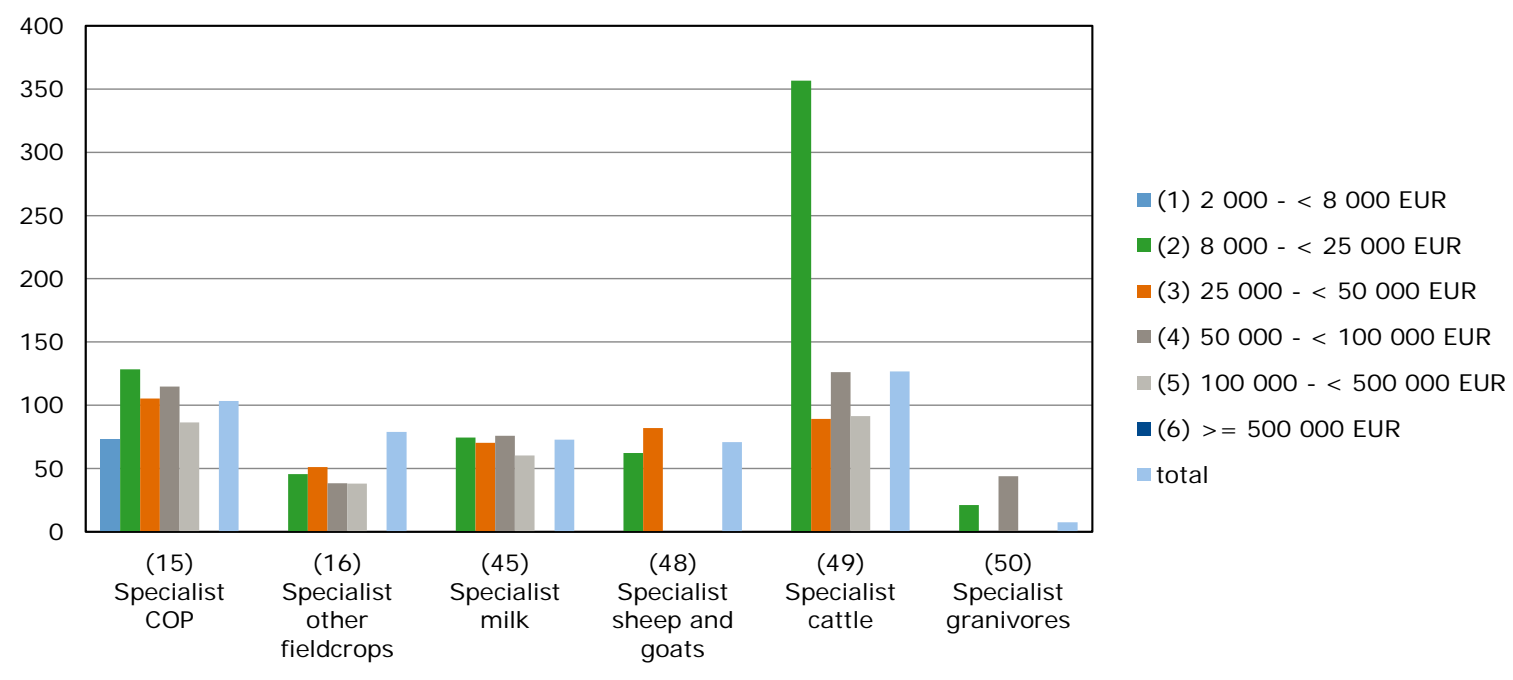

Figure B2.11 Direct payments from the first pillar of the CAP as a percentage of family farm income per family work unit for different farming types in Croatia, 2015

Source and explanation: see Figure B2.1.

Share of P1 payments in family farm income per FWU in Italy (2015)

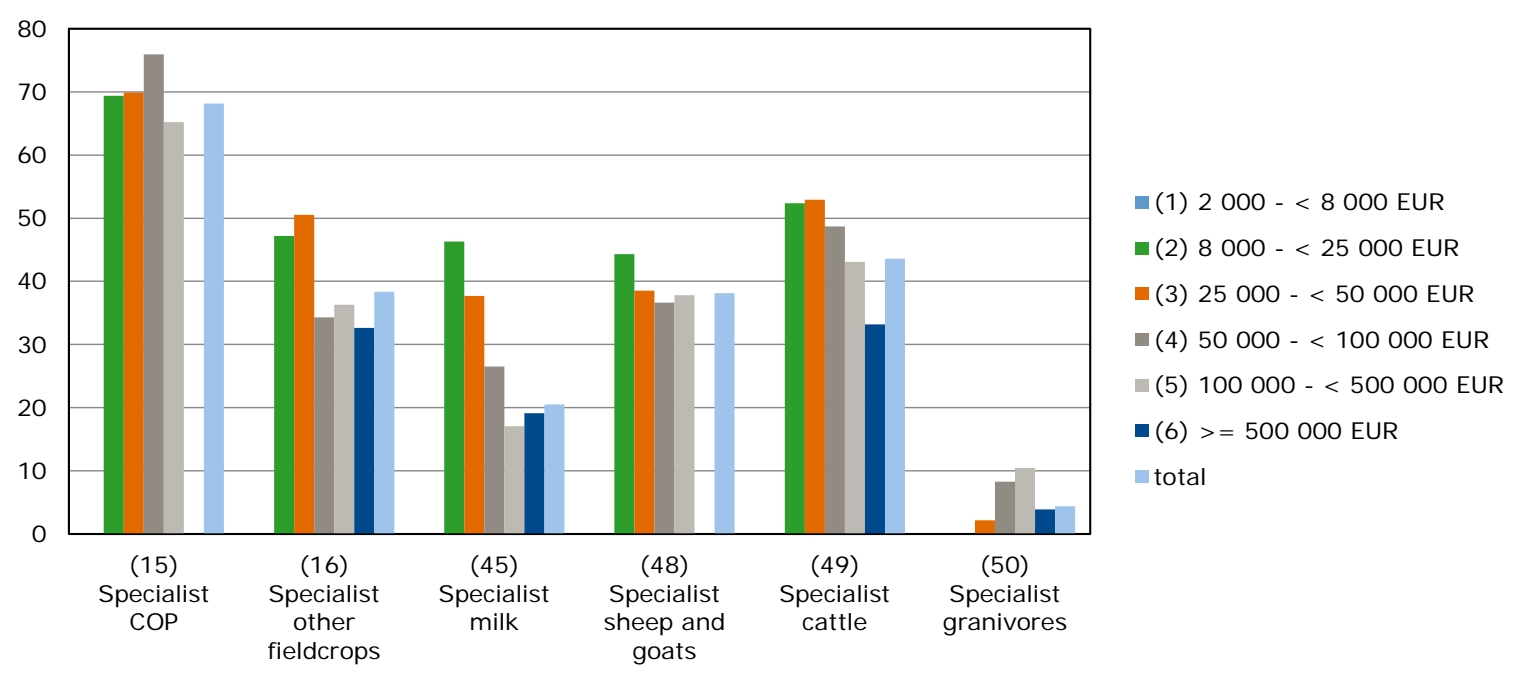

Figure B2.12 Direct payments from the first pillar of the CAP as a percentage of family farm income per family work unit for different farming types in Italy, 2015

Source and explanation: see Figure B2.1. 


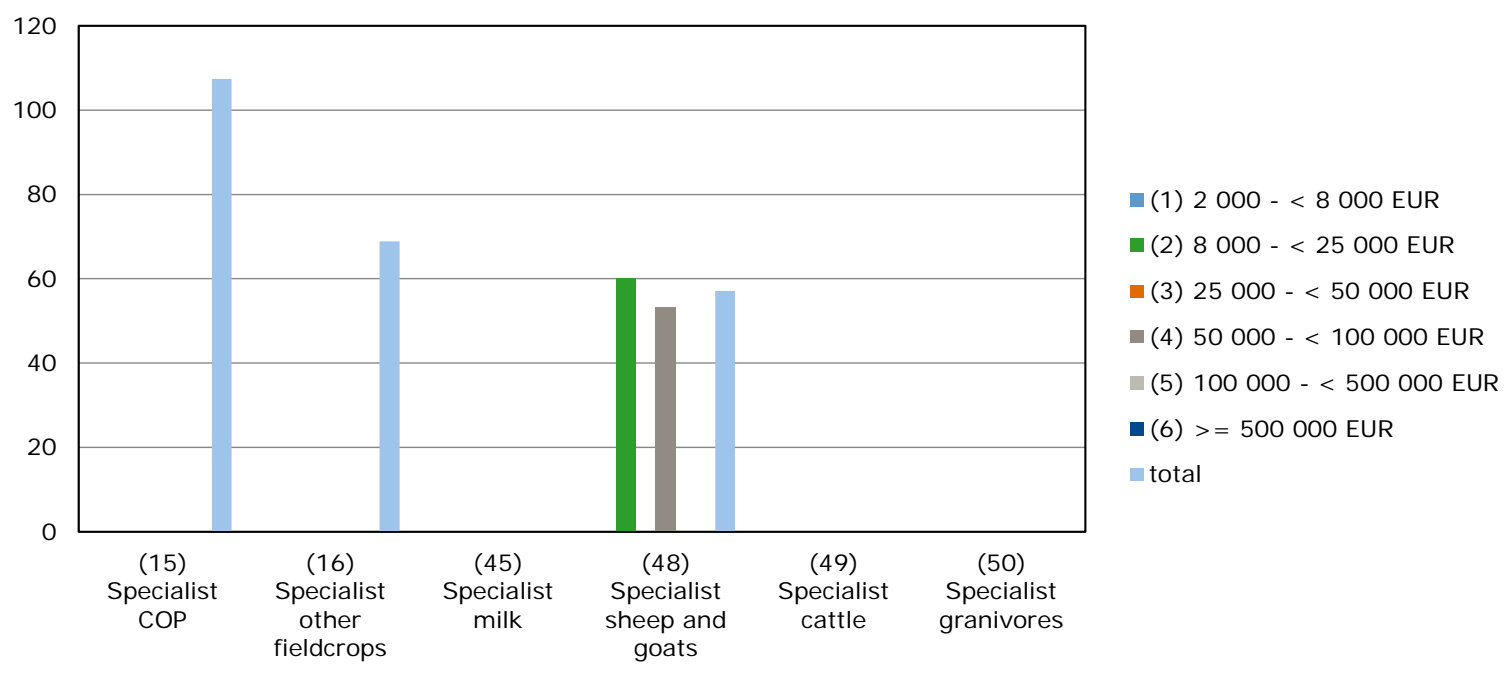

Figure B2.13 Direct payments from the first pillar of the CAP as a percentage of family farm income per family work unit for different farming types in Cyprus, 2015

Source and explanation: see Figure B2.1.

Share of P1 payments in family farm income per FWU in Latvia (2015)

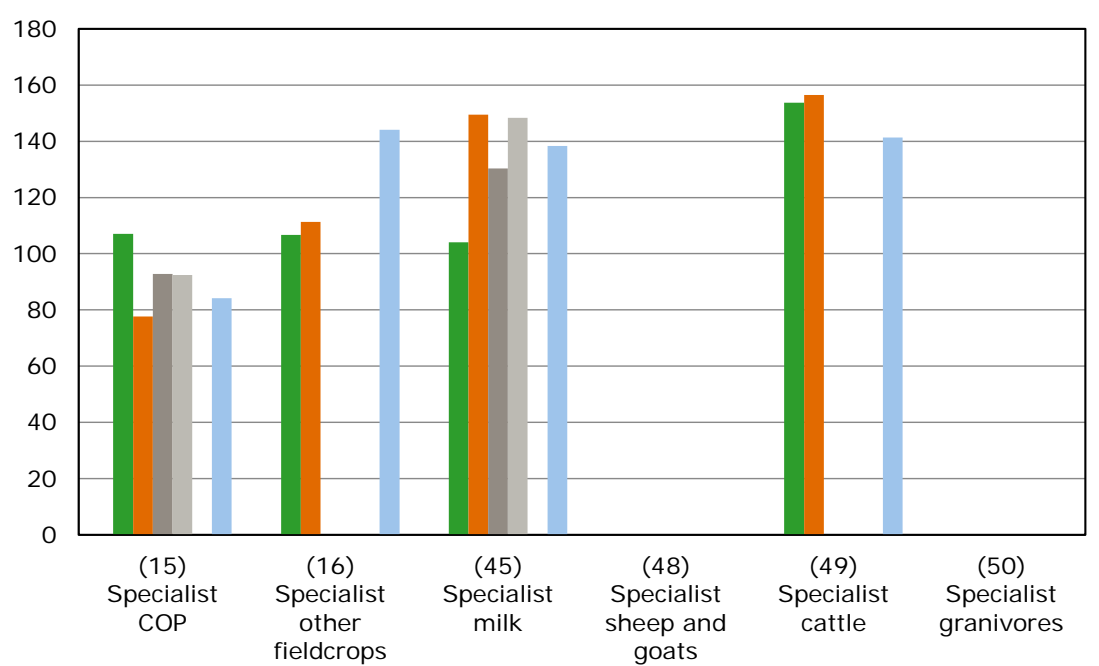

- (1) $2000-<8000$ EUR

- (2) $8000-<25000$ EUR

- (3) $25000-<50000$ EUR

-(4) $50000-<100000$ EUR

$\square(5) 100000-<500000$ EUR

- (6) $>=500000$ EUR

- total

Figure B2.14 Direct payments from the first pillar of the CAP as a percentage of family farm income per family work unit for different farming types in Latvia, 2015

Source and explanation: see Figure B2.1. 
Share of P1 payments in family farm income per FWU in Lithuania (2015)

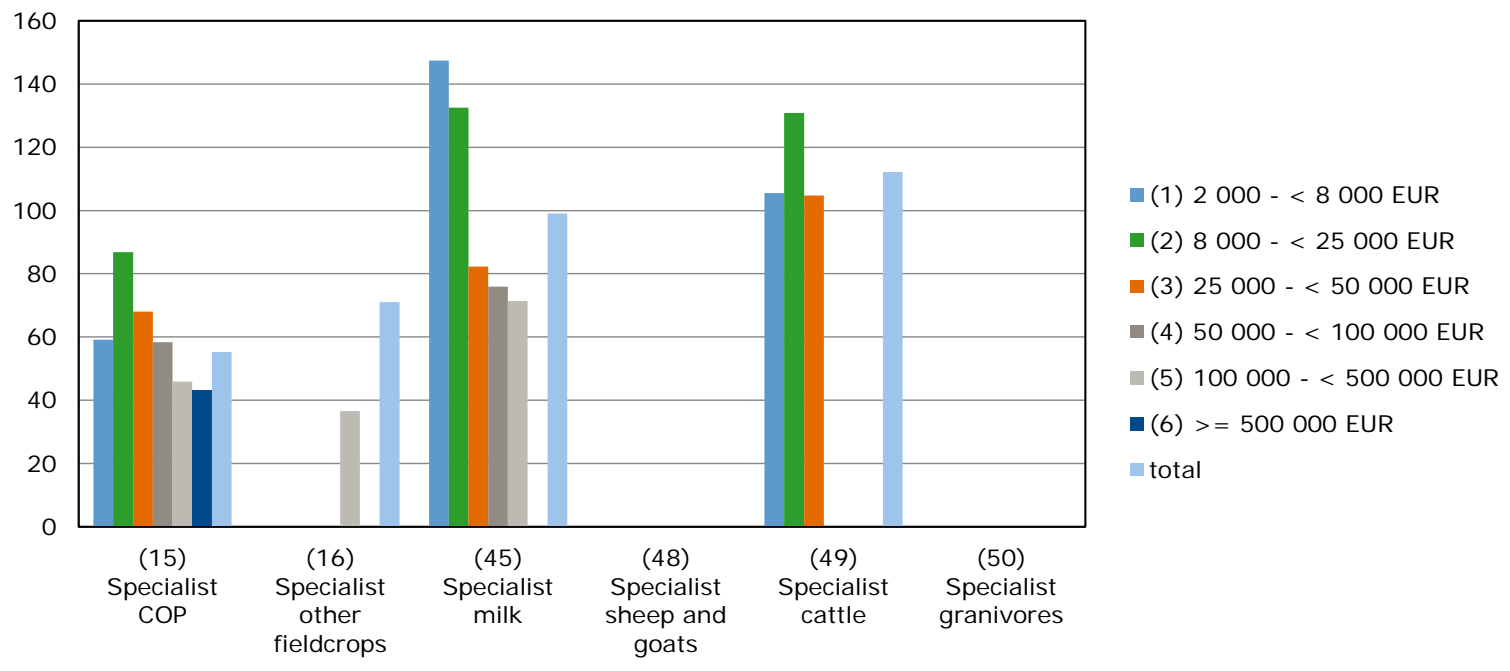

Figure B2.15 Direct payments from the first pillar of the CAP as a percentage of family farm income per family work unit for different farming types in Lithuania, 2015

Source and explanation: see Figure B2.1.

Share of P1 payments in family farm income per FWU in Luxembourg (2015)

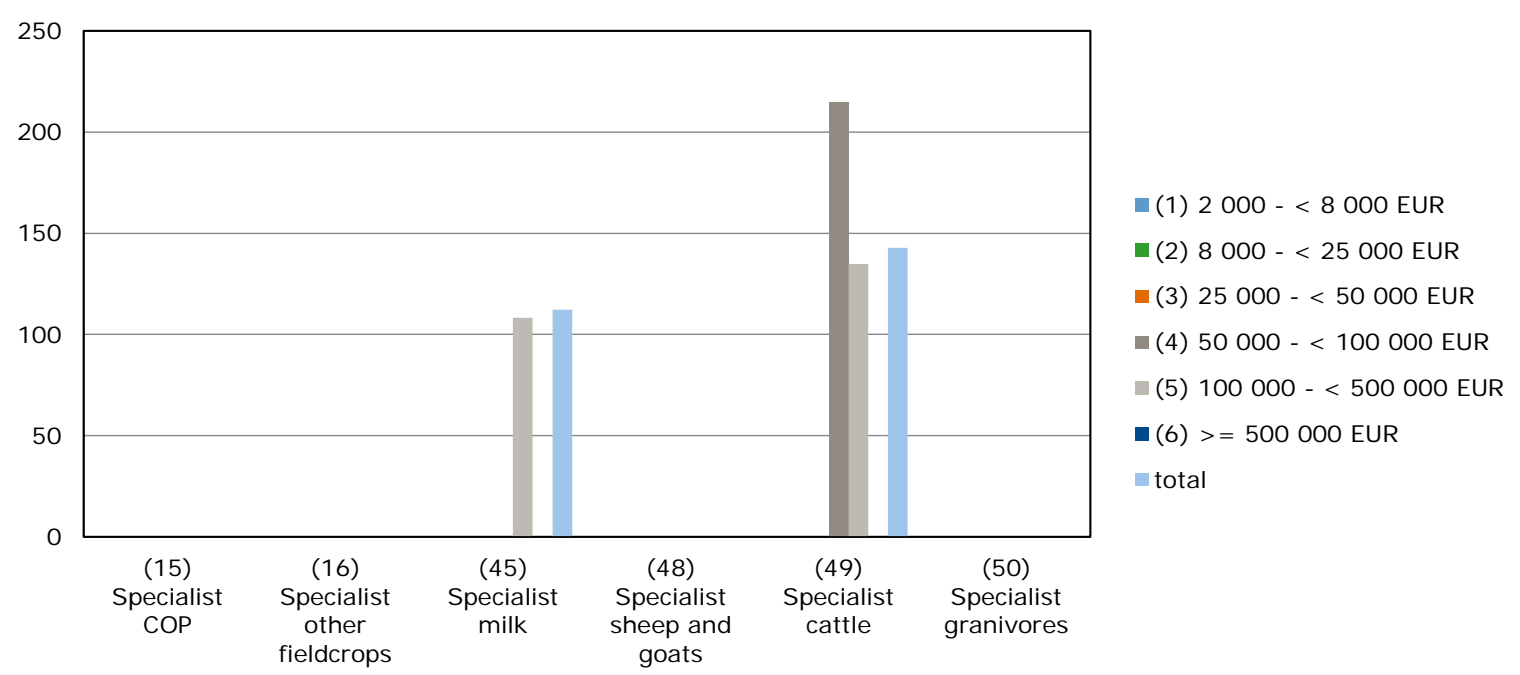

Figure B2.16 Direct payments from the first pillar of the CAP as a percentage of family farm income per family work unit for different farming types in Luxembourg, 2015

Source and explanation: see Figure B2.1. 
Share of P1 payments in family farm income per FWU in Hungary (2015)

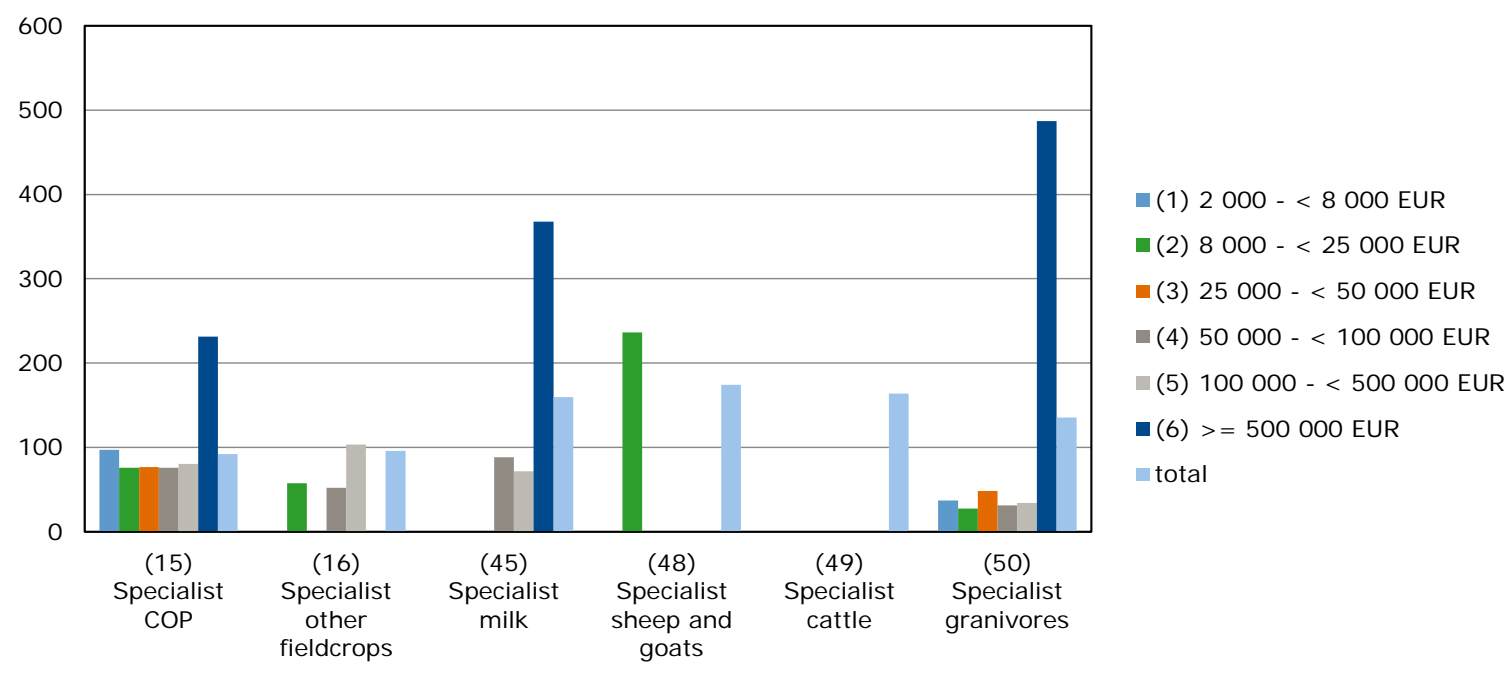

Figure B2.17 Direct payments from the first pillar of the CAP as a percentage of family farm income per family work unit for different farming types in Hungary, 2015

Source and explanation: see Figure B2.1.

Share of P1 payments in family farm income per FWU in Malta (2015)

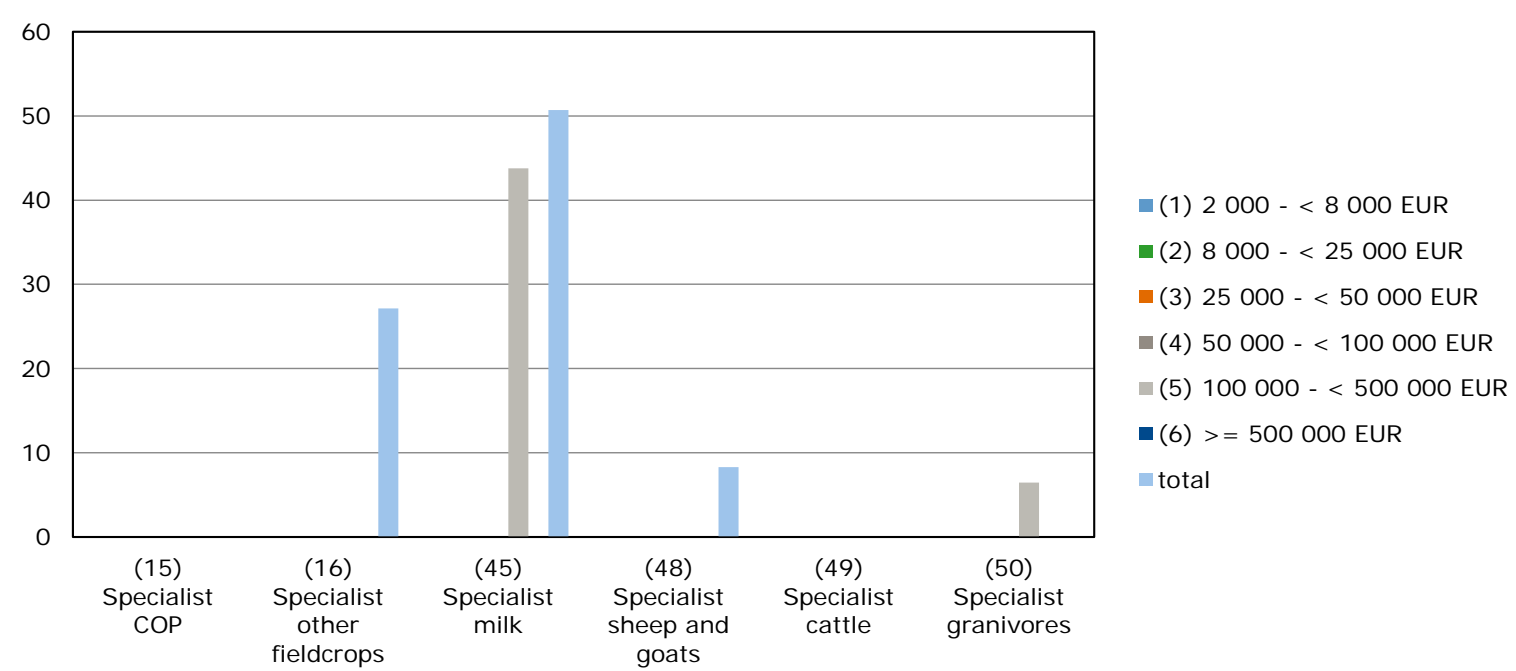

Figure B2.18 Direct payments from the first pillar of the CAP as a percentage of family farm income per family work unit for different farming types in Malta, 2015 Source and explanation: see Figure B2.1. 
Share of P1 payments in family farm income per FWU in Netherlands (2015)

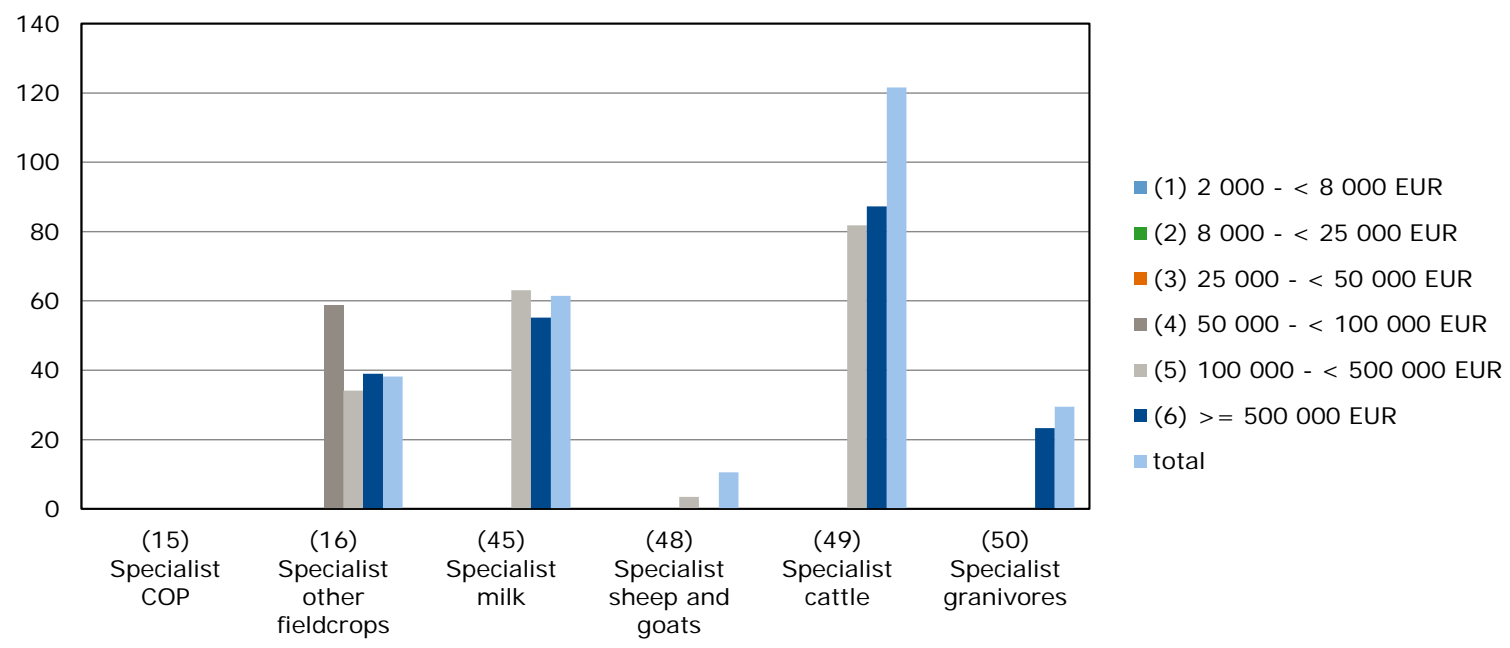

Figure B2.19 Direct payments from the first pillar of the CAP as a percentage of family farm income per family work unit for different farming types in the Netherlands, 2015 Source and explanation: see Figure B2.1.

Share of P1 payments in family farm income per FWU in Austria (2015)

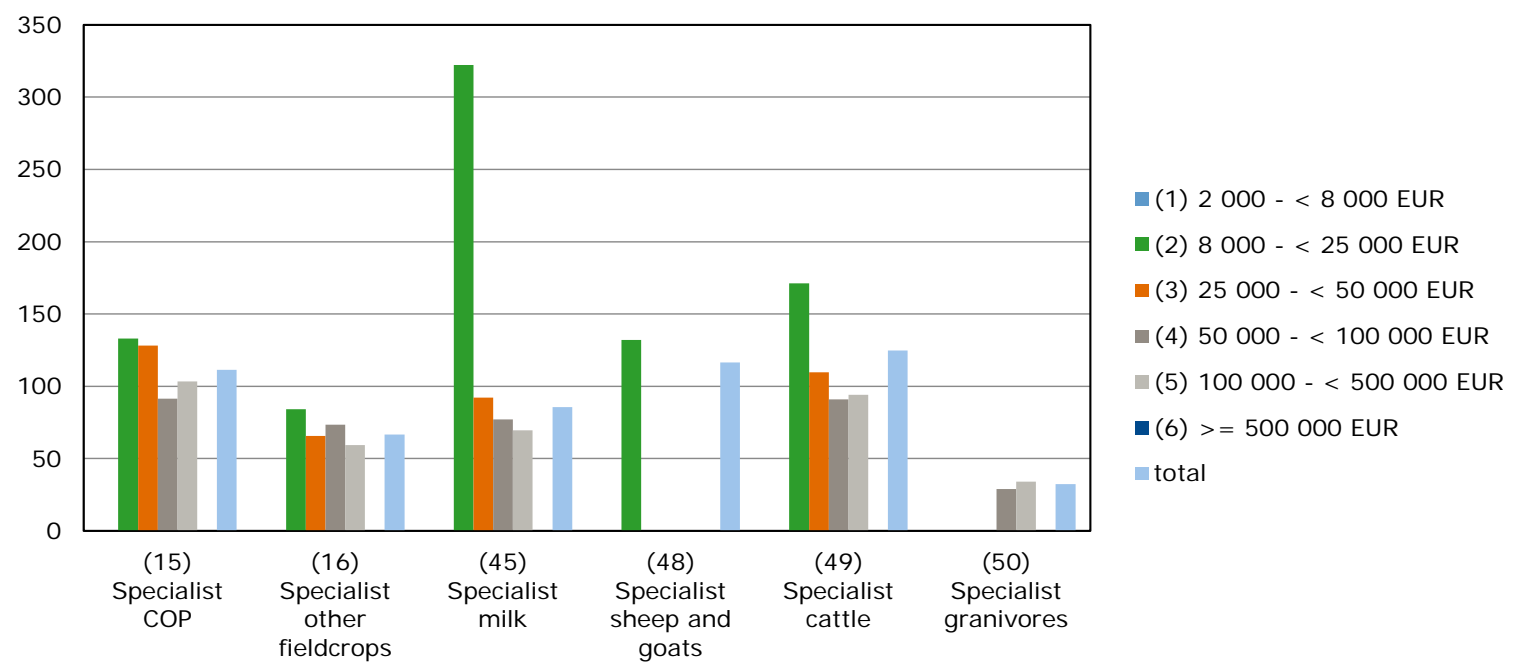

Figure B2.20 Direct payments from the first pillar of the CAP as a percentage of family farm income per family work unit for different farming types in Austria, 2015

Source and explanation: see Figure B2.1. 
Share of P1 payments in family farm income per FWU in Poland (2015)

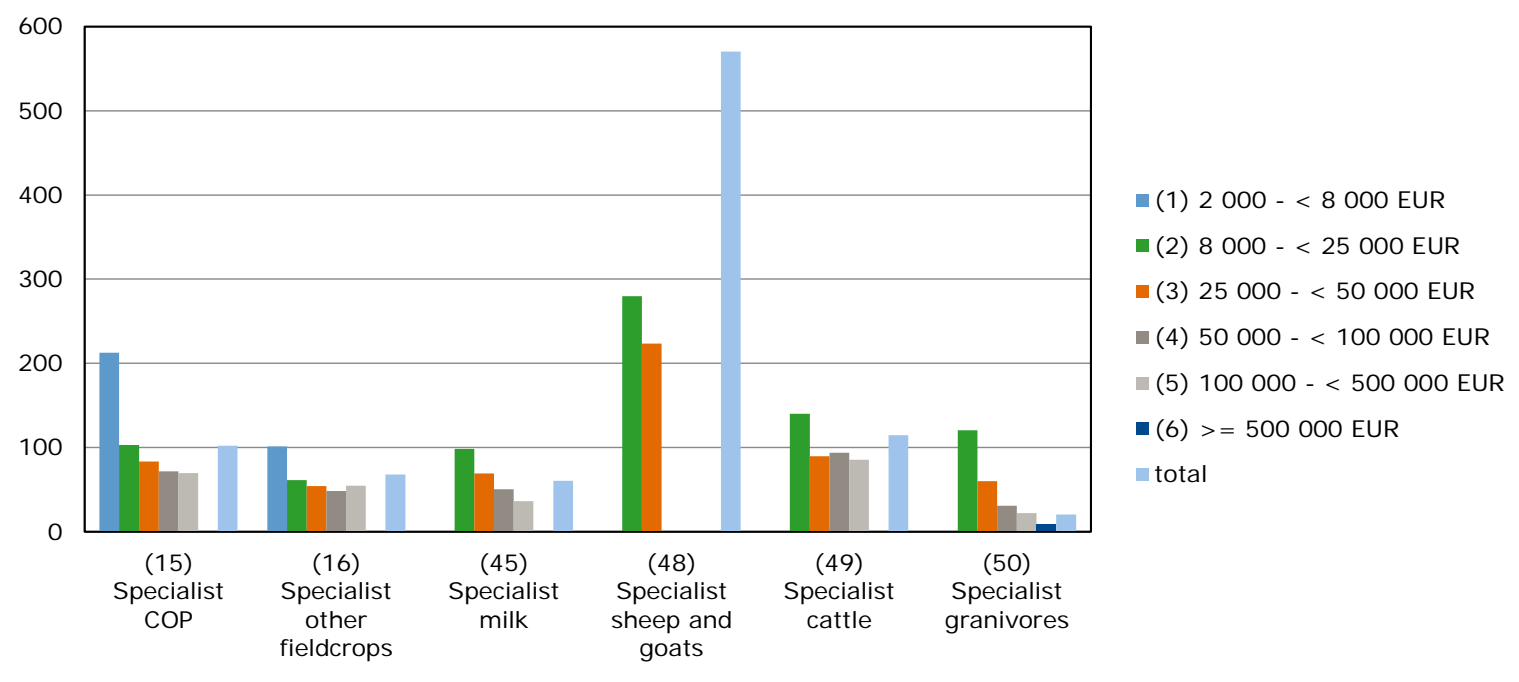

Figure B2.21 Direct payments from the first pillar of the CAP as a percentage of family farm income per family work unit for different farming types in Poland, 2015

Source and explanation: see Figure B2.1.

Share of P1 payments in family farm income per FWU in Portugal (2015)

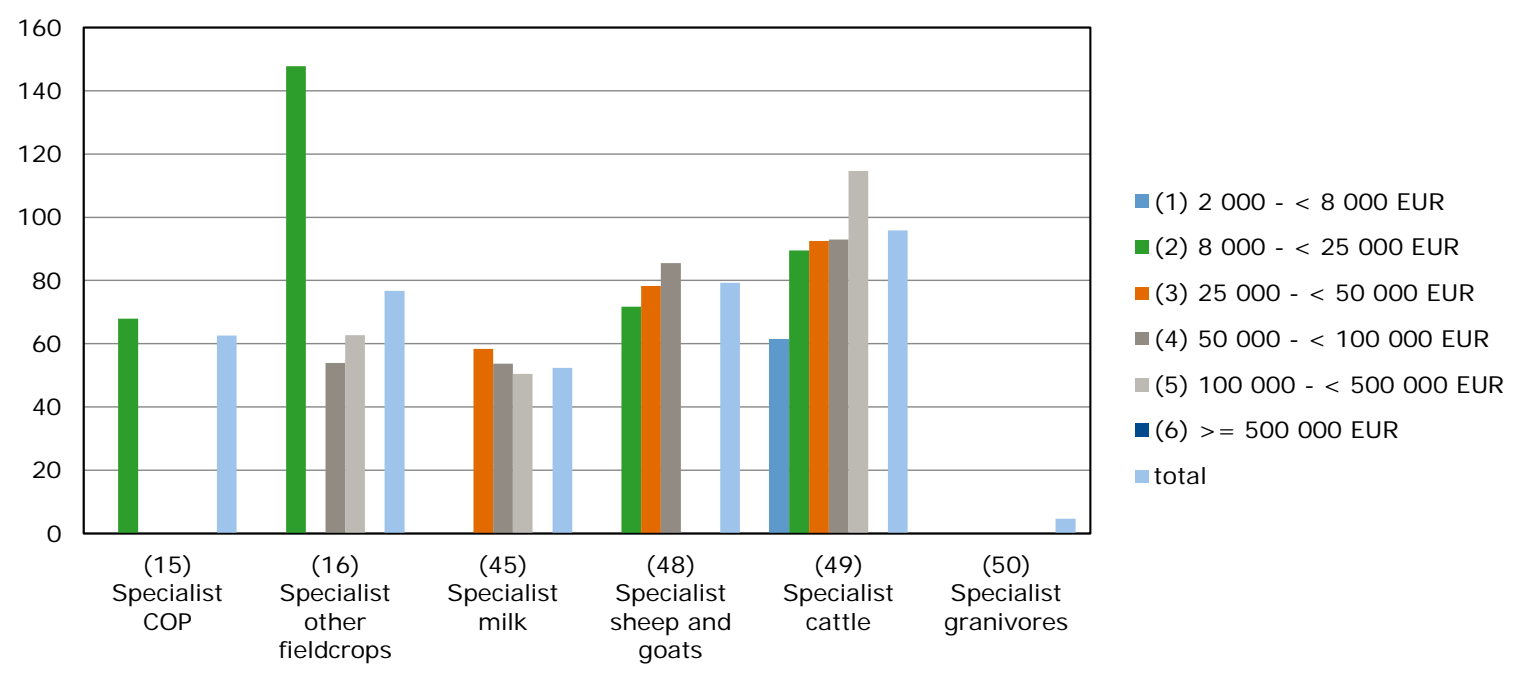

Figure B2.22 Direct payments from the first pillar of the CAP as a percentage of family farm income per family work unit for different farming types in Portugal, 2015 Source and explanation: see Figure B2.1. 
Share of P1 payments in family farm income per FWU in Romania (2015)

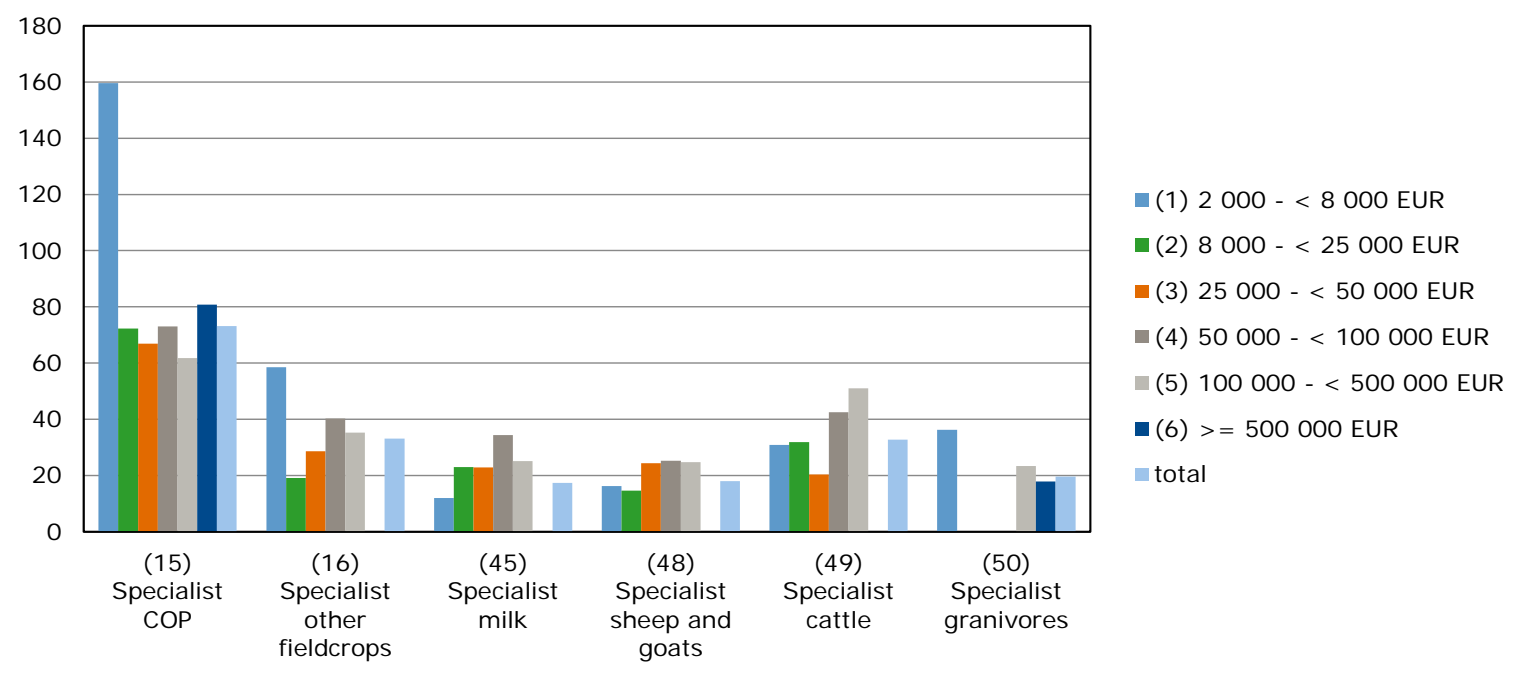

Figure B2.23 Direct payments from the first pillar of the CAP as a percentage of family farm income per family work unit for different farming types in Romania, 2015

Source and explanation: see Figure B2.1.

Share of P1 payments in family farm income per FWU in Slovenia (2015)

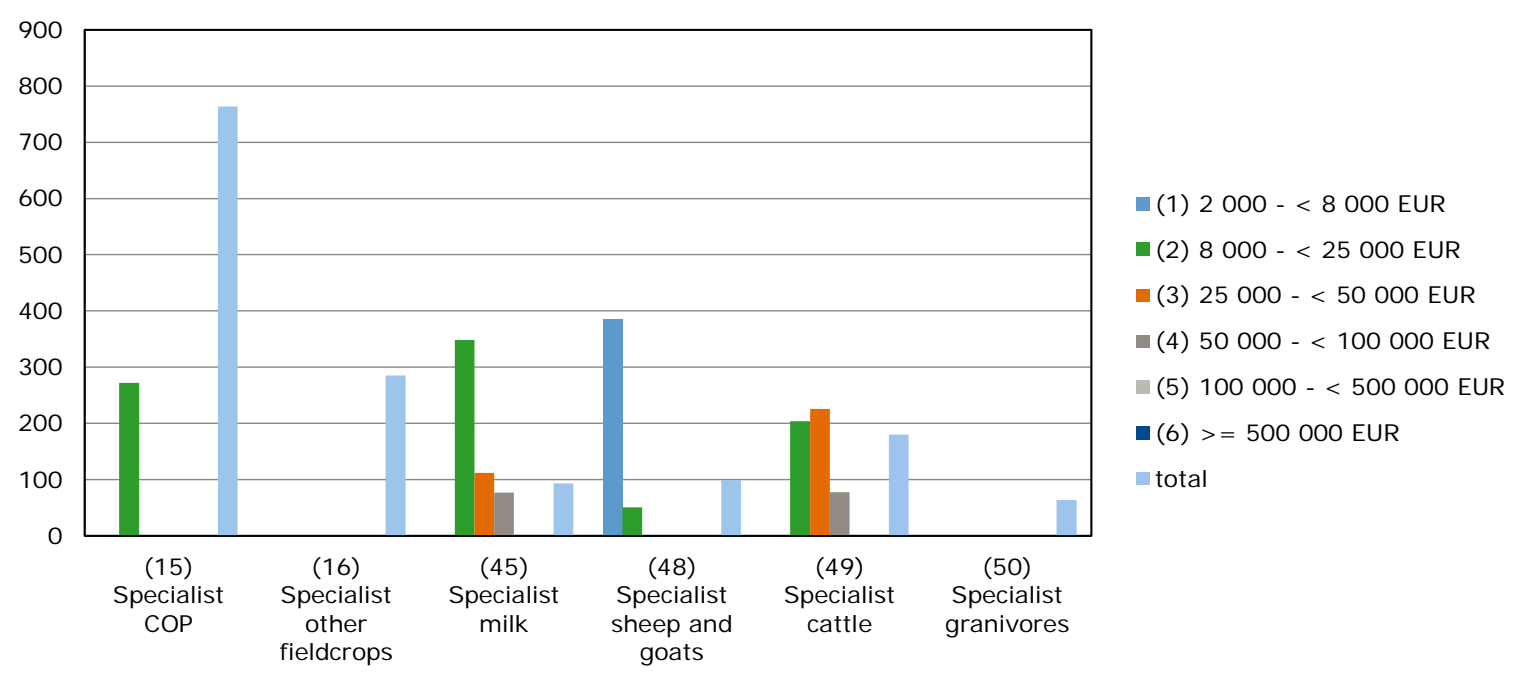

Figure B2.24 Direct payments from the first pillar of the CAP as a percentage of family farm income per family work unit for different farming types in Slovenia, 2015

Source and explanation: see Figure B2.1. 
Share of P1 payments in family farm income per FWU in Slovakia (2015)

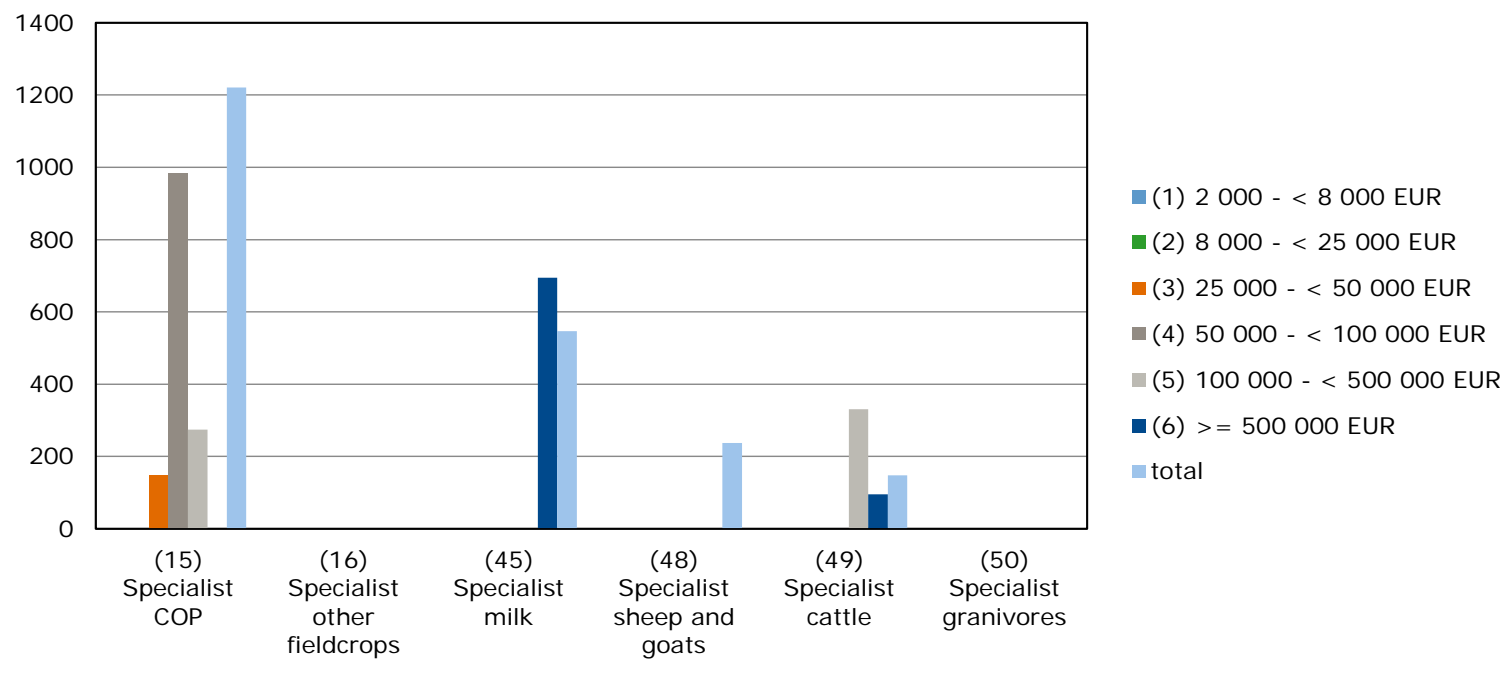

Figure B2.25 Direct payments from the first pillar of the CAP as a percentage of family farm income per family work unit for different farming types in Slovakia, 2015

Source and explanation: see Figure B2.1.

Share of P1 payments in family farm income per FWU in Finland (2015)

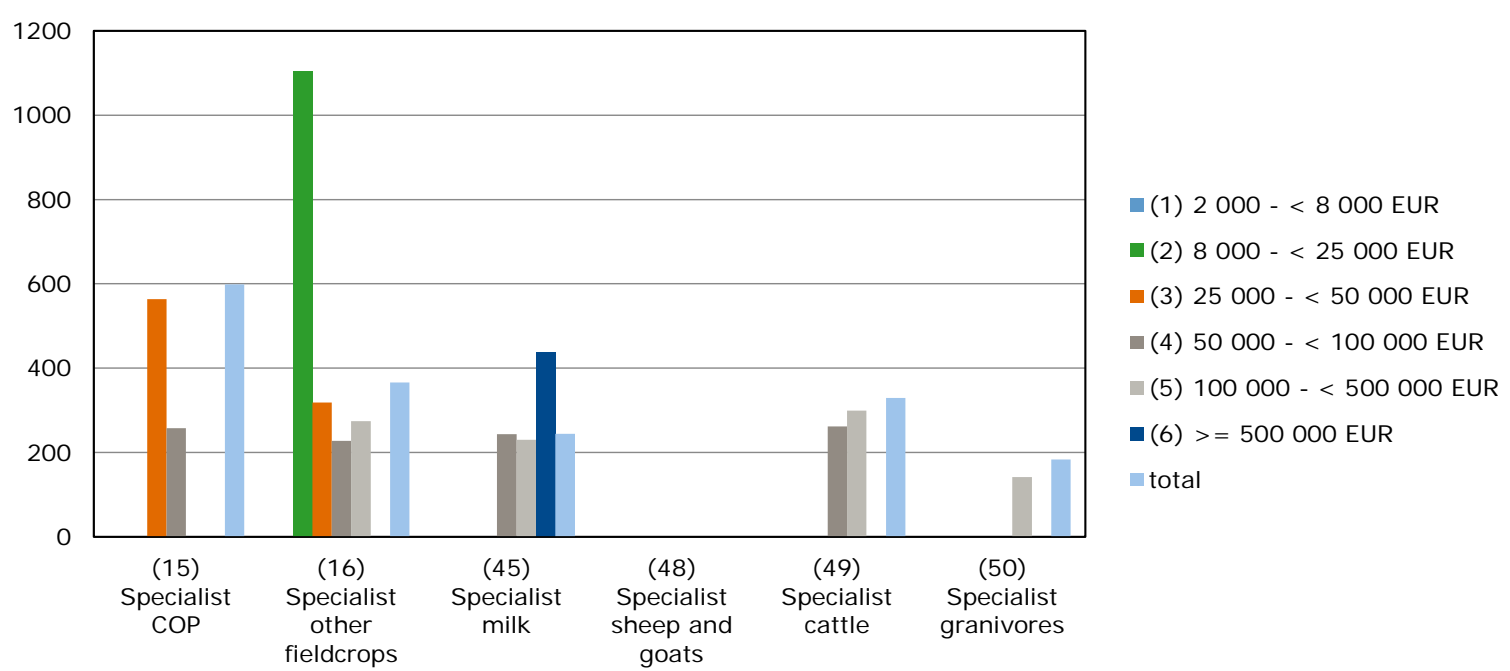

Figure B2.26 Direct payments from the first pillar of the CAP as a percentage of family farm income per family work unit for different farming types in Finland, 2015

Source and explanation: see Figure B2.1. 
Share of P1 payments in family farm income per FWU in Sweden (2015)

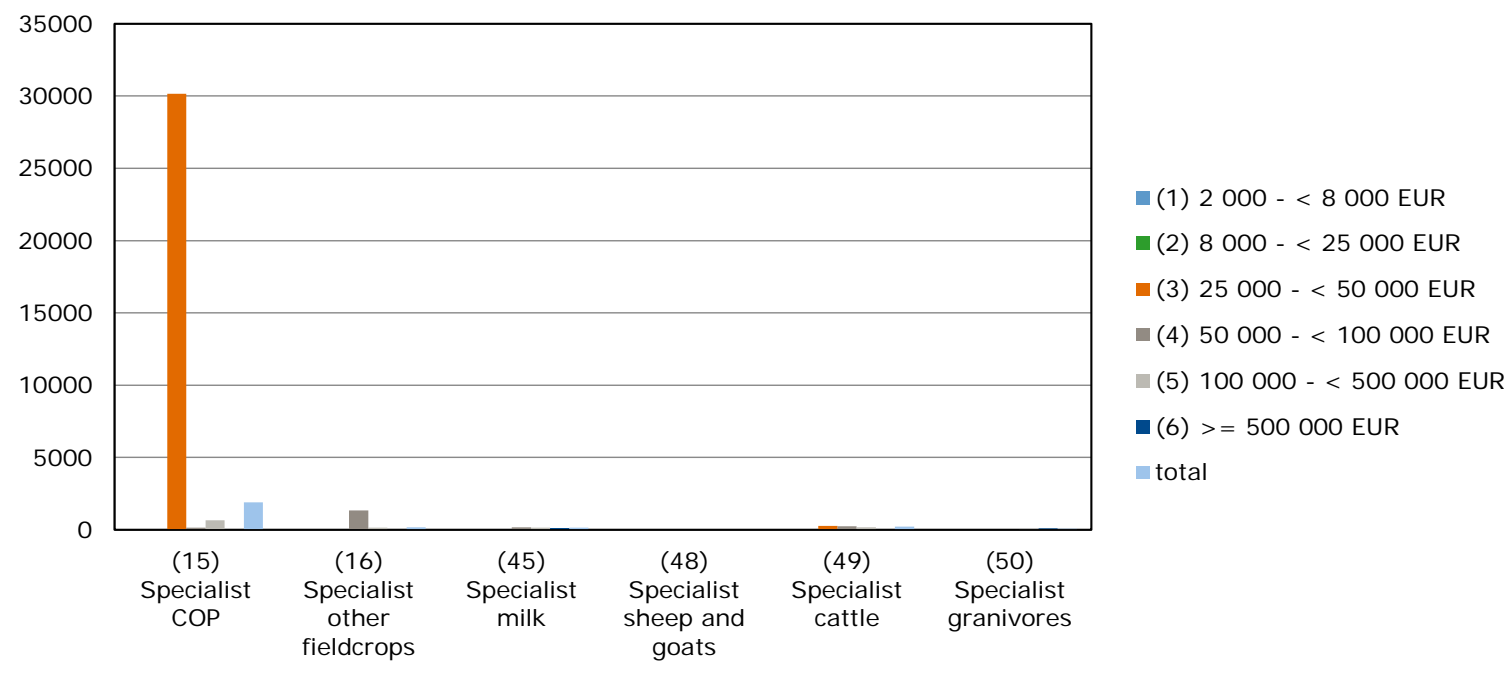

Figure B2.27 Direct payments from the first pillar of the CAP as a percentage of family farm income per family work unit for different farming types in Sweden, 2015

Source and explanation: see Figure B2.1.

Share of P1 payments in family farm income per FWU in United Kingdom (2015)

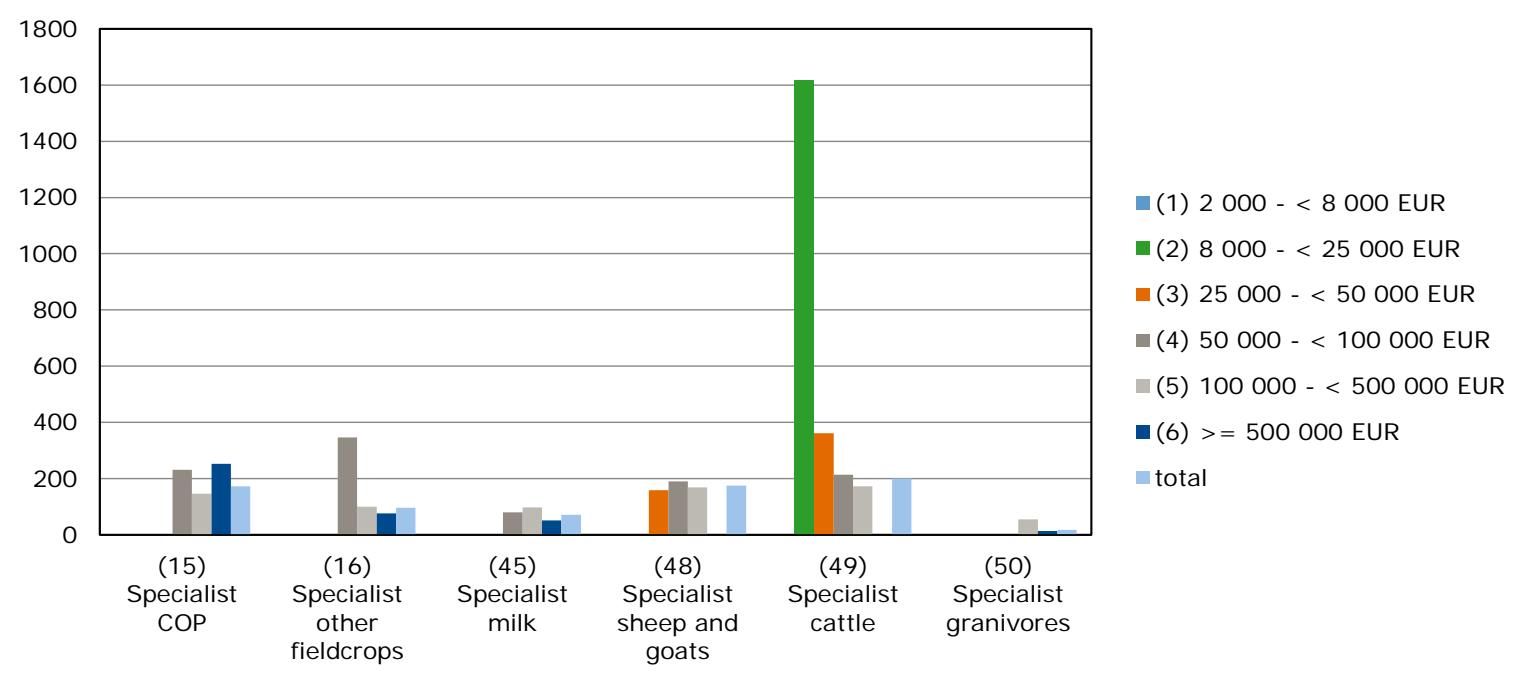

Figure B2.28 Direct payments from the first pillar of the CAP as a percentage of family farm income per family work unit for different farming types in the UK, 2015

Source and explanation: see Figure B2.1. 


\section{Appendix 3 Tables}

Table B3.1 Percentage of farmers that received $20 \%$ of payments in the EU member countries (\% of the total number of farmers)

\begin{tabular}{|c|c|c|c|c|}
\hline & $\begin{array}{l}\text { Percentage based on } \\
\text { actual distribution in } \\
2015\end{array}$ & $\begin{array}{l}\text { Calculated uniform } \\
\text { hectare payment in } \\
2015 \text { (€) }\end{array}$ & $\begin{array}{l}\text { Percentage based on the } \\
\text { fictitious distribution } \\
\text { (calculated with a } \\
\text { uniform hectare } \\
\text { payment) }\end{array}$ & $\begin{array}{l}\text { Difference } \\
\text { between the } 2015 \\
\text { distribution and } \\
\text { the fictitious } \\
\text { distribution }\end{array}$ \\
\hline I reland & 55 & 245 & 52 & 3 \\
\hline The Netherlands & 56 & 416 & 63 & -6 \\
\hline Belgium & 58 & 404 & 57 & 0.3 \\
\hline France & 59 & 271 & 65 & -5 \\
\hline Slovenia & 65 & 282 & 58 & 7 \\
\hline Greece & 66 & 454 & 79 & -13 \\
\hline Poland & 68 & 209 & 64 & 3 \\
\hline Germany & 68 & 306 & 67 & 0.3 \\
\hline Sweden & 74 & 230 & 69 & 5 \\
\hline Denmark & 75 & 346 & 69 & 6 \\
\hline Croatia & 75 & 95 & 79 & -4 \\
\hline Malta & 76 & 460 & 38 & 37 \\
\hline Bulgaria & 84 & 171 & 92 & -8 \\
\hline Portugal & 85 & 158 & 88 & -3 \\
\hline Estonia & 86 & 140 & 85 & 1 \\
\hline Romania & 87 & 139 & 82 & 5 \\
\hline Czech Republic & 89 & 250 & 82 & 7 \\
\hline Slovakia & 93 & 202 & 91 & 2 \\
\hline EU28 & 81 & 243 & 86 & -6 \\
\hline
\end{tabular}

Source: EC (2017b) and Eurostat Farm Structure Survey (FSS); adaptation by Wageningen Economic Research. 
Table B3.2 Number of farmers receiving few and many payments in EU member countries, 2015

\begin{tabular}{|c|c|c|c|c|c|c|c|c|c|c|}
\hline & \multicolumn{9}{|c|}{ Payments received ( $€$ ) } & \multirow{5}{*}{$\begin{array}{l}\text { All bene- } \\
\text { ficiaries }\end{array}$} \\
\hline & \multirow[t]{4}{*}{ none } & \multirow{4}{*}{$\begin{array}{l}\geq 0 \text { and } \\
<0.5 K\end{array}$} & \multirow{4}{*}{$\begin{array}{l}\geq 0.5 \mathrm{~K} \text { and } \\
<150 \mathrm{~K}\end{array}$} & \multicolumn{6}{|c|}{ More than $\geq 150 \mathrm{~K}$} & \\
\hline & & & & $\begin{array}{l}\geq 150 \mathrm{~K} \\
\text { and }\end{array}$ & $\begin{array}{l}\geq 200 \mathrm{~K} \\
\text { and }\end{array}$ & $\begin{array}{l}\geq 250 \mathrm{~K} \\
\text { and }\end{array}$ & $\begin{array}{l}\geq 300 \mathrm{~K} \\
\text { and }\end{array}$ & $\geq 500 \mathrm{~K}$ & $\begin{array}{l}\text { Total no. } \\
\text { of bene- }\end{array}$ & \\
\hline & & & & $<200 K$ & $<250 \mathrm{~K}$ & $<300 \mathrm{~K}$ & $<500 \mathrm{~K}$ & & ficiaries & \\
\hline & & & & & & & & & $\geq 150 \mathrm{~K}$ & \\
\hline $\mathrm{BE}$ & 5 & 651 & 33,583 & 16 & 6 & & 1 & - & 23 & 34,262 \\
\hline BG & 1 & 8,203 & 58,343 & 343 & 182 & 91 & 145 & 51 & 812 & 67,359 \\
\hline$C Z$ & - & 2,973 & 24,508 & 43 & 243 & 190 & 413 & 274 & 1,459 & 28,940 \\
\hline DK & 89 & 111 & 40,114 & 328 & 181 & 63 & 70 & 8 & 650 & 40,964 \\
\hline $\mathrm{DE}$ & 34 & 14,286 & 303,684 & 949 & 710 & 471 & 806 & 382 & 3,318 & 321,322 \\
\hline $\mathrm{EE}$ & - & 4,558 & 12,548 & 42 & 16 & 13 & 13 & 1 & 85 & 17,191 \\
\hline IE & 16 & 5.166 & 122,502 & 30 & 14 & - & - & - & 44 & 127,728 \\
\hline GR & 56 & 134,021 & 528,748 & 15 & 1 & - & - & - & 16 & 662,841 \\
\hline ES & 43 & 194,210 & 606,463 & 714 & 324 & 171 & 220 & 89 & 1,518 & 802,234 \\
\hline FR & 136 & 16,708 & 322,958 & 74 & 87 & 35 & 48 & 72 & 596 & 340,398 \\
\hline HR & 206 & 41,437 & 54,073 & 9 & 9 & 9 & 6 & 11 & 44 & 95,925 \\
\hline IT & 571 & 202,078 & 663,406 & 653 & 303 & 156 & 204 & 80 & 1,396 & 867,451 \\
\hline $\mathrm{CY}$ & 33 & 18,426 & 14,504 & 2 & - & - & - & - & 2 & 32,965 \\
\hline LV & - & 11,025 & 49,979 & 38 & 24 & 7 & 7 & 4 & 80 & 61,084 \\
\hline LT & 537 & 43,669 & 93,327 & 46 & 39 & 14 & 22 & 5 & 126 & 137,659 \\
\hline LU & - & 81 & 1,744 & 2 & - & - & - & - & 2 & 1,827 \\
\hline $\mathrm{HU}$ & 203 & 8,457 & 166,107 & 286 & 197 & 192 & 284 & 114 & 1,073 & 175,840 \\
\hline MT & - & 3,837 & 1,492 & - & - & - & - & - & 0 & 5,329 \\
\hline $\mathrm{NL}$ & - & 170 & 45,546 & 78 & 15 & 7 & 8 & 2 & 110 & 45,851 \\
\hline AT & - & 11,885 & 98,286 & 17 & 5 & 8 & 3 & 3 & 36 & 110,207 \\
\hline $\mathrm{PL}$ & 16 & 386,948 & 962,429 & 200 & 102 & 76 & 65 & 21 & 464 & $1,349,857$ \\
\hline PT & 56 & 91,717 & 82,942 & 162 & 60 & 30 & 27 & 9 & 309 & 175,024 \\
\hline RO & 73 & 567,837 & 310,362 & 163 & 185 & 122 & 83 & 116 & 953 & 879,225 \\
\hline SI & - & 14,549 & 43,129 & 5 & - & 1 & 5 & 5 & 16 & 57,694 \\
\hline SK & - & 4,163 & 13,282 & 180 & 142 & 119 & 243 & 140 & 824 & 18,269 \\
\hline $\mathrm{FI}$ & - & 900 & 51,842 & 36 & 10 & 10 & 2 & - & 58 & 52,800 \\
\hline SE & 1 & 533 & 59,392 & 125 & 29 & 22 & 14 & 4 & 194 & 60,120 \\
\hline UK & 66 & 1,164 & 142,433 & 802 & 357 & 176 & 19 & 62 & 1,581 & 145,244 \\
\hline EU28 & 2307 & $1,789,788$ & $4,907,726$ & 6,158 & 3,241 & 1,983 & 2,954 & 1,453 & 15,789 & $6,715,610$ \\
\hline
\end{tabular}


Table B3.3 Percentage of farmers for each category of payments received out of the total number of farmers in EU member countries, 2015 (\% of the total number of farmers)

\begin{tabular}{|c|c|c|c|c|c|c|c|c|c|c|c|c|c|c|}
\hline & $\mathrm{Pay}$ & ints rece & eived ( & & & & & & & & & & & \\
\hline & $\begin{array}{l}\text { n̊ } \\
\text { ò }\end{array}$ & 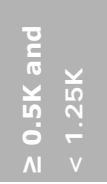 & 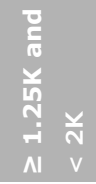 & 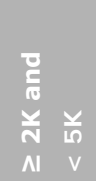 & 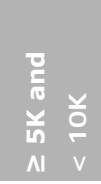 & 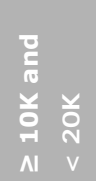 & 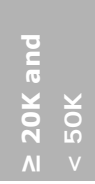 & 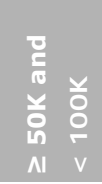 & 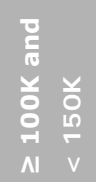 & 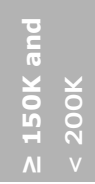 & 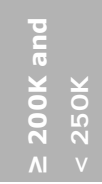 & 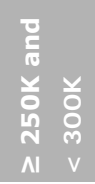 & 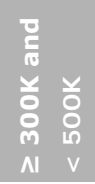 & 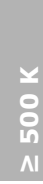 \\
\hline $\mathrm{BE}$ & 2 & 9 & 7 & 16 & 16 & 23 & 23 & 4 & 0 & 0 & 0 & 0 & 0 & 0 \\
\hline BG & 12 & 26 & 12 & 20 & 13 & 8 & 5 & 2 & 1 & 1 & 0 & 0 & 0 & 0 \\
\hline$C Z$ & 10 & 17 & 11 & 21 & 12 & 10 & 8 & 3 & 2 & 1 & 1 & 1 & 1 & 1 \\
\hline DK & 0 & 15 & 11 & 21 & 13 & 12 & 14 & 9 & 2 & 1 & 0 & 0 & 0 & 0 \\
\hline $\mathrm{DE}$ & 4 & 12 & 9 & 19 & 18 & 19 & 15 & 3 & 1 & 0 & 0 & 0 & 0 & 0 \\
\hline $\mathrm{EE}$ & 27 & 28 & 12 & 14 & 7 & 5 & 5 & 2 & 1 & 0 & 0 & 0 & 0 & 0 \\
\hline IE & 4 & 7 & 7 & 26 & 25 & 19 & 10 & 1 & 0 & 0 & 0 & 0 & 0 & 0 \\
\hline $\mathrm{GR}$ & 20 & 28 & 13 & 21 & 10 & 5 & 2 & 0 & 0 & 0 & 0 & 0 & 0 & 0 \\
\hline ES & 24 & 22 & 11 & 18 & 10 & 8 & 6 & 1 & 0 & 0 & 0 & 0 & 0 & 0 \\
\hline $\mathrm{FR}$ & 5 & 9 & 5 & 11 & 11 & 19 & 32 & 8 & 1 & 0 & 0 & 0 & 0 & 0 \\
\hline HR & 43 & 31 & 9 & 10 & 4 & 2 & 1 & 0 & 0 & 0 & 0 & 0 & 0 & 0 \\
\hline IT & 23 & 31 & 12 & 17 & 8 & 5 & 3 & 1 & 0 & 0 & 0 & 0 & 0 & 0 \\
\hline $\mathrm{CY}$ & 56 & 23 & 7 & 8 & 3 & 2 & 1 & 0 & 0 & 0 & 0 & 0 & 0 & 0 \\
\hline LV & 18 & 53 & 9 & 11 & 4 & 3 & 2 & 0 & 0 & 0 & 0 & 0 & 0 & 0 \\
\hline LT & 32 & 30 & 12 & 14 & 6 & 4 & 2 & 0 & 0 & 0 & 0 & 0 & 0 & 0 \\
\hline LU & 4 & 6 & 5 & 12 & 12 & 22 & 34 & 5 & 0 & 0 & 0 & 0 & 0 & 0 \\
\hline $\mathrm{HU}$ & 5 & 42 & 13 & 20 & 9 & 5 & 4 & 2 & 0 & 0 & 0 & 0 & 0 & 0 \\
\hline MT & 72 & 18 & 4 & 3 & 1 & 1 & 1 & 0 & 0 & 0 & 0 & 0 & 0 & 0 \\
\hline $\mathrm{NL}$ & 0 & 8 & 7 & 17 & 15 & 24 & 24 & 3 & 0 & 0 & 0 & 0 & 0 & 0 \\
\hline AT & 11 & 14 & 10 & 26 & 21 & 14 & 5 & 0 & 0 & 0 & 0 & 0 & 0 & 0 \\
\hline PL & 29 & 28 & 13 & 19 & 8 & 3 & 1 & 0 & 0 & 0 & 0 & 0 & 0 & 0 \\
\hline PT & 52 & 18 & 7 & 10 & 5 & 4 & 2 & 1 & 0 & 0 & 0 & 0 & 0 & 0 \\
\hline RO & 65 & 22 & 5 & 4 & 2 & 1 & 1 & 0 & 0 & 0 & 0 & 0 & 0 & 0 \\
\hline SI & 25 & 29 & 15 & 20 & 7 & 3 & 1 & 0 & 0 & 0 & 0 & 0 & 0 & 0 \\
\hline SK & 23 & 26 & 11 & 16 & 7 & 5 & 5 & 3 & 1 & 1 & 1 & 1 & 1 & 1 \\
\hline $\mathrm{FI}$ & 2 & 10 & 10 & 26 & 22 & 18 & 10 & 2 & 0 & 0 & 0 & 0 & 0 & 0 \\
\hline SE & 1 & 23 & 14 & 22 & 13 & 11 & 11 & 4 & 1 & 0 & 0 & 0 & 0 & 0 \\
\hline UK & 1 & 3 & 9 & 20 & 17 & 19 & 21 & 7 & 2 & 1 & 0 & 0 & 0 & 0 \\
\hline EU28 & 27 & 24 & 10 & 16 & 9 & 7 & 5 & 1 & 0 & 0 & 0 & 0 & 0 & 0 \\
\hline
\end{tabular}

Source: EC (2017b); adaptation by Wageningen Economic Research. 
Table B3.4 Percentage of each category of payments received out of the total payments in the EU member countries, 2015 (\% of total payments)

\begin{tabular}{|c|c|c|c|c|c|c|c|c|c|c|c|c|c|c|}
\hline & Paym & its rec & eived $(t$ & & & & & & & & & & & \\
\hline & ڤ̊ & 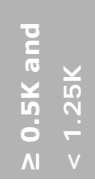 & 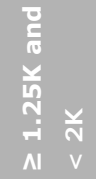 & 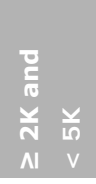 & 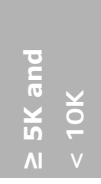 & 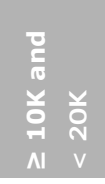 & 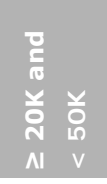 & 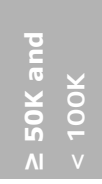 & 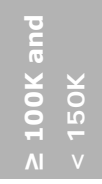 & 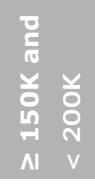 & 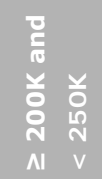 & 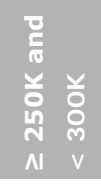 & 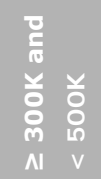 & 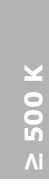 \\
\hline $\mathrm{BE}$ & 0.0 & 0 & 1 & 4 & 8 & 22 & 45 & 17 & 2 & 1 & 0 & 0 & 0 & 0 \\
\hline$B G$ & 0.3 & 2 & 2 & 6 & 9 & 10 & 13 & 15 & 11 & 8 & 6 & 4 & 7 & 7 \\
\hline$C Z$ & 0.1 & 1 & 1 & 2 & 3 & 5 & 9 & 9 & 7 & 7 & 7 & 6 & 19 & 25 \\
\hline DK & -0.1 & 1 & 1 & 3 & 5 & 8 & 22 & 29 & 14 & 7 & 5 & 2 & 3 & 1 \\
\hline $\mathrm{DE}$ & 0.1 & 1 & 1 & 4 & 8 & 18 & 30 & 12 & 5 & 3 & 3 & 3 & 6 & 5 \\
\hline $\mathrm{EE}$ & 1.1 & 4 & 3 & 7 & 7 & 11 & 21 & 17 & 12 & 7 & 3 & 3 & 5 & 1 \\
\hline IE & 0.1 & 1 & 1 & 10 & 19 & 29 & 30 & 8 & 2 & 0 & 0 & 0 & 0 & 0 \\
\hline GR & 2.1 & 7 & 7 & 22 & 23 & 20 & 15 & 3 & 0 & 0 & 0 & 0 & 0 & 0 \\
\hline ES & 1.1 & 3 & 3 & 9 & 11 & 18 & 29 & 13 & 5 & 2 & 1 & 1 & 2 & 2 \\
\hline FR & 0.1 & 0 & 0 & 2 & 4 & 14 & 48 & 25 & 4 & 1 & 0 & 0 & 0 & 1 \\
\hline HR & 6.6 & 13 & 7 & 16 & 16 & 13 & 9 & 4 & 2 & 1 & 1 & 1 & 1 & 9 \\
\hline IT & 1.8 & 6 & 4 & 12 & 13 & 15 & 20 & 13 & 5 & 3 & 2 & 1 & 2 & 2 \\
\hline $\mathrm{CY}$ & 9.4 & 12 & 7 & 17 & 13 & 15 & 17 & 6 & 2 & 1 & 0 & 0 & 0 & 0 \\
\hline LV & 1.9 & 12 & 5 & 11 & 10 & 13 & 19 & 12 & 6 & 4 & 3 & 1 & 1 & 1 \\
\hline LT & 3.4 & 8 & 6 & 15 & 15 & 16 & 18 & 8 & 3 & 2 & 2 & 1 & 2 & 1 \\
\hline LU & 0.1 & 0 & 0 & 2 & 5 & 18 & 55 & 16 & 2 & 1 & 0 & 0 & 0 & 0 \\
\hline $\mathrm{HU}$ & 0.2 & 4 & 3 & 8 & 8 & 11 & 18 & 14 & 6 & 4 & 3 & 4 & 8 & 7 \\
\hline MT & 17.0 & 14 & 6 & 11 & 10 & 14 & 22 & 5 & 0 & 0 & 0 & 0 & 0 & 0 \\
\hline $\mathrm{NL}$ & 0.0 & 0 & 1 & 4 & 7 & 23 & 45 & 14 & 3 & 2 & 0 & 0 & 0 & 0 \\
\hline AT & 0.5 & 2 & 2 & 14 & 24 & 30 & 21 & 3 & 1 & 0 & 0 & 0 & 0 & 0 \\
\hline $\mathrm{PL}$ & 3.7 & 9 & 9 & 24 & 22 & 15 & 8 & 4 & 2 & 1 & 1 & 1 & 1 & 0 \\
\hline PT & 6.5 & 4 & 3 & 9 & 10 & 14 & 20 & 16 & 8 & 5 & 2 & 1 & 2 & 1 \\
\hline RO & 10.3 & 10 & 4 & 8 & 8 & 9 & 13 & 11 & 7 & 4 & 3 & 2 & 4 & 7 \\
\hline SI & 2.9 & 10 & 10 & 27 & 20 & 14 & 9 & 2 & 0 & 1 & 0 & 0 & 2 & 3 \\
\hline SK & 0.3 & 1 & 1 & 2 & 2 & 3 & 7 & 8 & 7 & 7 & 7 & 8 & 22 & 25 \\
\hline $\mathrm{FI}$ & 0.0 & 1 & 2 & 9 & 16 & 25 & 31 & 11 & 3 & 1 & 0 & 1 & 0 & 0 \\
\hline SE & 0.0 & 2 & 2 & 6 & 8 & 14 & 32 & 22 & 7 & 3 & 1 & 1 & 1 & 0 \\
\hline UK & 0.0 & 0 & 1 & 3 & 6 & 13 & 31 & 23 & 9 & 5 & 3 & 2 & 2 & 2 \\
\hline EU28 & 1.4 & 3 & 3 & 8 & 11 & 16 & 27 & 15 & 5 & 3 & 2 & 1 & 3 & 3 \\
\hline
\end{tabular}

Source: EC (2017b); adaptation by Wageningen Economic Research. 
Table B3.5 Family farm income (including direct CAP payments) per family work unit a) in EU member countries, 2015 (\% GDP per capita)

\begin{tabular}{|c|c|c|c|c|c|c|c|}
\hline & 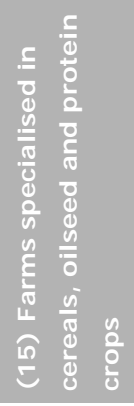 & 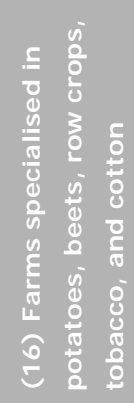 & 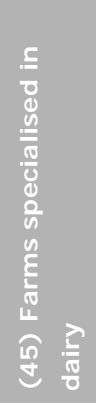 & 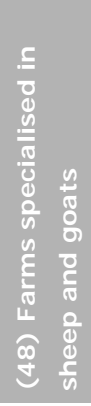 & 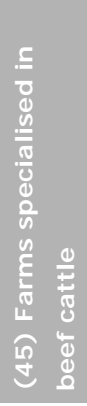 & 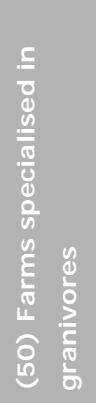 & $\begin{array}{l}\text { GDP per } \\
\text { capita (€) }\end{array}$ \\
\hline Belgium & . b) & 112 & 79 & . & 66 & 134 & 36,500 \\
\hline Cyprus & 66 & 109 & . & 51 & . & . & 20,900 \\
\hline Greece & 56 & 63 & . & 99 & 129 & 133 & 16,300 \\
\hline Spain & 79 & 103 & 117 & 121 & 65 & 253 & 23,300 \\
\hline Estonia & 147 & 64 & 23 & 24 & 32 & 137 & 15,500 \\
\hline France & 44 & 121 & 58 & 53 & 60 & 70 & 33,000 \\
\hline Hungary & 292 & 207 & 173 & 88 & 163 & 191 & 11,300 \\
\hline Ireland & 84 & . & 92 & 18 & 28 & . & 56,400 \\
\hline Italy & 79 & 107 & 210 & 102 & 121 & 484 & 27,200 \\
\hline Lithuania & 161 & 66 & 39 & . & 71 & 31 & 12,900 \\
\hline Portugal & 121 & 83 & 125 & 64 & 97 & 167 & 17,400 \\
\hline Finland & 25 & 41 & 45 & . & 63 & 80 & 38,200 \\
\hline Sweden & 4 & 42 & 74 & -38 & 33 & 106 & 45,800 \\
\hline Slovakia & 70 & -69 & 208 & 459 & 822 & . & 14,600 \\
\hline Slovenia & 7 & 12 & 31 & 27 & 14 & 90 & 18,800 \\
\hline United Kingdom & 60 & 122 & 65 & 49 & 31 & 158 & 40,000 \\
\hline Bulgaria & 273 & 151 & 89 & 79 & 52 & 34 & 6,300 \\
\hline Romania & 117 & 42 & 39 & 56 & 28 & 64 & 8,100 \\
\hline Croatia & 59 & 69 & 57 & 47 & 31 & 65 & 10,600 \\
\hline EU28 & 51 & 58 & 51 & 42 & 45 & 112 & 29,000 \\
\hline
\end{tabular}

a) FADN variable SE430: Family farm income per family work unit; b) A dot in a cell indicates that, due to insufficient observations, no information for the relevant group can be shown; c) A negative agricultural income indicates that the costs associated with agricultural production are higher than its revenues.

Source: FADN and Eurostat; adaptation by Wageningen Economic Research. 
Table B3.6 Direct CAP payments for each family work unit in EU member countries, 2015 (€)

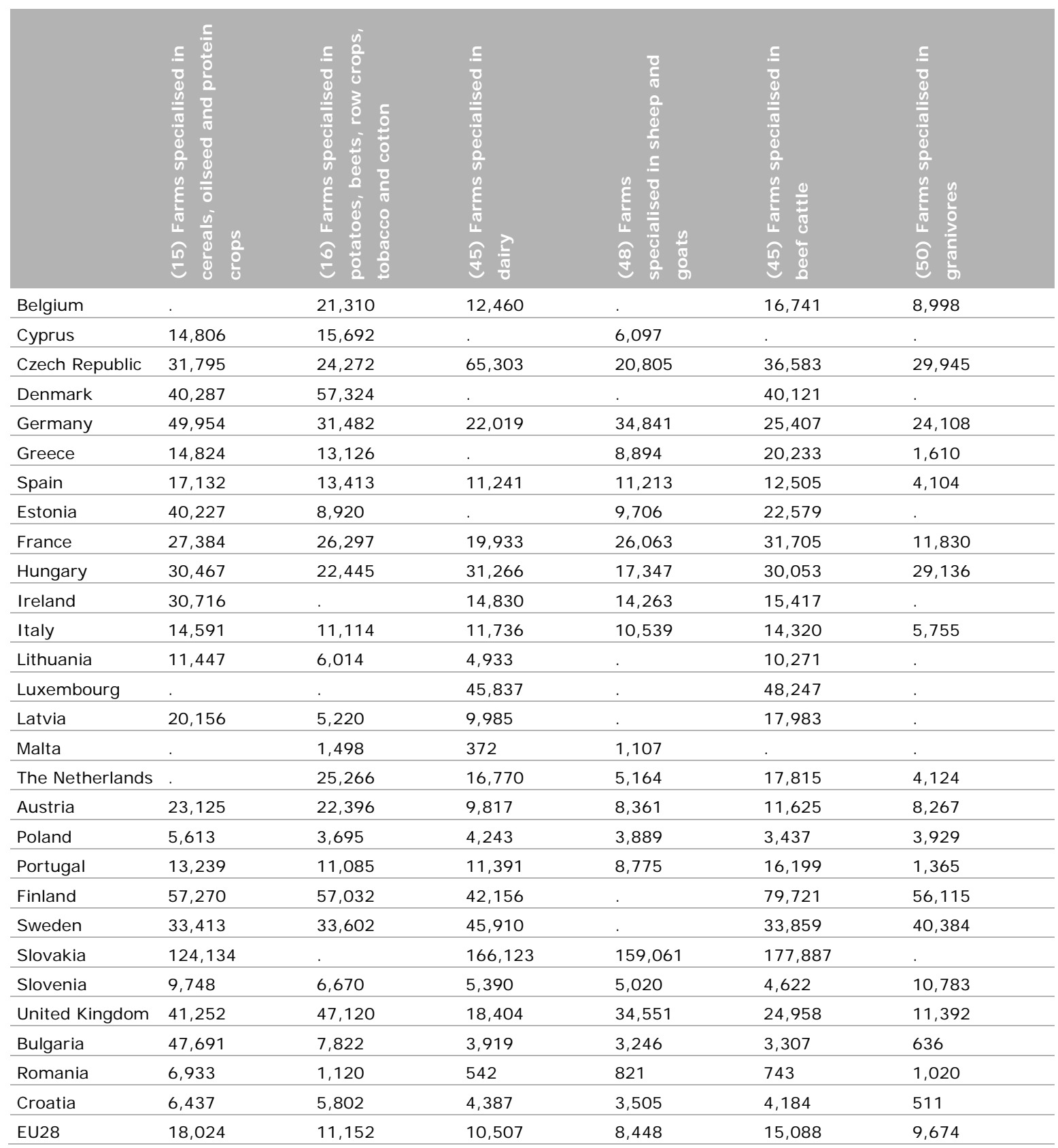

A dot in a cell indicates that no information for the relevant group can be shown due to insufficient observations.

Source: FADN; adaptation by Wageningen Economic Research. 
Table B3.7 Direct CAP payments as a percentage of family farm income per family work unit in EU member countries, $2015(€)$

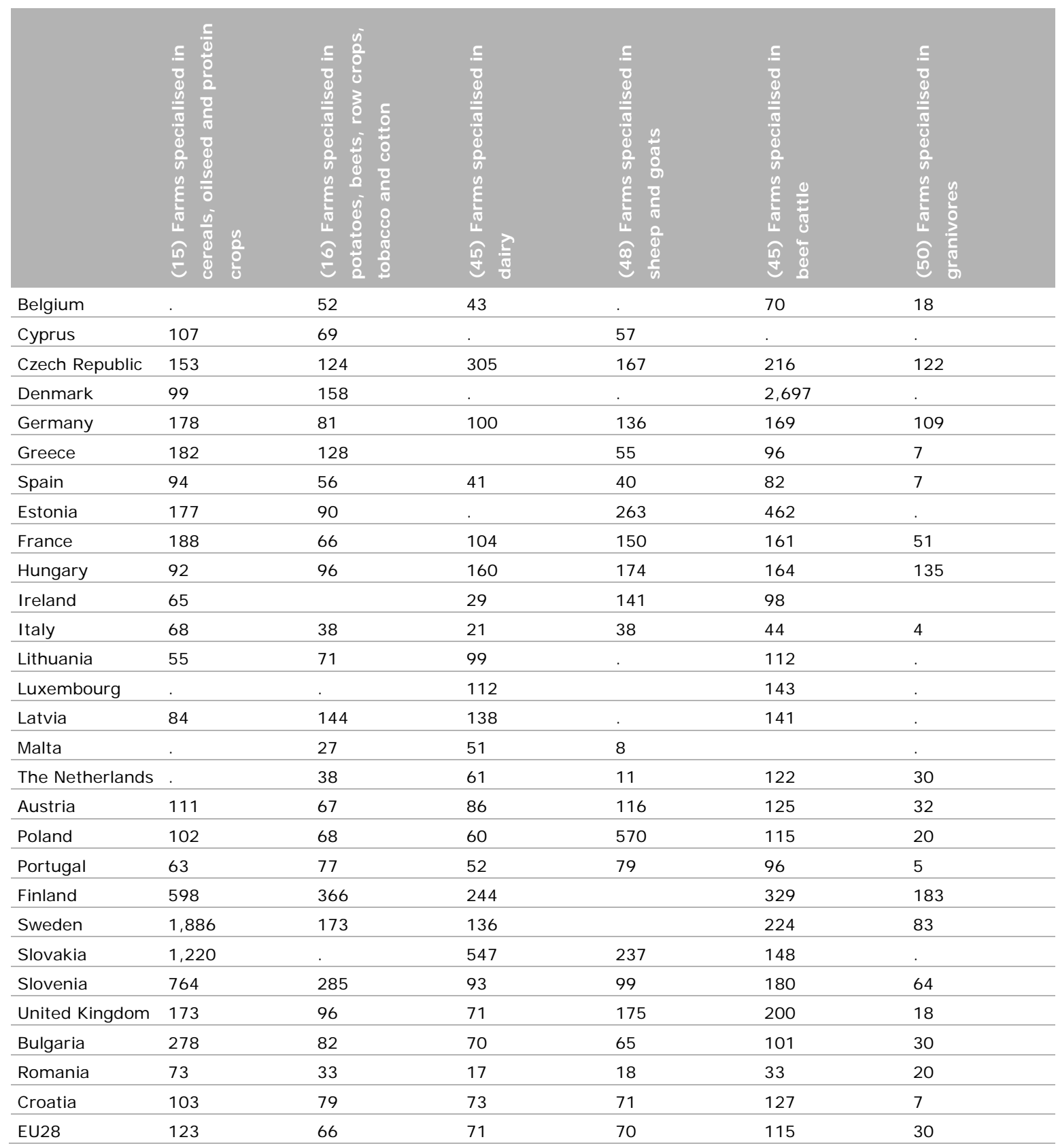

A dot in a cell indicates that no information for the relevant group can be shown due to insufficient observations.

Source: FADN; adaptation by Wageningen Economic Research. 
Table B3.8 Family farm income (excluding direct CAP payments) per family work unit by business type in EU member countries, 2015 (\% GDP per capita)

\begin{tabular}{|c|c|c|c|c|c|c|c|}
\hline & 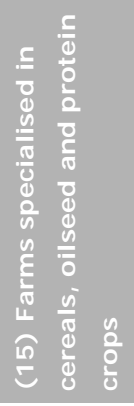 & 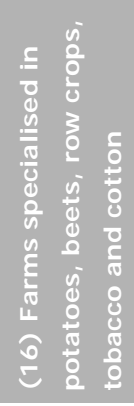 & 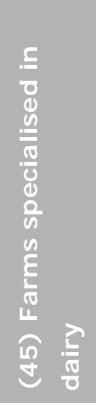 & 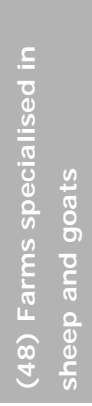 & 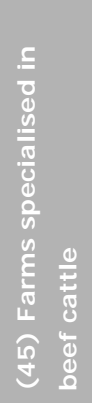 & 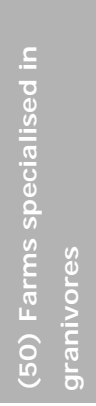 & $\begin{array}{l}\text { GDP per } \\
\text { capita (€) }\end{array}$ \\
\hline Belgium & . & 54 & 45 & . & 20 & 109 & 36,500 \\
\hline Cyprus & -5 & 34 & . & 22 & & . & 20,900 \\
\hline Greece & -35 & -18 & . & 44 & 5 & 123 & 16,300 \\
\hline Spain & 5 & 45 & 69 & 73 & 11 & 235 & 23,300 \\
\hline Estonia & -113 & 6 & & -39 & -114 & & 15,500 \\
\hline France & -39 & 41 & -3 & -26 & -36 & 34 & 33,000 \\
\hline Hungary & 23 & 9 & -103 & -65 & -103 & -67 & 11,300 \\
\hline Ireland & 29 & . & 65 & -7 & . & & 56,400 \\
\hline Italy & 25 & 66 & 167 & 63 & 68 & 463 & 27,200 \\
\hline Lithuania & 72 & 19 & . & . & -9 & . & 12,900 \\
\hline Portugal & 45 & 19 & 60 & 13 & 4 & 159 & 17,400 \\
\hline Finland & -125 & -109 & -65 & . & -145 & -67 & 38,200 \\
\hline Sweden & -69 & -31 & -27 & . & -41 & 18 & 45,800 \\
\hline Slovakia & -781 & . & -930 & -630 & -396 & 0 & 14,600 \\
\hline Slovenia & -45 & -23 & 2 & . & -11 & 33 & 18,800 \\
\hline United Kingdom & -44 & 5 & 19 & -37 & -31 & 130 & 40,000 \\
\hline Bulgaria & -484 & 27 & 27 & 28 & & 24 & 6,300 \\
\hline Romania & 31 & 28 & 32 & 46 & 19 & 51 & 8,100 \\
\hline Croatia & -2 & 14 & 15 & 14 & -8 & 60 & 10,600 \\
\hline EU28 & -11 & 20 & 15 & 13 & -7 & 78 & 29,000 \\
\hline
\end{tabular}

A dot in a cell indicates that no information for the relevant group can be shown due to insufficient observations.

A negative agricultural income indicates that the expenses associated with agricultural production are higher than its yields.

Source: FADN and Eurostat; adaptation by Wageningen Economic Research. 
Wageningen Economic Research P.O. Box 29703

2502 LS The Hague

The Netherlands

T +31 (0)70 3358330

E communications.ssg@wur.nl

www.wur.eu/economic-research

Wageningen Economic Research REPORT

2018-039
The mission of Wageningen University and Research is "To explore the potential of nature to improve the quality of life". Under the banner Wageningen University \& Research, Wageningen University and the specialised research institutes of the Wageningen Research Foundation have joined forces in contributing to finding solutions to important questions in the domain of healthy food and living environment. With its roughly 30 branches, 5,000 employees and 10,000 students, Wageningen University \& Research is one of the leading organisations in its domain. The unique Wageningen approach lies in its integrated approach to issues and the collaboration between different disciplines. 



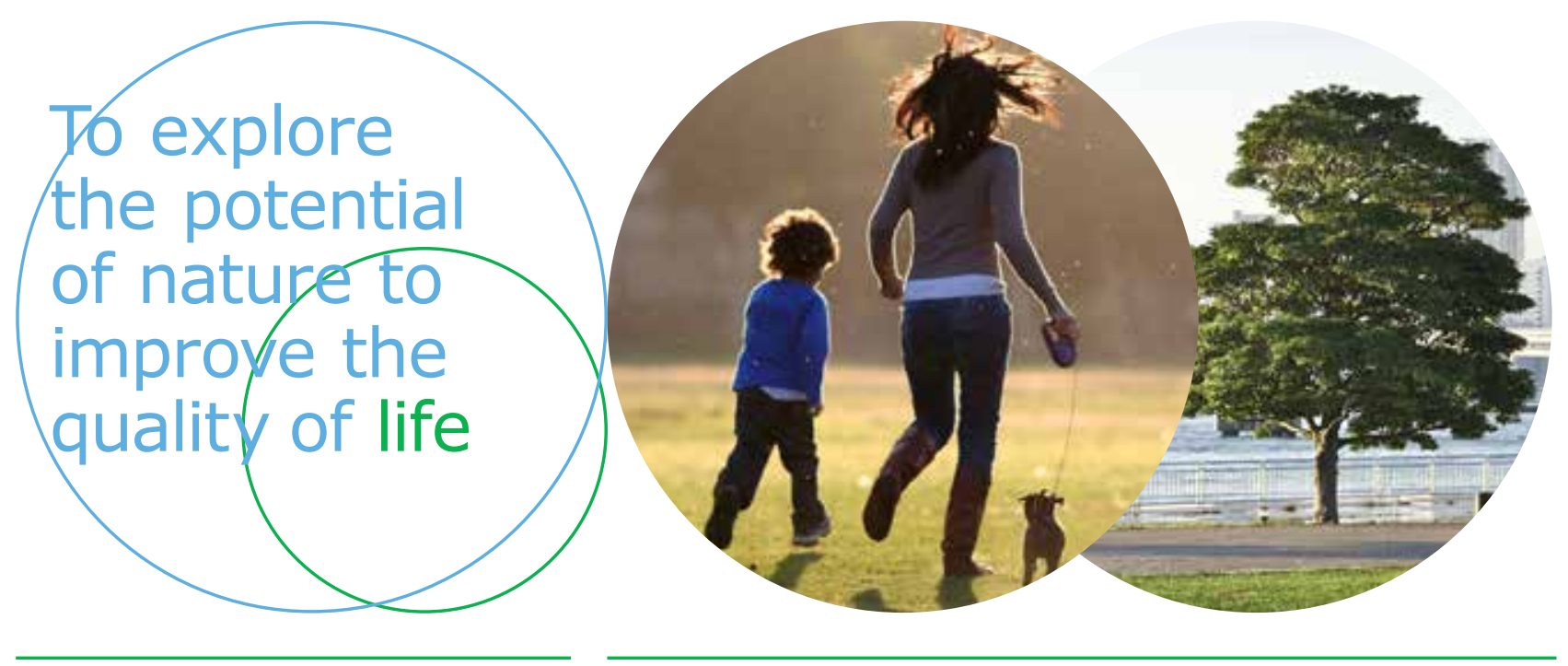

Wageningen Economic Research P.O. Box 29703

2502 LS Den Haag

The Netherlands

E communications.ssg@wur.nl

www.wur.eu/economic-research

Report 2018-039b

ISBN 978-94-6343-266-5
The mission of Wageningen University and Research is "To explore the potential of nature to improve the quality of life". Under the banner Wageningen University \& Research, Wageningen University and the specialised research institutes of the Wageningen Research Foundation have joined forces in contributing to finding solutions to important questions in the domain of healthy food and living environment. With its roughly 30 branches, 5,000 employees and 10,000 students, Wageningen University \& Research is one of the leading organisations in its domain. The unique Wageningen approach lies in its integrated approach to issues and the collaboration between different disciplines. 